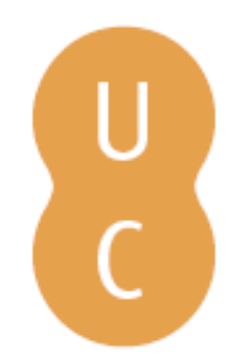

\title{
nommalina
}

\section{Um doce e nutritivo fruto: a castanha na história da alimentação e da gastronomia portuguesas}
Autor(es):
Coelho, Maria Helena da Cruz; Soares, Carmen
Publicado por: Imprensa da Universidade de Coimbra
URL
persistente:
URI:http://hdl.handle.net/10316.2/45246
DOI:
DOI:https://doi.org/10.14195/978-989-26-1720-6_6
Accessed : $\quad$ 26-Apr-2023 08:25:05

A navegação consulta e descarregamento dos títulos inseridos nas Bibliotecas Digitais UC Digitalis, UC Pombalina e UC Impactum, pressupõem a aceitação plena e sem reservas dos Termos e Condições de Uso destas Bibliotecas Digitais, disponíveis em https://digitalis.uc.pt/pt-pt/termos.

Conforme exposto nos referidos Termos e Condições de Uso, o descarregamento de títulos de acesso restrito requer uma licença válida de autorização devendo o utilizador aceder ao(s) documento(s) a partir de um endereço de IP da instituição detentora da supramencionada licença.

Ao utilizador é apenas permitido o descarregamento para uso pessoal, pelo que o emprego do(s) título(s) descarregado(s) para outro fim, designadamente comercial, carece de autorização do respetivo autor ou editor da obra.

Na medida em que todas as obras da UC Digitalis se encontram protegidas pelo Código do Direito de Autor e Direitos Conexos e demais legislação aplicável, toda a cópia, parcial ou total, deste documento, nos casos em que é legalmente admitida, deverá conter ou fazer-se acompanhar por este aviso.

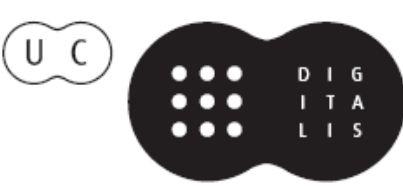


Carmen Soares

\section{Cilene da Silva Gomes Ribeiro}

\section{(coords.)}

MESAS

\section{ALIMENTAÇÃ O, SAÚDE \& CULTURA}

\section{IU LUO-BRASILEIRAS}

\section{VOLUME II}

IMPRENSA DA UNIVERSIDADE DE COIMBRA

COIMBRA UNIVERSITY PRESS

PUCPRESS 


\title{
UM DOCE E NUTRITIVO FRUTO: A CASTANHA NA HISTÓRIA DA ALIMENTAÇÃO E DA GASTRONOMIA PORTUGUESAS
}

\author{
(A sweet and nutritious fruit: the chestnut in the \\ history of Portuguese food and gastronomy)
}

\author{
Maria Helena da Cruz Coelho \\ Universidade de Coimbra \\ Centro de História da Sociedade e da Cultura \\ COELHOMH@GMAIL.COM \\ Carmen Soares \\ Universidade de Coimbra \\ Centro de Estudos Clássicos e Humanísticos \\ da Universidade de Coimbra" \\ CILSOARES@GMAIL.COM
}

RESUMO: No presente estudo faz-se a história comparada da castanha na alimentação e gastronomia portuguesas na longa duração. As fontes consideradas, na sua maioria escritas (tanto literárias, como documentais e técnicas), cobrem cerca de 26 séculos, da Antiguidade clássica, atravessando os espaços europeus historicamente ligados ao cultivo e aproveitamento da castanha, até ao Portugal contemporâneo. O vasto universo de materiais disponíveis obrigou ao estabelecimento de critérios precisos de seleção das fontes, condicionados pelo objetivo principal do estudo: estabelecer a pegada literária da castanha. Assim, o foco da análise recaiu sobre testemunhos escritos sobre o uso da castanha na alimentação humana, buscando para cada época a tipologia de textos mais abundante em termos informativos: para a Antiguidade, textos literários e médicos gregos e romanos; para a Idade Média, documentação régia circunscrita sobretudo ao séc. XIII; para as Épocas Moderna e Contemporânea, os manuscritos, livros e revistas culinárias. A estrutura do trabalho reflete as principais conclusões alcançadas: a castanha como fruto básico da alimentação de populações específicas e consumido em contextos de carência, em que funciona como substituto do alimento primordial, o pão (ponto 1: A castanha, um alimento de sobrevivência); a castanha como património gastronómico, moldado pelas preocupações dietéticas (ponto 2: A castanha, um prazer da mesa em diálogo com as normas dietéticas; ponto 2.1: Consumo da castanha no Portugal moderno, gastronomia e dietética); a cultura, o consumo e as conceções gastronómicas e dietéticas associadas à castanha

"Trabalho desenvolvido no âmbito do projeto UID/HIS/00311/2013, financiado pela FCT - Fundação para a Ciência e a Tecnologia.

"Trabalho desenvolvido no âmbito do projeto UID/ELT/00196/2013, financiado pela FCT - Fundação para a Ciência e a Tecnologia. 
para Portugal têm raízes em tempos anteriores à fundação da nacionalidade (ponto 1.1: Cultura e consumo de castanha na Antiguidade: herança clássica e realidade portuguesa); a identificação de um "receituário fundador" da castanha nos primeiros tempos da nacionalidade (ponto 1.2: Cultura e consumo de castanha no Portugal medieval); a castanha como ingrediente transversal tanto à cozinha tradicional portuguesa como à cozinha requintada de influência e inspiração estrangeira (ponto 2. 2: Consumo de castanha no Portugal contemporâneo: da "alta cozinha" à cozinha tradicional portuguesa).

Palavras-Chave: castanha, história da alimentação, gastronomia, Portugal, literatura culinária.

ABSTRACT: This study analyses the role played by the chestnut in the history of Portuguese food and gastronomy. The research is based mainly on written sources (literature, historical documents and technical texts), covering 26 centuries, from antiquity to modern times, related not only to Portugal but also to other European countries where the sweet chestnut grows and its fruit is used in food. Given the huge quantity of data on the subject, our research focuses on what may be called the "literary footprint" of the chestnut in human diet, concentrating, for each historical period, on the most revealing categories of source material: literature and medical writings for Greek and Roman antiquity; royal documentation, mainly written in the 13th Century, for medieval times; culinary manuscripts, books and journals for modern and contemporary periods. The paper is structured in accordance with our conclusions: the chestnut has been a staple food for specific communities and in famine contexts, acting as a substitute ingredient for bread, the staple food par excellence (cf. section 1: The chestnut, a survival food); the chestnut constitutes a gastronomic heritage shaped throughout history by dietetics (cf. section 2: The chestnut, a culinary pleasure shaped by dietetics; section 2.1: Chestnut consumption in Portugal during the modern era: gastronomy and dietetics); in Portugal chestnut cultivation, its consumption as fruit and gastronomic and dietetic ideas on the subject go back to antiquity (cf. section 1.1: Chestnut cultivation and consumption in antiquity: classical heritage and Portuguese reality); the constitution of "founding recipes" for chestnuts during the early days of Portuguese history (cf. section 1.2: Chestnut cultivation and consumption in Portugal during the medieval era); the chestnut is a common ingredient in traditional Portuguese cookery and also in more elaborate cuisine under foreign inspiration and influence (cf. section 2.2: Chestnut consumption in Portugal during modern times: from haute cuisine to traditional Portuguese cuisine).

KEYWORDS: chestnut, history of food, gastronomy, Portugal, culinary literature. 
As castanhas são encaradas pela maioria dos consumidores portugueses como um fruto sazonal, ligado a festividades de colorido etnográfico (as "castanhadas" e as várias "feiras da castanha") ${ }^{1}$. Têm também expressão própria na cozinha tradicional, associada às principais regiões produtoras. Mais recentemente tem-se vindo de igual modo a assistir à ascensão das castanhas ao patamar da cozinha gourmet e dos produtos saudáveis². Aliás, como muitas vezes sucede, em Portugal, o setor de produção e comercialização do fruto e seus transformados seguiu, também neste campo, uma via primeiro encetada por outros países europeus e asiáticos ${ }^{3}$.

Perante este panorama, ao historiador coloca-se a questão de saber de que forma evoluiu o consumo de um fruto para o qual hoje se reconhecem as valências de alimento tradicional, típico (associado a determinado território ${ }^{4}$, gourmet e saudável. Fazer um estudo sobre a história da castanha na alimentação e gastronomia portuguesas, numa perspetiva temática, diacrónica e comparativa com outras espacialidades e práticas, impõe uma definição clara e prévia dos pressupostos teóricos, dos objetivos, das fontes e das metodologias de pesquisa adotados.

Legitimado o seu estatuto de objeto científico da História, em 1961, com o inaugural e (hoje) clássico estudo de Fernand Braudel "Alimentation et catégories de 1'histoire", o alimento tem sido alvo de um cada vez mais complexo escrutínio do seu valor na história da humanidade. Resumem-se a quatro essas expressões de valor e utilidade dos produtos que servem de comida: alimentação, gastronomia, medicina e património. Ou seja, o ser humano consome alimentos para se manter vivo (daí a propriedade de se lhes chamar "mantimentos"): esta é a vertente "alimentar" reconhecida à ingestão de comida. Mas, sempre que lhe assiste a opção de escolha, o consumidor não se limita a buscar sustento, antes elege os alimentos de acordo com o prazer

$1 \quad \mathrm{Na}$ década de 80 do século passado, o crítico gastronómico José Quitério (1987: 281), numa das suas crónicas, sublinhava que as castanhas estavam, no geral, confinadas a um reduto etnográfico: "Com o desenvolvimento económico, e pelo reflexo condicionado que tende a varrer do quotidiano quaisquer símbolos de um passado indigente, as castanhas viram-se limitadas a uma função quase etnográfica de alimentos rituais em festividades cíclicas. Pode ser que com a voga do retorno ao "natural" voltem a suscitar o interesse alimentar que merecem".

2 Sobre os benefícios para a saúde do consumo de castanha crua ou processada manual e industrialmente, vd. Vasconcelos et al. (2010).

Vd. Cardoso, Pereira (2007: 35): "Mas ao contrário do que aconteceu em Portugal, onde a castanha se tornou um produto pouco qualificado, outros países da Europa (Itália, França e Espanha) e da Ásia (Japão, Coreia e China) diversificaram o aproveitamento destes frutos, surgindo no mercado actual, após transformação (purés, compotas, castanhas em calda, castanhas com chocolate, "souflés", conservas, rebuçados, iogurtes, bolos, aperitivos, gelados, etc.), com significativa e crescente aceitação".

Sobre o conceito de "típico" enquanto construção que liga diretamente a determinado território (local, nacional ou colonial) um produto com as suas respetivas características de produção, vd. Ceccarelli et al. (2010). 
(sensorial e intelectivo) associado à comida: essa é a valência "gastronómica" da alimentação. Outra condicionante (auto ou hétero sugerida) diz respeito à interferência da alimentação na saúde de quem come, o que corresponde à valência "dietética" dos alimentos. De forma mais ou menos consciente, o ato de se alimentar resulta de e busca rememorar práticas herdadas dos antecessores (aqueles que em latim genericamente se denominavam de patres). Estamos, neste caso, perante a valia "patrimonial" da alimentação, que encerra em si o mais abrangente sentido identitário dos alimentos 5 .

Uma análise holística da alimentação enquanto objeto de história deve, por conseguinte, dar conta não só da forma como essas valências se entretecem umas com as outras (complementando-se ou conflituando entre si), mas também como inevitavelmente se encontram no denominador comum que é a cultura. Produto das artes/técnicas do conhecimento humano, as diversas atividades de sustento, fruição, terapia e comemoração envolvendo alimentos são todas processos culturais. Como processos que são, estão em constante "movimento", sendo possível ao historiador analisar nas fontes a evolução diacrónica por que passam. No estudo realizado, recorremos maioritariamente a documentação escrita, de tipologia diversa, de acordo com os materiais mais pertinentes disponíveis para cada época. Assim, para a Antiguidade (cultura que influenciou o padrão alimentar das regiões colonizadas por Gregos e Romanos, logo Portugal), tivemos em conta fontes literárias e tratados médicos. Alguma informação obtida por estudos recentes de arqueobotânica foi também usada, pela relevância que tem em matéria do consumo de castanha no Portugal romano, território para o qual não existem fontes escritas da época. No referente à Idade Média, o recorte das fontes incidiu com maior detalhe sobre as inquirições de 1220 e documentação da chancelaria régia. Para a Época Moderna baseámo-nos em manuscritos (entretanto publicados) e livros de cozinha, tendo recorrido, pontualmente, ao cruzamento com a literatura médica. No que se refere às fontes dos sécs. XX e XXI, focámo-nos em livros e revistas de culinária.

Aplicando ao estudo da castanha a "ficha de leitura" acima identificada para as valências operativas fundamentais dos alimentos, procedemos ao estabelecimento de duas linhas de análise. Esta autonomização temática foi adotada apenas para tornar mais evidente como as fontes (sobretudo as escritas, na medida em que nelas se pode vislumbrar a "voz" autoral) refletem o predomínio de determinado foco interpretativo sobre outros. Importa, no entanto, ter bem presente que a distinção entre alimento-comida e alimento-medicamento, responsável por uma dissociação da medicina em relação ao

Sobre o entendimento da alimentação como fator identitário ou de identificação, expressão cultural e "bem" patrimonial, vd. Fischler (1988), Scholliers (2001), Bruegel-Laurioux (2002), Montanari (2004), Bessière-Tibère (2011) e Greyzen (2014). 
universo culinário, só muito tardiamente se deu. $\mathrm{Na}$ verdade, enquanto o modelo dietético de matriz hipocrático-galénica perdurou na Europa (até ao séc. XVIII), a comida era concebida como um universo que congregava as funções de alimentar (ou nutrir) e de dar prazer, ambas filtradas pela dimensão médica ${ }^{6}$. Ou seja, o tratamento que damos às duas grandes valências da castanha em rubricas autonomizadas visa apenas relevar testemunhos que atestem cada uma das funções e não significa que advoguemos que historicamente constituíram campos com fronteiras rígidas. Dentro de cada rubrica seguiremos uma linha cronológica de análise, a qual visa sublinhar permanências e transformações nessa longa duração, o que, necessariamente, leva a retomar determinados aspetos em momentos diversos da análise ${ }^{7}$.

\section{A castanha: um alimento de sobrevivência}

Comecemos este apartado por reconhecer, juntamente com Conedera et al. $(2004)^{8}$, como a falta de estudos paleobotânicos e arqueológicos e as parcas referências documentais e literárias escritas dificultam o nosso conhecimento sobre o cultivo do castanheiro e os usos do seu fruto para os períodos anteriores à Idade Média. Ainda assim, a matriz greco-romana da cultura portuguesa impõe que se proceda à análise de documentação (material e escrita) capaz de permitir reconstituir, dentro dos limites inerentes à própria escassez e ao caráter indireto das fontes, a história da castanha para tempos anteriores à fundação da nacionalidade portuguesa ${ }^{9}$.

\section{i.i. Cultura e consumo de castanha na Antiguidade: herança CLÁSSICA E REALIDADE PORTUGUESA}

Antes de atentarmos nos testemunhos sobre o consumo do fruto, importa, ainda que de forma muito breve, sintetizar a origem e dispersão geográficas, bem como a evolução genética por que passou o castanheiro. O centro de irradiação da espécie progenitora (Castanea mollissima Blume) situam-no os especialistas na China, com presença atestada para Portugal durante a

\footnotetext{
6 Desenvolveremos esta questão adiante, na abertura do ponto 2.

7 As autoras procederam a uma repartição do tratamento das fontes, tendo ficado os materiais da Idade Média a cargo de Maria Helena da Cruz Coelho e os restantes a cargo de Carmen Soares.

8 Os autores deste estudo têm por isso o cuidado de explicar que, não obstante as conclusões a que chegaram careçam de análises em maior extensão da problemática do cultivo da castanha e sua difusão à escala europeia, utilizam pela primeira vez uma abordagem multidisciplinar, que combina os estudos paleobotânicos e palinológicos com a arqueologia, a história e a literatura.

Para um levantamento das fontes escritas clássicas mais relevantes nesta matéria, vd. André (1961: 84-85); García Soler (2001: 121) e Dalby (2003: sub verbum Chestnut).
} 
idade do Mioceno (há c. de 15 milhões de anos) ${ }^{10}$. Dessa espécie derivou o castanheiro europeu, produtor de castanha doce (Castanea sativa Mill.), bem implantado na Grécia e nas suas áreas de colonização (nomeadamente na península itálica e Sicília, na Antiguidade conhecidas por Magna Grécia) à volta de 3000 a.C. Sabe-se que o impulso globalizante dos colonizadores romanos foi decisivo para a difusão do cultivo dessa espécie pelos vários territórios europeus conquistados. Não dispomos, no entanto, de informação suficiente para "responsabilizar" a ação civilizadora romana pela prática sistemática do plantio de soutos e do uso normalizado do seu fruto na alimentação de determinadas populações. Teremos de esperar pela Idade Média para, com segurança, afirmar que essa sistematização se deu, ou seja que a "ideia" plantada pelos Romanos - de cultivo e exploração intensiva das mais diversas árvores de fruto (domesticadas) - frutificou, traduzindo-se, no caso concreto da castanha, na sua transformação em cultura (agrícola-florestal) de subsistência ${ }^{11}$. $\mathrm{O}$ estudo por nós mais aprofundado para a realidade portuguesa permite, como veremos, concordar com os resultados obtidos para outras culturas europeias, igualmente influenciadas pelas civilizações clássicas.

A documentação relativa à antiguidade greco-romana leva-nos a perceber que há muito de continuum histórico entre o Portugal medieval e os tempos que o precederam. Mais, confirma-se que, do ponto vista da construção de um património cultural do consumo da castanha (como da generalidade dos produtos da alimentação portuguesa), é indispensável recuar às matrizes clássicas e não iniciar ex abrupto a história da alimentação com a fundação da nacionalidade.

$\mathrm{O}$ que os testemunhos mais antigos para o consumo e cultivo de castanha doce no Mediterrâneo helenizado atestam é que se tratava de uma espécie de planta natural de regiões montanhosas, tanto autóctones ao mundo grego, como externas. Mais, o fruto terá tido uma introdução posterior a outros, como a bolota e a noz, pois, antes do aparecimento das denominações gregas kastáneion e kástanon (de que deriva o nome latino castanea), usavam-se para nomeá-lo expressões compostas pela junção dos nomes daqueles dois outros frutos, então já bem ambientados e comuns, a um adjetivo topográfico (denunciador da respetiva proveniência). Ou seja, os nomes mais antigos para "castanha" foram: "noz de Eubeia" (káryon Euboikón) e "noz de Caristo" (káryon Karýstion) - remetendo respetivamente para a grande ilha grega de Eubeia e para uma das suas cidades; "noz/bolota de Sardes" (káryon Sardianón/Sardianè bálanos) - aludindo à capital do reino da Lídia, na Ásia Menor.

10 Vd. Abreu (2007), estudo em que se procede a um "estado da arte" da questão e em que se localiza (p. 18) o mais antigo testemunho em território nacional em Canha (Montijo).

11 Comungamos da proposta de análise avançada por Conedera et al. (2004) sobre o contributo da civilização romana para o desenvolvimento do plantio de castanheiro e consumo do seu fruto. 
Repare-se que a própria denominação latina para o fruto, i.e. castanea, etimologicamente derivada do grego, é uma evidência indireta da origem helénica do desenvolvimento de técnicas do cultivo da castanha entre os latinos. Essa hipótese de transmissão cultural ganha mais sentido, se se tiver em linha de conta que, como alertam Conedera et al. (2004: 168-169), a implantação geográfica da planta vem associada pelos textos latinos a regiões colonizadas pelos Gregos, sitas na Magna Grécia. Vejam-se as variedades elencadas por Plínio-o-Velho (tarantina, da cidade de Tarento; corelliana e tereiana, localidades nos arredores de Nápoles) ${ }^{12}$ e o elogio de Ovídio ao plantio de castanheiros nas encostas do Monte Etna (na Sicília) ${ }^{13}$.

Se juntarmos a este estudo linguístico, informações dadas sobre a corografia adequada ao castanheiro, constatamos ser verdadeira para a realidade clássica, como para períodos históricos posteriores, a adequação natural dos terrenos montanhosos à sua produção. Naquele que é o primeiro tratado grego de botânica, a História das plantas, da autoria de Teofrasto (IV-III a.C.), discípulo de Aristóteles, verifica-se a inclusão do castanheiro entre as árvores naturais de lugares montanhosos. Do mundo grego refere a já aludida ilha de Eubeia e dois montes bem conhecidos da Ásia Menor (atual Turquia), o Tmolo e o Olimpo Mísio, além da região que se dava pelo nome de Magnésia, em cuja proximidade se situa um local cuja toponímia moderna turca confirma essa forte implantação da árvore e respetivo fruto, precisamente chamada Kestané-dagh ("monte dos castanheiros") ${ }^{14}$.

A preponderância do produto na economia e subsistência das populações das zonas montanhosas, atestada de forma mais segura da Idade Média em diante, autorizou a que, como alerta Gabrielli (1994) ${ }^{15}$, essas sociedades ficassem conhecidas como "civilizações da castanha". Ainda que não tenha desempenhado o papel de mantimento de subsistência no contexto alimentar das culturas grega e romana, onde aos cereais cabia esse estatuto de alimento primordial, é certo que a castanha foi considerada um alimento típico das mesas rústicas das populações das zonas montanhosas, em particular dos pastores. Esta associação, indubitavelmente, indicia o papel de destaque que, em contextos de maior produtividade/disponibilidade do fruto e concomitante falta de outros produtos básicos (como os já referidos cereais), a castanha assumiu na dieta das populações das montanhas, mesmo durante essas cronologias ${ }^{16}$.

12 Plínio-o-Velho (I d.C.), História natural 15: 93. Também Marcial, poeta epigramista do séc. I d.C., imortalizará as castanhas produzidas na região de Nápoles (Epigramas V. 78, V.14), fonte que retomaremos a propósito da técnica culinária de as assar.

Ovídio (I a.C.-I d.C.), Metamorfoses 3: 808-869.

Cf. Teofrasto, História das plantas 4.5.4 (Silva 2016: 185; Amigues 1989: 235, n. 14).

Apud Conedera et al. 2004: 161.

16 Uma vez que o foco da nossa análise é o fruto e não a árvore, não nos ativemos à numerosa informação de ordem agrícola e botânica, contida nas fontes clássicas pós-Era Cristã. 
Exemplo bastante ilustrativo dessa realidade, até porque acentua o papel do fruto enquanto sustento e dá informações sobre a sua valência dietética, chega-nos pela mão do médico de origem grega, natural de Pérgamo, mas vivendo e exercendo grande parte da sua carreira em Roma (onde terá integrado a corte do imperador Marco Aurélio), Galeno (c. 129-216 d.C.) ${ }^{17}$. É no livro II do seu tratado As faculdades dos alimentos que encontramos a menção à castanha, incluída num capítulo dedicado aos frutos silvestres, com destaque para a bolota ${ }^{18}$. Aí se dá conta de que, em contextos de fome e simultânea abundância de frutos habitualmente usados na alimentação dos porcos, a população das zonas rurais usa-os como substitutos alimentares dos cereais. $\mathrm{O}$ autor tem consciência de que, num estádio de civilização anterior à generalização no Mundo Grego do cultivo de cereais, e, depois desse, em determinadas regiões montanhosas (de que menciona a Arcádia), esses frutos silvestres serviram de sustento às populações. Em termos de hierarquização dos referidos frutos, cabe precisamente às castanhas a prerrogativa de serem as eleitas, pelo que as qualifica de "as melhores... das bolotas" (gr. áristai... tôn balánon). Para essa distinção terá também contribuído o facto de serem, pelo menos a espécie em causa, de todas as congéneres, as mais fáceis de remover a pele, uma vez que Galeno refere que havia quem as denominasse de lópimoi ("fáceis de pelar").

Em termos dietéticos, Galeno faz referência ao seu alto teor nutritivo, não obstante serem de "difícil cozedura" (gr. dúspeptos), ou seja de natureza indigesta - caracterização que perdurará em escritos médicos posteriores ${ }^{19}$, como mais adiante sublinharemos. Também há menções aos métodos de preparação culinária, que se começa por dizer serem muito variados. Especifica-se, no entanto, a cozedura em água e a posterior cozedura moderada das papas, daí resultantes, sob a cinza. Um outro preparado é a sopa (gr. etnos) ou caldo (que tem por base a cozedura em água), para o qual se discriminam quatro receitas: uma mais simples, feita com a farinha obtida dos frutos muito bem

Esse levantamento e análise encontra-se no estudo de Conedera et al. (2004: 173-174), onde se referem obras de Varrão (II-I a.C.), Columela (I d.C.), Plínio-o-Velho (I d.C.), Gargílio Marcial (III d.C.), Paládio (IV-V d.C.) e Cassiodoro (V-VI d.C.).

17 Sobre a vida e carreira de Galeno, vd. Nutton (2004: 216-229).

18 Não havendo até à data tradução portuguesa, remetemos para a obra e estudo de Powell (2003: 97-98), para a leitura do cap. 38, a que nos referimos.

19 Desde logo no tratado médico árabe do século XI, Tacuinum Sanitatis de Ibn Butlan, obra muito copiada e divulgada em finais da Idade Média, que segue a teoria hipocrático-galénica dos quatro humores. Aí escrevia-se que a castanha, quanto à sua natureza, era quente e seca. Dadas estas qualidades, e de acordo com a citada doutrina, tinha benefícios e malefícios para a saúde. Assim, se do ponto de vista alimentar era muito nutritiva, no reverso fazia inchar o organismo e provocava dores de cabeça, pelo que, para minorar esses males, o tratadista aconselhasse a cozê-la em água, como se especifica no manuscrito de Rouen do referido tratado, copiado talvez nos inícios de 1400 (Arano 1976: 43-45). 
moídos; outra em que se adicione a esse caldo temperos (indiscriminados); uma versão doce, a que se junta mel; e outra a que se adiciona leite à cocção.

Não há, porém, como ignorar que, antes de Galeno, outros médicos gregos, figuras externas ao ciclo dos redatores do grande núcleo de tratados atribuídos à Escola Hipocrática (conhecida pela redação do chamado Corpus Hippocraticum), devem ser tidos em conta numa "leitura médica" do uso da castanha na alimentação. O grande transmissor de fragmentos desses textos, de que não sobreviveu nenhuma versão completa, foi Ateneu de Náucrates (II-III d.C. ${ }^{20}$. Dele nos valemos para apresentar as informações dietéticas (não totalmente alheias à perspetiva gastronómica, como veremos) de autores que foram lidos e comentados por esse grande vulto da medicina romana que foi Galeno. À obra Das comidas de Mnesiteu de Atenas (IV a.C.) vai buscar a abonação do caráter indigesto (ou seja, o ser dúspeptos ou de difícil cozedura no estômago), flatulento e altamente nutritivo da castanha ${ }^{21}$. A ênfase na difícil digestão do fruto cru aparece igualmente confirmada por outra autoridade médica, Filótimo de Cós (III a.C.), no seu tratado Da alimentação $0^{22}$. Contemporâneo dele é Dífilo de Sifnos, que Ateneu evoca por atestar a dita propriedade de "altamente nutritivo" (gr. polutróphos), bem como por reforçar a natureza indigesta ${ }^{23}$. Este médico serve ao compilador romano para indicar uma outra peculiaridade da castanha, o "bom gosto" (gr. eúchulos). Informação que reforça a opinião de muitos estudiosos modernos de que os escritos médicos revelam sensibilidade para a vertente gastronómica da alimentação. Falta apenas destacar que as citações ou resumos das obras de Mnesiteu e de Dífilo contêm não só indicações precisas quanto às formas de cozinhar a castanha (insistindo nas tradicionais cozedura em água e assadura), como se esclarece que a vantagem de as comer cozidas está em que se tornam menos flatulentas e mais nutritivas do que as assadas ${ }^{24}$. Retenhamos, pois, que o método mais saudável de comê-las é cozidas.

No tratado agrícola do romano Plínio-o-Velho (I d.C.), repete-se a ideia de que a cozedura e a assadura são dos processos culinários a que mais se submete a castanha. $\mathrm{O}$ autor tanto refere que o método de as tornar mais agradáveis de comer é assá-las (lat. torrere has in cibis gratius) ${ }^{25}$, como indica que uma das espécies de castanhas mais vulgarizadas para consumo humano recebera o nome de "castanhas de cozer" (lat. castaneae coctiuae) ${ }^{26}$. Este texto tem ainda a particularidade de revelar não só que, tal como noutras fontes, se confirma o uso da farinha de castanha para confecionar pão, mas que este

20 Sobre esses médicos gregos cuja obra nos chegou muito fragmentada, vd. Nutton (2004: 125-129) e Brill's New Pauly (sub verba Diphilus, Mnesitheus, Phylotimus).
21 Cf. Ateneu, Deipnosofistas 53f.
22 Cf. Ateneu, Deipnosofistas 54b.
23 Cf. Ateneu, Deipnosofistas 54c-d.
24 Cf. Ateneu, Deipnosofistas 54d.
25 Cf. Da agricultura 15.92.
26 Cf. Da agricultura 15. 94. 
farináceo assume, agora em contexto religioso e não apenas de sobrevivência, a valência de substituto dos cereais. É o que se deduz da menção pliniana de que as castanhas "fazem uma espécie de pão para o jejum das mulheres" ${ }^{27}$.

Do universo idílico dos pastores das Bucólicas de Virgílio (I a.C.), percebemos, no seu primeiro poema, como o padrão identitário da alimentação romana são os cereais. Aí o pastor Melibeu evoca as saudades que, em terras bárbaras do ocidente e oriente conquistados, os Romanos, afastados da pátria pelas políticas expansionistas dos seus líderes, sentem das espigas (lat. aristae) e searas (lat. segetes) que marcam a paisagem agricultada da Itália (Buc. 1.6572). Também ele, exilado da grande Urbe nas montanhas, é convidado pelo seu interlocutor, o pastor Títiro, a contemplar a paisagem civilizada das villae e a saborear uma "mesa de delícias" pastoril. Compõem-na fruta e queijo, a saber: maçãs maduras, castanhas tenras (lat. castaneae molles), muito provavelmente por via da cozedura, e grande quantidade de queijos frescos (Buc.1.80-81).

Aliás, que a castanha é um fruto que no universo poético se assume como símbolo da simplicidade e/ou rusticidade da vida dos pastores confirma-o a intertextualidade evidente entre a Bucólica 2 de Virgílio e um trecho da Arte de amar (2.267-268) de outro célebre poeta romano, Ovídio (I a.C.-I d.C.). Do rol de prendas modestas (lat. rustica dona, v. 264), que o poeta aconselha se ofereçam à mulher amada ${ }^{28}$, fazem parte frutos da época, não só os colhidos no campo agricultado, o ager (numa alusão clara à plantação e cultivo agrícolas), de que não especifica as variedades, mas também um fruto da montanha, a castanha ${ }^{29}$.

Repare-se que, sob determinada perspetiva, o consumo deste fruto da montanha ganha um sentido de marcador social hierárquico. Conotado com uma mesa rústica, torna-se signo de humildade, pelo que não serve os propósitos ilustrativos de status da mesa dos aristocratas. Dessa aceção nos dá conta Marcial (I-II d.C.), romano natural da Hispânia, no poema 79, do seu livro X de Epigramas. Para retratar a rivalidade que opunha duas figuras (provavelmente ficcionais), Torquato e Otacílio, o poeta recorre a exemplos práticos dessa compita pública. O desnível social entre os dois rivais evidencia-se pelo confronto entre os "feitos" aristocráticos do primeiro e as humildes tentativas levadas a cabo pelo segundo para com ele ombrear. Ou seja, semear cem castanheiros (lat. castaneas centum, v. 6) é a resposta de Otacílio à plantação de loureiros (árvore símbolo de prestígio e distinção) de Torquato na sua propriedade agrícola (lat. suo in

27 Vd. lat. praestant ieiunio feminarum quandam imaginem panis (Da agricultura 15.92).

28 Embora não tenhamos uma explicação para o facto, a verdade é que em duas fontes latinas (aqui Ovídio e atrás Plínio, a propósito do pão de farinha de castanha) o fruto vem mencionado como ingrediente a marcar o universo feminino (amoroso ou religioso).

${ }_{29}$ É verdade que no poema não se faz uma menção explícita à montanha, mas ela depreende-se precisamente do facto de, para especificar os frutos de casca dura (lat. nuces, v. 267) a presentear, se dizer que esses frutos eram as castanhas, que o pastor Amarílis (num intertexto óbvio com o poema virgiliano) antes tanto apreciava e agora já não (At nunc castaneas non amat illa nuces, v. 267). 
agro, v. 5 ${ }^{30}$. Repare-se, pois, que fica implícita a prática do plantio sistemático de castanheiros, que não visaria apenas o aproveitamento alimentar do fruto, mas sim da sua madeira, conforme sublinham Conedera et al. (2004: 173-177).

Quanto às formas de consumo da castanha na cultura romana, já ficou evidente o seu aproveitamento em cru. Ainda inteiras, eram igualmente sujeitas aos dois métodos de cozedura principais: em água fervente (ou seja, cozidas) ou em ambiente seco, em contacto com o calor das brasas (ou seja, assadas). Consoante a tipologia da fonte escrita, assim deparamos com descrições mais genéricas ou técnicas. Na verdade, o facto de apenas possuirmos uma receita culinária em que o fruto aparece como ingrediente deve ser interpretado como o resultado expetável face quer à exiguidade de escritos técnicos de cozinha (no âmbito geral do universo literário clássico ${ }^{31}$ ) quer ao papel residual que desempenhou na alimentação padrão desses povos. Muito terá contribuído para a "marginalidade" desse alimento nas práticas alimentares das elites (aquelas que as fontes literárias mais extensamente documentam) a associação do fruto ao mundo dos humildes, bem como o ser considerado mais prejudicial do que benéfico para a saúde.

Ainda de Marcial chega-nos outro epigrama em que se menciona a castanha, dentro da lógica semântica de ser tomada por signo de simplicidade alimentar. Referimo-nos ao poema 78 do livro $\mathrm{V}$, no qual o poeta descreve uma mesa de fome (uso do vb. lat. esurire, v. 14). Desta fazem parte, entre outras comidas, as castanhas da região de Nápoles, assadas em lume brando ${ }^{32}$.

Embora as fontes, graças às parcas alusões que fazem à presença da castanha à mesa, possam insinuar uma presença discreta (por comparação a produtos mais referenciados) do fruto na alimentação, a verdade é que o mesmo, em pleno séc. $V$ d.C., numa região de reconhecida implantação da árvore (o atual território francês), consta da lista de alimentos a que o rei godo Teodorico I (511-534) teria acesso. Referimo-nos aos conselhos dietéticos que, sob a forma

30 O contraste de estatuto social entre um e outro rivais é denunciado por outros pares de "bens" concomitantes. Ao palácio (praetoria) de Torquato responde Otacílio com uma courela (breue rus), às termas revestidas de mármore (de marmore thermae) com uma gamela (cucuma) e ao cargo de cônsul com um humilde cargo de chefia local (magister).

31 Embora tenham proliferado do séc. $\mathrm{V}$ a.C. em diante, os livros de culinária gregos perderam-se na quase totalidade. Ficamos a dever ao bibliófilo e enciclopedista Ateneu de Náucrates o resgate de fragmentos desse património literário (na maioria dos casos apenas títulos de livros, alguns nomes dos autores e um receituário selecionado). Sobre essa literatura grega técnica, vd. Soares 2010. Dispomos, igualmente graças a esse compilador, de um mais extenso corpus do poema gastronómico de Arquéstrato (IV a.C.), também ele contendo receitas e já disponível em tradução portuguesa (Soares 2016). Da literatura latina recebemos o Livro de Cozinha tradicionalmente atribuído a Apício, estudado e vertido para português por Ornellas e Castro (2015). A receita 184 é a única em que a castanha figura como ingrediente e daí se depreende que também esse fruto poderia ser usado na preparação de molhos condimentados para acompanharem uma das mais vulgares leguminosas das cozinhas grega e romana, a lentilha.

32 Cf. v. 15: lento castaneae uapore tostae. 
de carta, lhe escreveu o médico grego Antimo, entretanto exilado na corte do rei ostrogodo Teodorico, o Grande. Nesse seu Tratado de dietética $a^{33}$, seguindo a boa tradição clássica de inserir informações sobre como cozinhar os alimentos que devem fazer parte de um regime alimentar saudável, o autor compõe, em latim, prescrições sobre 94 alimentos. Já bem para o final da carta (no cap. 88) surgem as indicações para o consumo da castanha, passo de que retiramos serem "cozidas" (lat. elixae) e "assadas" (lat.assae) as técnicas culinárias comuns. Nesse capítulo atesta-se, igualmente, a prática usual de as comer cruas.

Tratando-se de um fruto cujo tempo de vida se prolonga para lá do seu consumo em fresco (pelo que hoje justamente se agregam a outros frutos sob a denominação comum de "frutos secos"), as castanhas eram comidas e apreciadas muito tempo após a colheita. É esse processo longo de amadurecimento que permite que a pele se desprenda naturalmente do fruto, obtendo o que em português atual se designa por "castanha pilada". Devemos ainda evocar, a este propósito, o testemunho de um escrito latino, da autoria de um dos tratadistas agrícolas que mais influenciou a Idade Média, Paládio (IV-V d.C.). Autor do Opus agriculturae, composto em 14 livros, Paládio regista no mês de novembro (livro 12) uma informação particularmente pertinente em matéria de conservação do fruto cru ao longo de vários meses. O que esse passo da obra revela (12.7.22) é as origens multisseculares de uma prática que virá atestada como tradicional portuguesa na revista de culinária Banquete ${ }^{34}$. Informa o autor latino que se guardavam os frutos dentro de vasilhas e cobertas de $\operatorname{areia}^{35}$, sendo a forma de distinguir as sãs das estragadas a imersão em água. As que flutuassem não prestavam e as que ficavam no fundo mantinham a sua qualidade ${ }^{36}$.

33 Cujo título original é De observatione ciborum, de que recomendamos a edição latina e tradução para inglês de Grant (1996).

${ }_{34}$ Vd. n. ${ }^{\circ} 130$, dezembro de 1970, p. 10.

35 Cf. lat. in uasculis seruant harena pariter missa (12.7.19). Note-se que, como esclarece mais abaixo (12.7.22), a imersão em areia tem por objetivo evitar que os frutos se toquem, o que aceleraria a sua deterioração. Nesse passo indica outras formas/recipientes de conservação: enterradas num local bem seco, dentro de potes cerâmicos novos, ou guardadas em recipientes feitos de varas de faia, tapadas, de forma a não deixar nenhuma abertura, ou escondidas em palha miúda de cevada, ou guardadas em cestos de vime dos pântanos, de malha bem apertada (uel in uasculisfictilibus nouis conditae et loco sicciore defossae, uel inclusae uirgeis ex fago receptaculis et lutatae ut spiracula non reliquas, uel hordei paleis minutissimis obrutae, uel palustre ulua figuratis densioribus sportis reclusae, 12.7.22). Todas estas recomendações visam evitar o contacto com a luz e o ar, agentes aceleradores da putrefação. Não existe tradução em português para a obra de Paládio, donde se recomenda a tradução em inglês de Fitch (2013) e o texto original latino fixado por Rodgers (1975).

${ }_{36}$ Cf. lat. post dies triginta eas remota harena in aquam frigidam mittis. Quae sanae sunt merguntur; supernatant quaecumque uexata est (12.7.18). Este é um método caseiro a que ainda se recorre em algumas casas portuguesas. Estamos, uma vez mais, perante um bom exemplo de como a cultura popular segue um continuum diacrónico que mantém as boas práticas e ensinamentos transmitidos de geração em geração. 
Outra forma de prolongar a validade do alimento e de, simultaneamente, aumentar o seu potencial culinário é produzir o que modernamente se chama de transformados. Referimo-nos à moagem do fruto, que passa a ser usado nos preparados que tradicionalmente a culinária reservava às farinhas de cereal. Assim, na sua qualidade de substituta das farinhas convencionais, a farinha de castanha entra na confeção de papas, pão e bolos. As razões para essa substituição poderiam ser de ordem económica e ecológica, mas também religiosa. A abundância de frutos, acompanhada da carência e carestia de cereais, não é um aspeto mencionado nas fontes clássicas, mas bastante admissível, quando comparado com comportamentos registados em idênticos contextos para períodos da história posteriores (que veremos de seguida). Há, no entanto, uma referência na Anábase do grego Xenofonte (IV a.C.), que deve ser interpretada como evidência do aproveitamento da castanha para farinha em zonas onde a produtividade do fruto estimulava esse uso culinário. Ao falar dos Mossinecos, habitantes do sudeste montanhoso da costa do Mar Negro (região a norte da atual Arménia), o que Xenofonte destaca da sua alimentação é precisamente eles comerem castanhas cozidas ou em pão $0^{37}$. Confirma-se, assim, a relação direta entre geografia/ecologia da região de montanha e o consumo da castanha.

Uma vez que o enfoque geográfico do presente estudo é o atual território português, importa sintetizar as principais conclusões a que chegaram botânicos e arqueólogos quanto à implantação geográfica e distribuição do cultivo do castanheiro ao longo da nossa história. Para as épocas mais recuadas de ocupação humana, as mais recentes investigações arqueobotânicas, em sítios escavados na região norte de Portugal, confirmam não só que a castanha é uma espécie nativa, mas também que se terá assistido ao seu cultivo a partir da ocupação romana. Nesse sentido apontam os achados de exemplares de castanea sativa em contexto aquático, encontrados em escavações nas termas de Chaves (Aquae Flaviae). Como alertam os autores do estudo sobre os restos botânicos encontrados (Vaz et al. 2016b), o tamanho das cascas de castanha sugere que seriam de plantas cultivadas. Outro indicador importante da prática da silvicultura do castanheiro, indiciada em contexto arqueológico do noroeste peninsular romano, é a presença de carvões de castanho apenas em sítios dessa região (Monte Mozinho, Penafiel ${ }^{38}$; Castro de Cidadelhe, Mesão Frio ${ }^{39}$ ).

É preciso esperar pelo séc. XX para assistirmos ao registo de censos do plantio de castanheiro e a estudos quantitativos de produção anual de castanha. No entanto, antes de iniciarmos a nossa investigação sobre o consumo da castanha em Portugal, da Idade Média em diante, há que apresentar, ainda

\footnotetext{
37 O termo grego interpretado como castanha é a palavra káryon, que acima já vimos ter essa valência.

38 Vd. Vaz-Tereso 2012.

39 Vd. Vaz et al. 2016a.
} 
que brevemente, os dados que possuímos sobre a distribuição do castanheiro no nosso país. Para proceder a essa síntese, recorremos ao "estado da arte" elaborado por Jorge Ferreira Cardoso e Mário Pimentel Pereira (2007).

O primeiro dado a reter é que atualmente as regiões de maior densidade de souto são as terras frias de Trás-os-Montes e as Beiras. Seguem-se núcleos menores, a sul, no Nordeste Alentejano (Serra de S. Mamede e Marvão) e no Norte Algarvio (Serra de Monchique), e, a norte, no Minho Interior (Serra do Gerês). Há ainda uma plantação dispersa por vários pontos a norte do Tejo, bem como manchas isoladas na Madeira (Curral das Freiras e Serra da Água) e Açores. Possuímos dois grandes censos do plantio da árvore, um feito na década de 50 e outro na de 80, ambos úteis ao nosso estudo, uma vez que a revista Banquete (1960-1976) e o livro de Cozinha Tradicional Portuguesa (1982) de Maria de Lourdes Modesto, ambos fontes para o nosso estudo do receituário da castanha, foram editados em datas próximas desses períodos. A comparação entre os valores de área de plantio de uma e outra datas revelam um decréscimo a rondar os 43\% (de 70.000 ha para 30.000 ha), sendo que, nesse período, metade do total da zona de souto se concentrou numa única região, Trás-osMontes, aquela que, como veremos pela análise das compilações culinárias sob análise, sobressai do panorama regional da gastronomia da castanha. Cardoso e Pereira (2007: 25-26) avançam com quatro causas principais (biológicas, económicas e sociais) para esse decréscimo: a doença da "tinta do castanheiro"; a introdução da cultura da batata e a difusão de outras culturas mais rentáveis e fáceis de produzir (milho, oliveira, vinha e fruticultura), responsáveis pelo desinteresse por uma cultura mais exigente ao nível das técnicas de cultivo e de retorno financeiro mais demorado; o despovoamento das zonas rurais do plantio de castanheiro e consequente abandono da castanha na alimentação do quotidiano; crescente abate das árvores, sem reposição da área plantada.

Contudo, dos anos 80 em diante, sobretudo após a entrada, a 1 de janeiro de 1986, de Portugal na então CEE (Comunidade Económica Europeia), designada de EU (União Europeia) a partir de 1992, a economia do país teve uma evolução positiva, tendo-se assistido a políticas de incentivo ao plantio do castanheiro. Este apoio estatal fez recrudescer o interesse dos agricultores pelo plantio da árvore e teve, a médio-longo prazo, o efeito de valorização do produto no mercado, através do reconhecimento de quatro zonas DOP (Denominação de Origem Protegida) da cultura da castanha. Repare-se a dianteira assumida pela zona que tradicionalmente sempre manteve uma área expressiva de plantio, Trás-os-Montes, que tem duas regiões DOP: Castanha da Terra Fria e Castanha de Padrela. As outras duas zonas situam-se nas regiões das Beiras (Castanha dos Soutos da Lapa) e Nordeste Alentejano (Castanha do Marvão). 
Teremos essa informação em conta quando passarmos a considerar a Época Contemporânea ${ }^{40}$, na medida em que, sempre que disponível, o cruzamento de dados relativos à produção com fontes sobre consumo é precioso para um mais cabal entendimento do papel de determinado produto na alimentação. De momento passaremos a considerar os resultados que a pesquisa efetuada em documentação portuguesa do séc. XIII permitiu alcançar.

\section{2. Cultura e consumo de castanha no Portugal medieval}

Em termos de uso do fruto como sustento, o seu consumo dava-se tanto inteiro como moído, sendo usado na preparação e/ou como substituto de outras farinhas mais nobres, feitas de cereal (em particular o trigo). Porque entra na alimentação com a função de alimento básico (ocupando o lugar de papas ou pão de cereais), a castanha desempenha um lugar primordial enquanto sustento de populações que dispõem desse fruto em abundância. Assim, como bem observam Giovanni Cherubini (1981: 249) e Massimo Montanari (2012: 124-125), a castanha é, para as populações de montanha, geografia do plantio da árvore, o "pão da árvore" e o castanheiro a "árvore do pão". Logo, os que não podem obter o cereal, por não terem meios económicos e sobretudo quando ele não abunda no meio natural em que vivem, comerão um qualquer substituto. Os estudos modernamente feitos à composição química e ao valor nutritivo da castanha comprovam haver muitas semelhanças entre a castanha e cereais como o trigo e o arroz (para além da batata), o que demonstra que uma escolha alimentar ditada por razões geográfico-culturais (lato sensu) se revelou válida do ponto de vista científico (stricto sensu) ${ }^{41}$. Com a farinha de castanha confecionavam pão, ainda que de má qualidade, como alertarão sobretudo as fontes primárias médicas, mas também a consumiam em papas ou bolos, suplantando largamente o recurso ao cereal (Cherubini 1981: 253, 255). E não se alimentavam com castanhas apenas por ocasião da sua colheita, mas durante todo o ano, pois secavam-nas para aumentar a sua durabilidade. É interessante retirar desse uso da castanha como substituto do cereal a conclusão segundo a qual, muito antes de se conhecer as propriedades nutricionais do fruto, a experiência de muitas gerações "ensinara" ao consumidor que os dois alimentos tinham usos culinários e dietéticos equivalentes.

Está confirmado que o recurso dos povos das altas colinas e montanhas à castanha era uma constante europeia. Alfio Cortonesi não hesita em afirmar que "dos Pré-Alpes ao maciço do Amiata, a nordeste de Siena, das montanhas da Ligúria até ao Apeninos calabreses, os camponeses compensavam a falta de trigo com aquilo a que se chama, de forma sugestiva, a farinha de pau". Mas não deixa de referir que o mesmo acontecia em França, pois o souto

\footnotetext{
$40 \quad$ Vd. infra ponto 2.2 .

${ }^{41}$ Vd. as conclusões a que chegaram Cardoso-Pereira (2007).
} 
modelava a paisagem do Périgord ${ }^{42}$, do Limousin, do Auvergne, das montanhas do Lyonnais e de Cervennes (Cortonesi 2001: 35). Em tempos de expansão demográfica, em terras onde não havia solos aráveis, os homens recorriam ao plantio de castanheiros, derrubando as espécies das florestas primitivas, pelo que o castanheiro se transformou em qualquer coisa intermhamelahaem para ovinhodoa floresta e que o catanheiro e arvores $\mathrm{d}$ efruto bem como se explorava a riqueza das florestas, pesandotédia entre uma planta da floresta e uma planta agrária (Cherubini 1981: 249). Em Portugal, na época medieval, o castanheiro encontra-se, predominantemente, nas terras altas do Norte e, se bem que seja uma árvore espontânea em alguns espaços, também não restam dúvidas de que a cultura do castanheiro acompanhou o percurso do povoamento ${ }^{43}$.

A investigação levada a cabo para o território português durante a Idade Média assentou nas Inquirições ordenadas por D. Afonso II em $1220^{44}$, na secção Foros e Dádivas. Uma primeira observação se impõe quanto aos resultados, a saber: ainda que bastante completo quanto à expansão do castanheiro e às valências da castanha no século XIII, o quadro obtido não deixa de ser espacialmente circunscrito. Atentemos em algumas das limitações dos dados obtidos. Em primeiro, estas inquirições abrangeram apenas parte do território de Entre Douro e Minho, e muito pouco do de Trás-os-Montes e do norte da Beira. Para além disso, na rubrica de Foros e Dádivas, no geral apenas se colhem elementos, se houver rendas e direitos a pagar ao monarca, ficando de fora todas as terras sob a alçada de outros senhores. Ainda assim, sempre dentro deste quadro parcial, podemos tecer os contornos da distribuição territorial de soutos, castanheiros ou castanha em concelhos atuais de quatro distritos, a saber: em dez concelhos de Braga, em quatro de Vila Real, em dois do Porto e em outros tantos de Viana.

42 Concretamente sobre a castanha nesta região, vejam-se os estudos, em longa diacronia, sobre a temática na obra coletiva La châtaigne en Périgord (Leroyer 2007).

${ }^{43}$ Assim acontece também na Itália, em que o castanheiro passa a cultivar-se, a "domesticar-se", e surgem mesmo contratos que especificam como se devia plantar e defender os frutos dos animais (Montanari 2012: 127-128). Esta mesma "domesticação" do bosque (com obrigações contratuais de plantação de castanheiros de fruto, que fizeram recuar o castanheiro selvagem, na região dos Apeninos, entre o Piemonte e a Ligúria) é estudada por Rao (2013: 207-227).

44 Para mais informações sobre estes inquéritos mandados fazer por D. Afonso II para conhecer os bens e direitos da coroa, leia-se Marques 1971: 442-443; Barros 1945: 442-443; 1949: 277-286; 1949: 343-352. É certo que nas inquirições de 1258, ordenadas por D. Afonso III, também há informações sobre esta árvore e fruto (Barros 1950: 107), mas, por uma questão de tempo e espaço, circunscrevemo-nos apenas às anteriores. 
Um doce e nutritivo fruto: a castanha na história da alimentação e da gastronomia portuguesas

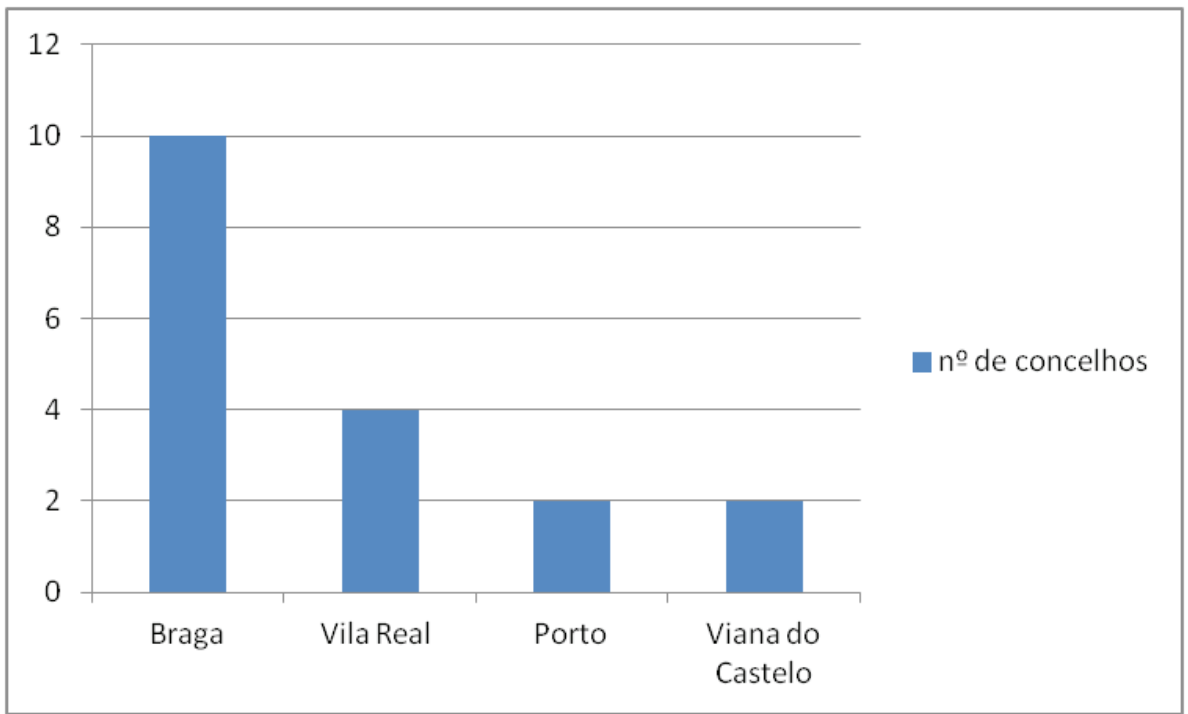

Quadro 1: Inquirições de 1220 (Foros e Dádivas) - Número de concelhos, nos distritos assinalados, com referências a soutos, castanheiros ou castanhas

Nos dois concelhos do distrito do Porto colhemos indicações para duas freguesias (uma em Santo Tirso e outra em Amarante).

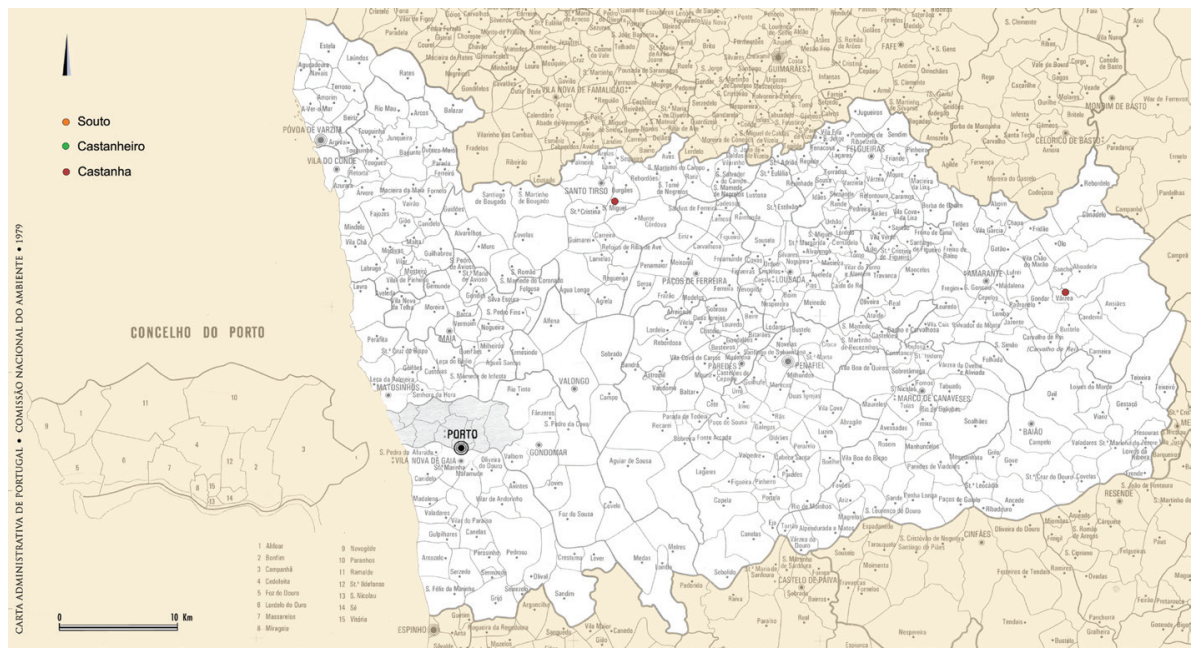

Mapa 1: Inquirições de 1220 (Foros e Dádivas) - Concelhos, no distrito do Porto, com referências a soutos, castanheiros ou castanhas ${ }^{45}$

${ }^{45}$ O desenho dos mapas é da autoria de José Luís Madeira, a quem muito agradecemos. 
Nos quatro concelhos do distrito de Vila Real surgem alusões em oito freguesias (quatro no concelho de Vila Real, duas no de Sabrosa, uma no de Santa Maria de Penaguião e uma no de Ribeira de Pena).

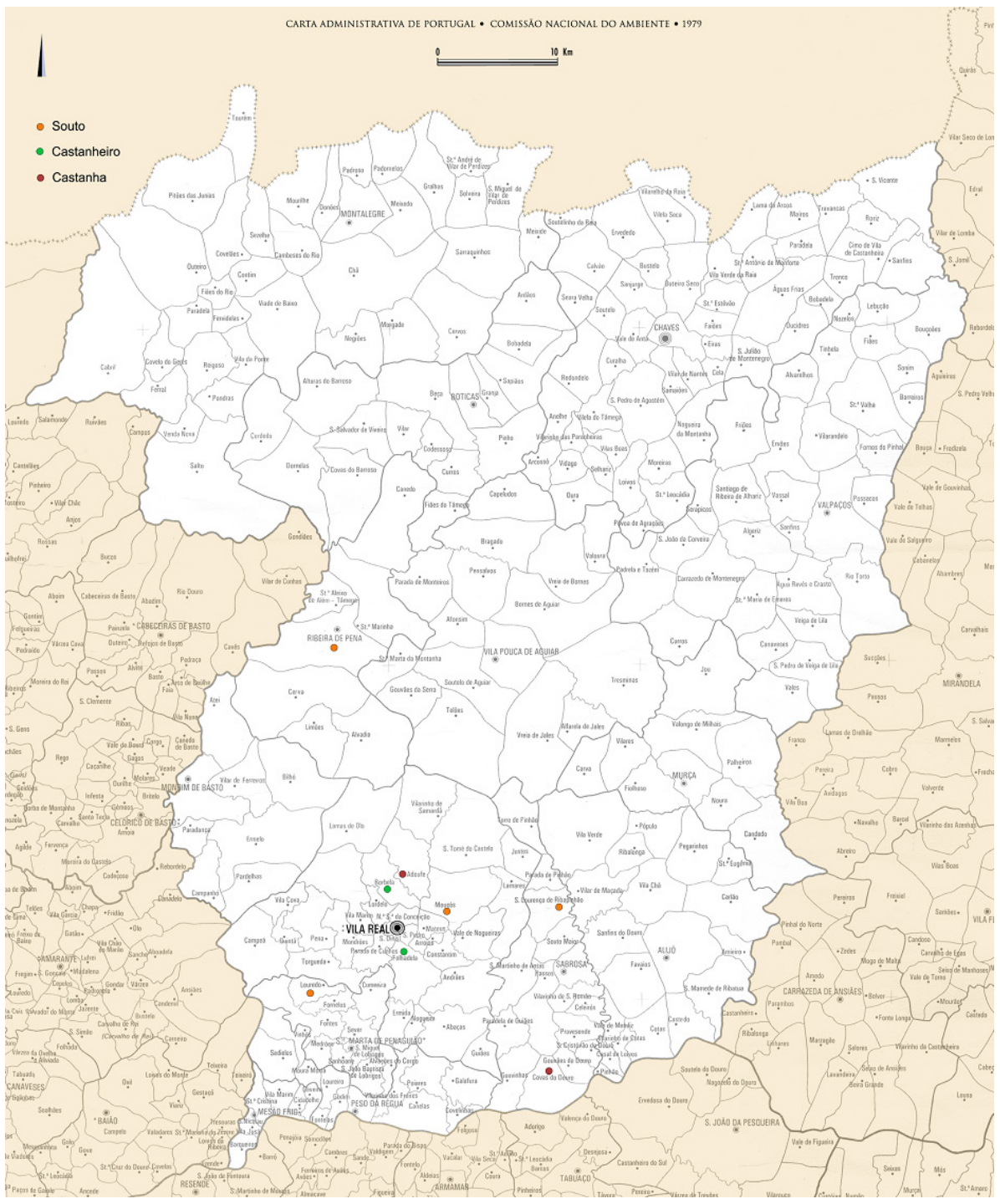

Mapa 2: Inquirições de 1220 (Foros e Dádivas) - Concelhos, no distrito de Vila Real, com referências a soutos, castanheiros ou castanhas

No distrito de Viana é nos concelhos de Ponte de Lima e de Ponte da Barca que surgem informações em cinco freguesias de cada uma delas. 
Um doce e nutritivo fruto: a castanha na história da alimentação e da gastronomia portuguesas

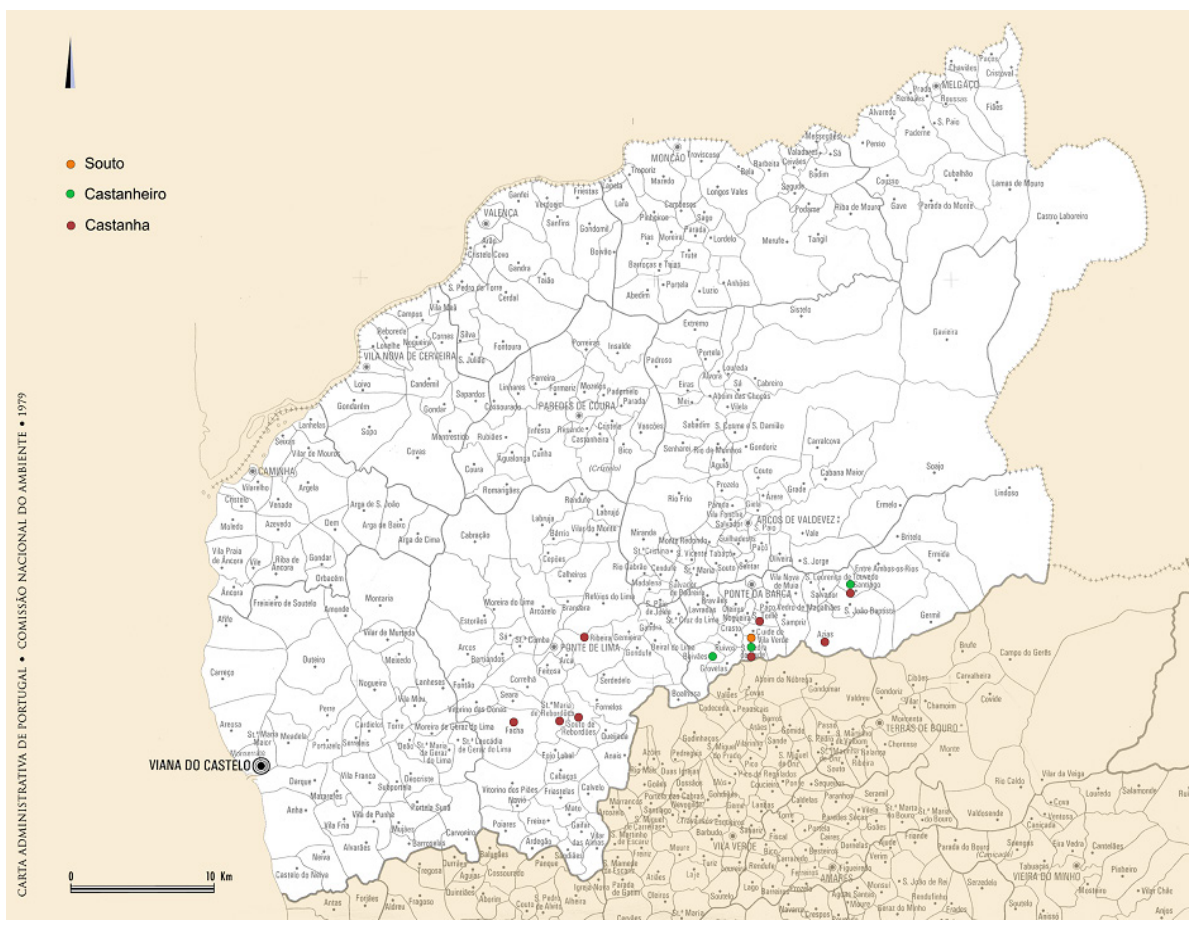

Mapa 3: Inquirições de 1220 (Foros e Dádivas) - Concelhos, no distrito de Viana do Castelo, com referências a soutos, castanheiros ou castanhas

Finalmente, nos dez concelhos do distrito de Braga, há alusões em 48 freguesias (onze no concelho de Guimarães, sete no de Vila Verde, oito no de Terras de Bouro, sete em Póvoa do Lanhoso, cinco em Braga, três em Barcelos e em Vieira do Minho, duas em Amares, uma em Esposende e em Fafe). 


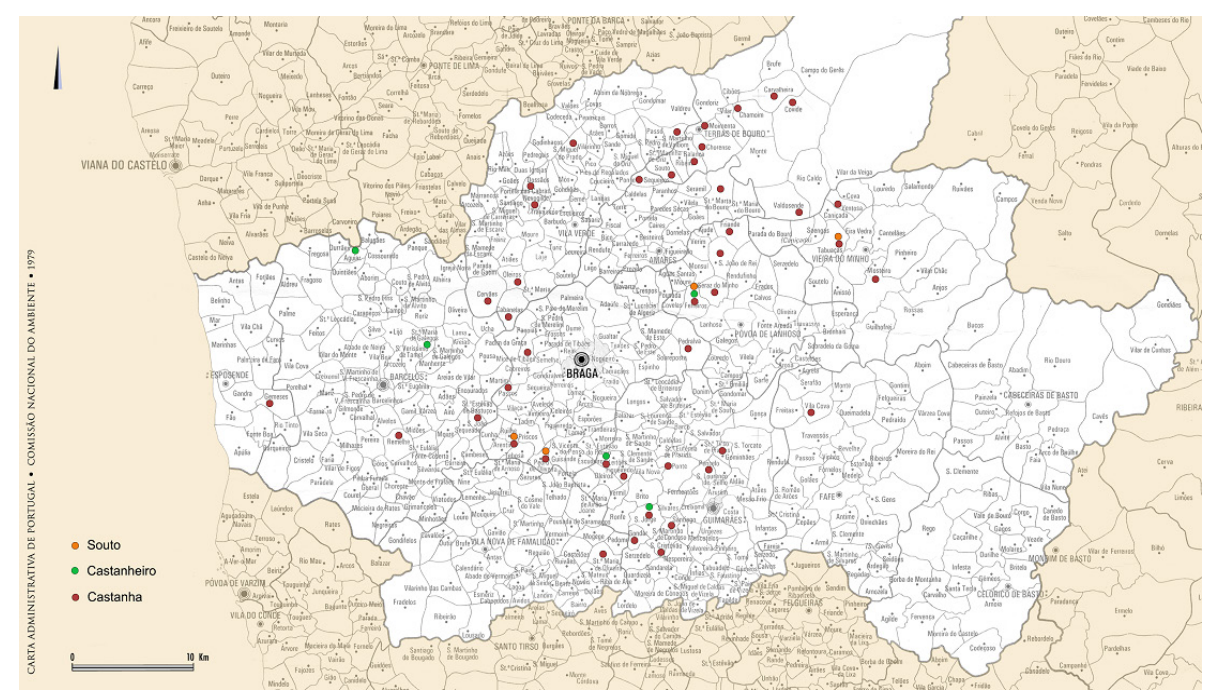

Mapa 4: Inquirições de 1220 (Foros e Dádivas) - Concelhos, no distrito de Braga, com referências a soutos, castanheiros ou castanhas

A esmagadora maioria dos dados diz respeito, como era de esperar, a castanhas pagas por rendas ou foros. Pontualmente encontramos soutos, que nesta área admitimos serem de castanheiros, para além da especificação apenas de castanheiros, por certo árvores isoladas ${ }^{46}$, muitas vezes a par de outras árvores de fruto, sobretudo cerejeiras e macieiras ${ }^{47}$, tanto na posse do rei como na de particulares. Mas curiosamente os foros que impendem sobre os soutos e castanheiros, na maior parte das vezes, não são pagos em castanhas ${ }^{48}$, embora haja exceções ${ }^{49}$. Logo, poderemos admitir que aqui também se encontrariam castanheiros bravios, que valiam pela madeira e lenha que podiam fornecer para múltiplos fins ${ }^{50}$. Mas, mais comummente, apercebemo-nos da presença

46 Em alguns casos poderiam estar mesmo a demarcar as propriedades (CHDJI, vol. II, t. 1, doc. 155, p. 97, de Lisboa, 2 de maio de 1389).

$47 \mathrm{PMH}$, Inquisitiones, I: 130.

48 Alguns foros de soutos pagavam-se em moeda, pão, galinhas, frangões, ovos, coelhos, manteiga, bragal e ferro (PMM, Inquisitiones, I: 83, 86, 121, 123, 124, 126). Muitos dos foros dos castanheiros traduziam-se em numerário, capões, galinhas, frangões e ovos (PMM, Inquisitiones, I: $78,81,83,96,119,120,124,128)$.

${ }_{49}$ Assim encontramos também foros em castanhas ou castanhas secas de certos soutos ou castanheiros (PMM, Inquisitiones, I: 79, 118, 145, 146, 147).

50 Embora o nosso estudo incida sobre o aproveitamento alimentar do fruto do castanheiro, convém ter presente que várias fontes atestam o uso polivalente da planta. A título de exemplo, refira-se o que sobre ele escreve o jurista bolonhês Pietro del Crescenzi, na sua obra Liber ruralium commodorum, publicada em Augsburg em 1471, naquele que veio a tornar-se o primeiro tratado impresso de agricultura (escrito entre 1304 e 1309, dedicada a Carlos II de Nápoles, e mandado traduzir para francês pelo rei Carlos V de França, em 1373). Aí arrola as múltiplas utilizações 
de castanheiros mansos, por certo com predominância da espécie europeia castanea sativa, sendo muitos dos pagamentos dos foros e rendas de certas herdades e casais das freguesias traduzidos em castanhas.

$\mathrm{O}$ facto de tais entregas do fruto serem feitas ao rei, ou ao senhor e tenente da terra (que era um membro da nobreza da maior importância, um rico-homem delegado do poder régio), revela de forma inequívoca que também os monarcas e privilegiados estavam interessados na arrecadação da castanha, que não deixariam de degustar, quando, na itinerância da corte, passavam por essas terras. Por sua vez os oficiais régios, por todos o mordomo, que era o cobrador das rendas reais, empenhavam-se em arrecadar tal produto que também contribuía para o seu sustento. Com castanhas se satisfaziam a fossadeira ${ }^{51}$ e o terrádigo ${ }^{52}$ a versar ao rei, mas também alguns foros que revertiam para o monarca ou para igreja, como a encensoria ${ }^{53}$.

A documentação consultada fornece ainda outros dados interessantes, como os quantitativos de grandeza. Torna-se claro que as medidas que incidiam sobre este fruto eram as mais variadas ${ }^{54}\left(\right.$ alqueire $^{55}$, teiga ${ }^{56}$, sesteiro $^{57}$, quarteiro $\left.{ }^{58}\right)$, que seriam submúltiplos do moio $^{59}$, no geral o moio de Braga

do castanheiro, a saber: o seu fruto, a castanha, durava muito tempo e a farinha com ela feita era muito nutritiva; a madeira do castanheiro empregava-se na construção, na confeção de objetos, em vasilhame, em tábuas para as embarcações e, na agricultura, com os seus ramos faziam-se boas estacadas para as vinhas e suportes para as ramadas; além disso, utilizava-se para o curtimento das peles e a sua casca, folhas e ouriço serviam para o tingimento de panos (Mane 2006: 263; Cherubini 1981: 249-252). No Portugal medieval será de destacar a sua importância na construção e aparelhagem dos navios, que sustentavam a armada do reino e a frota transportadora e comercial dos mercadores. De facto, na quitação dirigida a Gonçalo Pacheco, tesoureiro das coisas de Ceuta em Lisboa, referente aos anos de 1453 e 1454, anotam-se diversos pagamentos de varas de castanheiro para caravelas e navios que foram levar carregamentos de alimentos e bens a Ceuta (DP, Suplemento, doc. 228, pp. 351, 352, 355, de 2 de março de 1456).

51 PMH, Inquisitiones, I: 94, 95, 95, 96, 144. A fossadeira era inicialmente uma multa paga pelos que não iam ao fossado - guerra ofensiva - ou uma remissão desse dever e que, terminada a guerra contra os muçulmanos, se torna num tributo fixo e anual (Gonçalves 1965: 285-286).

52 PMH, Inquisitiones, I: 118. O terrádigo era a renda que se pagava por cultivar terra alheia (Viterbo 1966, II: 607, sub verbum Terradigo).

53 PMH, Inquisitiones, I: 76.78 (para um mosteiro), 98, 117, 130 148. A encensoria ou censória (também designada colheita, jantar, vida ou serviço) era um tributo pago para sustentar o rei e a sua comitiva, quando passavam pelas terras, e que depois se tornou fixo e anual, mas também podia ser um direito a reverter para mosteiros e igrejas (Viterbo 1966, II: 89, sub verbum Censo).

54 Sobre todas estas medidas, leia-se Marques 1971: 371-374.

55 PMH, Inquisitiones, I: 78, 80, 82, 88, 94, 95, 111, 118,120, 131, 145, 146.

$56 \mathrm{PMH}$, Inquisitiones, I: 79, 80, 91, 95, 96, 118, 120, 121, 130, 144, 145, 146.

$57 \mathrm{PMH}$, Inquisitiones, I: 80, 130, 143.

58 PMH, Inquisitiones, I: 82, 89, 100, 117, 130, 143, 146, 147.

$59 \mathrm{PMH}$, Inquisitiones, I: 148. 
que corria na região $0^{60}$, mas também almude ${ }^{61}$, canada $^{62}$, cesta $^{63}$ ou mesmo um punhado ${ }^{64}$.

Como vimos já para a Antiguidade, também aqui se confirma que a castanha tanto era consumida fresca como seca, podendo então figurar em qualquer estação do ano à mesa dos homens. Aliás, a importância da castanha na alimentação humana advinha justamente dessa sua capacidade de conservação, que prolongava o recurso a este alimento muito para além da sua colheita $^{65}$. As duas técnicas de conservação então praticadas consistiam em manter as castanhas frescas no ouriço, apanhadas ainda verdes e guardadas em sítio fresco ou em saibro, ou secá-las ao sol ou ao calor do fogo (Cherubini 1981: 265-268; Montanari 2012: 129-130). Vejamos como destas diferentes condições de maturação e conservação nos dão testemunho as inquirições. Os foreiros tanto entregavam aos senhores ou oficiais régios castanhas verdes ${ }^{66}$, portanto certamente colhidas antes do tempo e ainda com os seus ouriços, como secas ${ }^{67}$ ou pisadas ${ }^{68}$. Neste último caso estamos já perante as castanhas piladas, secas e limpas da sua casca, que tinham exigido o prévio trabalho de as "riscar", ou seja, segundo Viterbo, de pisar com os pés para lhes tirar a casca $^{69}$. Também parece importante assinalar que, por vezes, as castanhas se associavam nos foros a outros frutos de consumo em seco, tal como as nozes $^{70}$ ou as leguminosas, como favas ${ }^{71}$ e feijões ${ }^{72}$ (cuja validade de consumo se prolongava também pela sua secagem).

A nossa fonte é igualmente reveladora de aspetos relativos à colheita propriamente dita (calendário e mão de obra). Percebe-se que as castanhas verdes cobravam-se na época da sua colheita, a qual poderia começar em Setembro, pois se exigiam pagamentos pela festa de S. Miguel ${ }^{73}$, ainda que talvez a sua

60 Tinha uma capacidade de 24 alqueires.

${ }_{61} \mathrm{PMH}$, Inquisitiones, I: 80, 82, 93, 95, 130. Ainda que não sendo uma regra absoluta, o almude parece estar relacionado sobretudo com as castanhas secas.

$62 \mathrm{PMH}$, Inquisitiones, I: 79.

63 PMH, Inquisitiones, I: 89, 90, 91, 95, 96, 147, 148, 152.

$64 \mathrm{PMH}$, Inquisitiones, I: 149.

65 Assim em França é estimado um consumo de $2 \mathrm{Kg}$ de castanha pro capite durante seis ou sete meses (Montanari 2012: 130).

$66 \mathrm{PMH}$, Inquisitiones, I: 80, 99, 111, 120 (castanhas verdes e secas), 130 (castanhas verdes e secas e cestos de maçãs), 147 (castanhas verdes e secas e cestos de cerejas).

${ }_{67} \mathrm{PMH}$, Inquisitiones, I: 79. 89, 94, 95, 98, 100, 117, 118, 130, 145, 146, 147, 148.

$68 \mathrm{PMH}$, Inquisitiones, I: 137, 144.

69 Vd. Viterbo 1966, II: 78-79 (sub verbum Castanhas Pizadas).

70 PMM, Inquisitiones, I: 143 (três sesteiros de castanhas e uma teiga de nozes).

71 PMH, Inquisitiones, I: 148 (em S. João de Rei os que não davam castanhas entregavam fabis in baginis, as quais se poderiam depois secar).

$72 \mathrm{PMH}$, Inquisitiones, I: 120, 137.

73 PMH, Inquisitiones, I: 88 (em S. Julião de Sequeira, concelho de Braga, exigia-se dos seus 35 herdadores, entre outros géneros, singulos alqueires de castaneis viridibus pro festo Sancti Micahaelis...). 
apanha se fixasse sobretudo no mês seguinte, o qual nos calendários agrícolas encontramos geralmente evocado por homens a varejar os castanheiros e mulheres a recolherem os frutos em cestos $^{74}$ (Mane 2006: 263). Nessa árdua tarefa da recolha far-se-ia apelo aos braços que estivessem disponíveis ${ }^{75}$, como acontecia no Souto de Silvã (freguesia de S. Paio de Ruilhe, concelho de Braga), obrigando-se os moradores a dar a cada um desses trabalhadores, para se dessedentarem, uma cabaça de vinho, e a alguns outros nomeados, ainda capões, galinhas, frangões e ovos ${ }^{76}$.

Detetamos, igualmente, em outras fontes compulsadas, a confirmação da conotação social humilde associada ao seu consumo. A importância da castanha para os mais pobres está claramente demonstrada num documento em que D. Dinis doara um souto à Sé de Lamego, mas revogou tal ato a 12 de fevereiro de 1304, com a alegação de que tal prédio era "o souto dos pobres de Lamego" 77 . Este favorecimento dos pobres da região, com castanhas para matar a fome, continuou a manter-se ao longo do tempo, pois, quando D. João I doou a um escudeiro os direitos que ele possuía no souto de Madões do almoxarifado de Lamego, lê-se que excetuou "as castanhas que tem dadas aos proues" 78 .

Uma similar situação ocorria no concelho de S. Martinho de Mouros, hoje uma freguesia na margem esquerda do rio Douro, que integra o concelho de Resende. Assim, quando o corregedor Afonso Anes se deslocou a esse concelho, no ano de 1342, para, juntamente com as autoridades locais, sancionar os usos e costumes locais, nesse regulamento ficaram determinadas sanções para a destruição de castanheiros tanto "nos soutos delRey que som de esmola"79 como nos outros, demonstrando uma vez mais que os monarcas reservavam alguns dos seus castanhais para suprir a fome dos mais carenciados.

Mas, mais amplamente, os soutos eram uma reserva de alimento para a população em geral e por isso o concelho de Lamego, nas cortes de Lamego de 1352, ergueu a voz para denunciar que um senhor (Gil Vasques de Resende) e a sua comitiva tomavam bens aos lavradores e cortavam os soutos, causando-lhes grande dano, o que D. Afonso IV não permitiráa ${ }^{80}$. Mais tarde D. Manuel,

74 Cherubini (1981: 276-277) diz que o tempo da recolha variava com a latitude, a altitude e as qualidades do fruto, podendo situar-se entre os primeiros dias de setembro e os últimos de dezembro.

75 Também em Itália os proprietários de castanheiros recorriam ao trabalho de pessoas da família - mulheres e rapazes - ou a assalariados (Cherubini 1981: 277).

76 PMH, Inquisitiones, I: 89.

77 Manda então ao seu delegado Estêvão Martins de Alvelos que: "filhedes esse souto e que o guardedes que hy nenguum faça mal nem força nem no corte nenguum nem colha nenguum ende castanhas senom no tempo que deve de guisa que ajam ende os pobres aquello que soyam a aver compridamente assi como o nunca melhor ouveram e eu esto me terey de vos por servido e gracir vo lo ey muyto" (ANTT - Chancelaria de D. Dinis, liv. III, fl. 29v).

78 CHDJI, vol. II, t. 1, doc. 461, de Lisboa, 24 de novembro de 1390.

79 Collecção, IV: 590.

80 CPRDAIV: 143. 
confirmando privilégios ao concelho de Sintra, que davam liberdade aos seus moradores para cortar lenha nas matas coutadas, interditava-lhes, porém, o abate de castanheiros e sobreiros, assim protegendo estas espécies ${ }^{81}$.

A valoração do castanheiro fica ainda bem patente quando deparamos com doações régias destas árvores a recebedores de alguma importância, para além dos monarcas também cuidarem da sua exploração ${ }^{82}$. Assim D. João I, em 1384, fez doação perpétua e hereditária de um souto, no termo da Covilhã, a Fernão Velho, cavaleiro da ordem de Santiago e comendador de Aldeia Seca ${ }^{83}$; em 1389, doou perpétua e hereditariamente o souto de Madões, em Lamego, ao seu vassalo Gonçalo Vasques Coutinho ${ }^{84}$; e, em 1404, doou, enquanto fosse sua mercê, ao alcaide do castelo da Covilhã, um souto com moinhos no almoxarifado da Guarda ${ }^{85}$. Importa sempre não esquecer que em questão está a valência da árvore no seu todo. Em suma, os agraciados com tais soutos ficavam seguramente com boa madeira para diferentes usos, com castanhas para degustarem com a sua clientela, com alimentos para os seus oficiais e servidores ou mesmo com um fruto a lançar no mercado.

De facto, se a castanha respondia essencialmente à necessidade dos que as produziam, elas tinha também algum consumo fora dos seus lugares de origem. Em Itália, as melhores espécies chegavam aos mercados das cidades, sabendo-se que marcavam presença em Milão nos finais do século XIII e em meados do século seguinte em Nápoles, Messina, Veneza e Génova (Cherubini 1981: 263-264; Cortonesi 2001: 35). Mas as variedades de qualidade superior eram mesmo exportadas. As melhores da Lombardia destinavam-se a Paris e as da Campânia ao Egito e Constantinopla, nos séculos XIII e XIV. Os mercadores das cidades italianas contratavam até com os produtores os destinos das diversas espécies de castanhas, com vista ao comércio local ou à exportação (Cherubini 1981: 264; Montanari 2012: 131-32).

${ }^{81}$ HFAC, IV, doc. 66, pp. 74-75, de 3 (?) de fevereiro de 1497.

82 Uma casa e um souto na Guarda foram aforadas por D João I ao porteiro do almoxarifado por 20 libras anuais (CHDJI, vol. II, t. 1, doc. 596, p. 306, de Viseu, 7 de março de 1392). Um casal em S. Martinho de Mouros estava emprazado já em tempos de D. Dinis, e continuou com D. João I, pela renda de $1 / 4$ do pão, vinho e castanhas secas além de $1 / 6$ de linho, bem como, se plantassem vinha, dariam $1 / 4$ do vinho (CHDJI, vol. II, t. 3, doc. 1542, pp. 280-282, de Lisboa, 25 de outubro de 1403). Ainda em 1405 D. João I está a emprazar em três vidas um souto no termo da Covilhã (que aliás limita com outros soutos) pela renda de 25 soldos da moeda antiga (CHDJI, vol. III, t. 1, doc. 303, p. 187, de Lisboa, 20 de julho de 1405).

83 CHDJI, vol. I, t. 1, doc. 217, p. 109-110, de Lisboa, 20 de agosto de 1384. Também na mesma região, D. Manuel doou ao seu contador João Caldeira três soutos de castanheiros no termo da Covilhã, os quais confrontavam, aliás, com vários outros soutos (HFAC, IV, doc. 82, pp. 85-86, de 21 de abril de 1497).

84 CHDJI, vol. III, t. 1, doc. 157, pp. 100-101, de Lisboa, 9 de junho de 1389.

85 CHDJI, vol. III, t. 1, doc. 38, p. 34, de Lisboa, 5 de abril de 1404. 
Tal como sucede na Itália, onde o fruto abundava, também para Portugal temos informações sobre o movimento comercial de castanhas, indício inequívoco de que, na Idade Média, o plantio do castanheiro e a presença do fruto na economia era já uma realidade integrada e sistematizada. Assim, sabemos que, no século XIII, pagavam a dízima ao rei as castanhas que entravam no porto de Atouguia ${ }^{86}$, ainda que desconheçamos de onde provinham e até onde seguiriam. As castanhas podiam-se comprar a regateiras no mercado de Santarém, como nos dão conta posturas confirmadas por D. Afonso IV em 1338 (CHDAIV, II, doc. 130), e no de Lisboa, em que as mulheres que as vendiam, juntamente com outros frutos secos (favas e ervilhas), deviam ter, como mandava a legislação local, medidas corretas (LPA, 58). Mas, inequivocamente, o comércio e consumo local era muito mais vasto, abrangendo todo o reino, já que entre os direitos da portagem que impendiam sobre a fruta, nos forais manuelinos, sempre a castanha se encontrava referida.

Já quando as carências alimentares sobrevinham, a castanha assumia um protagonismo que no geral não tinha fora das regiões produtoras. Nessas ocasiões figurava como um bem comercial de primeira importância, circulando por mais amplas distâncias. Assim aconteceu, em 1414, quando em terra de mouros havia escassez de cereal e os mercadores portugueses, procurando colher os melhores lucros com tal crise, fretaram navios no reino ou mesmo na Flandres, na Bretanha e em Inglaterra para levarem, até ao norte de África, cereal, castanhas, avelãs, nozes e outros mantimentos. No entanto, os interesses económicos dos comerciantes podiam fazer perigar o sustento da população. Dessa realidade nos dá conta a exposição sobre esta ocorrência levada até ao rei pelo concelho de Lisboa, alegando que, desse modo, o pão faltava no reino, o que seria tanto mais grave quanto por essa altura se preparava a expedição para Ceuta e era necessário ter provisões para o abastecimento dos navios ${ }^{87}$.

Outro episódio a confirmar o papel da castanha como bem alimentar de sustento básico teve lugar anos mais tarde. Quando houve fome em Lisboa e nas comarcas em redor, no ano de 1440, logo a castanha fez parte dos produtos a entrar na urbe, vinda em navios do reino ou estrangeiros, tendo então D. Afonso $\mathrm{V}$ isentado da dízima os cereais (trigo, cevada, centeio, milho e aveia)

${ }^{86}$ Notas do registo de D. Sancho (talvez D. Sancho II) e do rol de Soeiro Pais, almoxarife de D. Afonso III, o que nos remete para uma data crítica entre 1223?-1279 (DP, I, doc. 17, p. 12). Em 1255 as dízimas do que entrava e saía pela foz de Autoguia, explicitando-se madeira lavrada, castanhas, nozes e avelãs, pertencia ao alcaide, como o confirmou D. Afonso III, bem como lhe cabia a portagem do vinho exportado (CHDAIII, liv. I, vol. 2, docs. 710, 711, pp. 282-283, de Lisboa, 5 de junho de 1255).

87 D. João I proibiu de imediato este comércio de alimentos para terras marroquinas, bem como o de armas (CHDJI, vol. III, t. 3, doc. 1078, pp. 162-163, de 23 de março de 1414). 
e todas as favas, ervanços (grão de bico), píseos, noz, castanha e avelãs que viessem por mar à cidade (CPRDAV: 661-563).

No que se refere ao consumo da castanha, as inquirições fornecem interessantes particularismos tanto sobre o seu lugar na alimentação animal como humana. Na verdade, temos informação de que na freguesia de S. Miguel de Vilarinho (concelho de Santo Tirso) cada fogo dava ao rei uma cesta de castanhas e entregava ao mordomo uma outra para cevar um porco ${ }^{88}$. Por sua vez os foreiros de dois lugares em Santa Maria de Chorence (concelho de Terras de Bouro) entregavam ao mordomo duas cestas de castanhas para cevar dois porcos ${ }^{89}$. O mesmo acontecia nas freguesias de S. Martinho de Covide e de S. Paio de Carvalheira (concelho de Terras de Bouro), em que, para cevar os porcos, ao senhor da terra eram entregues, respetivamente, 12 ou 17 cestas de castanhas ou de landes ${ }^{90}$, percebendo-se como, em terra de castanheiros, a alimentação dos suínos se substituía pela mais comum do fruto dos sobreiros ${ }^{91}$.

Já os homens, ontem como hoje, gostavam de acompanhar a carne de porco com castanhas. Por isso se entregava, em muitos casos ao mordomo, em boa parte para seu alimento quando ia cobrar os foros e rendas, uma ou mais espáduas de porco com castanhas e, no geral, também acompanhadas de vinho ${ }^{92}$. Noutros casos, porém, constituía um foro que revertia para os celeiros régios ${ }^{93}$. Logo, a castanha constituía, nestes casos, um acompanhamento do conduto, aqui traduzido na carne de porco. Este contexto alimentar confirma o seu uso como substituto do pão, o mais tradicional e usual alimento básico (i.e. que serve de "base" da refeição). Não será ainda de excluir que a castanha pudesse acompanhar outras carnes, como, por exemplo, as de aves ${ }^{94}$ - prática que veremos perfeitamente atestada em livros de culinária da Época Moderna em diante.

Mas, tal como já identificámos para as fontes literárias antigas, a castanha também se cozinhava para servir de elemento central da refeição. A técnica de cozedura que vem atestada nas inquirições é a simples assadura. O interesse particular da nossa documentação consiste em dar uma visão da associação tradicional, no passado e no presente, do seu consumo associado à ingestão de vinho. De facto, os homens sabiam comê-las assadas em pleno inverno,

88 PMH, Inquisitiones, I: 91.

89 PMH, Inquisitiones, I: 95.

90 PMH, Inquisitiones, II, p. 97-98.

91 Com a expansão de castanheiros nos Apeninos, também de castanha se alimentam os porcos (Rao 2013: 220).

92 PMH, Inquisitiones; I: 79, 91 (certos homens das freguesias de S. Cristóvão de Guimarães e S. Miguel de Vilarinho de Santo Tirso pagavam: spatulam cum vino et castaneis).

93 PMH, Inquisitiones, I: 79, 80, 81, 82, 85, 88, 89, 90, 91, 95, 131, 145.

94 PMH, Inquisitiones, I: 112 (os herdadores de Santiago de Moldes, hoje um lugar da freguesia de Remelhe, concelho de Barcelos, davam “j frangão cum castaneis"). 
regadas com bom vinho, certeza do conforto do calor no corpo, primeiro nas mãos ao recebê-las a escaldar, e depois no estômago. Por isso, muito curiosamente, os moradores de Santiago de Chamoim (concelho de Terras de Bouro) davam por fossadeira 12 teigas de castanhas assadas até ao Natal e cinco cestas os de S. João de Balança (concelho de Terras de Bouro), bem como certas quantidades de vinho ${ }^{95}$. Igualmente na dura tarefa de vigiar o castelo, nos frios dias invernosos, os veladores dos castelos eram compensados com cestas de castanhas e cântaros de vinho ${ }^{96}$. E este mimo quente não seria mesmo desprezado pelos nobres, pelo que, quando o senhor da terra passasse por Santa Marinha de Covide ou S. Paio de Carvalheira (concelho de Terras de Bouro), deviam ser-lhe dadas teigas de castanhas assadas, vinho e, como vimos, porcos cevados com castanhas ${ }^{97}$. Não temos pois dúvida de que, em tempos medievais, o provérbio "no dia de S. Martinho: lume, castanhas e vinho" se transmutava numa promissora realidade. Na verdade, era pelo S. Martinho que um casal da freguesia de S. João de Bastuço (concelho de Barcelos) tinha de entregar, entre os seus foros, uma cabaça de vinho e um alqueire de castanhas verdes ${ }^{98}$.

As castanhas davam assim o tom à sociabilidade da família e da comunidade (Cherubini 1981: 278-280). Ontem como hoje, em Portugal como noutros espaços produtores europeus, o "verão" de S. Martinho (de Tours), a 11 de novembro, coincidindo com a apanha da castanha e com o vinho novo a correr da pipa, assume-se como uma das mais tradicionais festividades religiosas e populares ${ }^{99}$.

Esta simplicidade rústica, mais comum ou festiva, do consumo da castanha transmuta-se quando a castanha desce da montanha para a planície e atinge as cidades. A sua degustação entrava, neste caso, mais no campo do prazer e não tanto no da necessidade, ainda que também nessa circunstância a sua importância adviesse, em grande medida, da sua conservação, permitindo uma prolongada comercialização (Montanari 2012: 131). Desde então as castanhas já não eram só comidas cozidas, assadas ou fritas, como sobremesa no final da refeição ou acompanhamento de carne de porco ou de aves, mas também se cozinhavam em leite, em vinho, em sumo de laranja ou em açúcar e transformavam-se em doces mais refinados, próprios de gostos e culturas de requinte (Montanari 2012: 132-135).

95 PMH, Inquisitiones, I: 96.

96 PMH, Inquisitiones, I: 148 (os homens da freguesia de S. Martinho da Ribeira de Soaz, hoje freguesia de Ventosa, concelho de Vieira do Minho, entregavam aos veladores do castelo "singulas minimas cestas de castaneis et singulos cantaros vini").

97 PMH, Inquisitiones, I: 97-98.

$98 \mathrm{PMH}$, Inquisitiones, I: 111.

99 Sobre a associação do consumo da castanha ao mosto e vinho novo na península itálica, vd. Cherubini 1981: 279 . 
Fica já subentendido, pelo que atrás se refere, que a culinária visa não apenas matar a fome, mas também agradar ao gosto de quem come. Aliás essa relação direta de causa-efeito entre o prazer e o desenvolvimento da arte culinária tem origens clássicas, presentes quer nos escritos médicos atribuídos a Hipócrates, quer no pensamento filosófico de Platão ${ }^{100}$. A esses mesmos textos e autores remonta, igualmente, a noção de que o regime alimentar das pessoas com saúde é diverso do dos doentes. Mais ainda: o critério de distinção entre a "dieta saudável" e a "dieta terapêutica" reside no papel que desempenha o "prazer" (gr. hedonê) em cada um dos contextos. Ou seja, enquanto o cozinheiro orienta a sua arte para o prazer ${ }^{101}$, o médico, embora não anule as valências gustativas dos seus preparados (até porque constituem um estimulante essencial do apetite), está subordinado ao princípio de fazer "o melhor" (que em linguagem médica é sinónimo de "o mais saudável”"102). Dentro desta lógica, a literatura técnica culinária deve ser tida como fonte escrita prioritária para indagarmos a pegada literária gastronómica da castanha, conscientes do diálogo que lhe subjaz com o discurso médico. Procederemos a essa leitura de seguida, no ponto 2 da nossa análise.

\section{A CASTANha: um PRAZER DA MESA EM dí́logo COM as NORMAS DIETÉTICAS}

Impõe-se começar por compreender que, até ao séc. XVIII, não havia uma distinção muito rígida entre alimento e medicamento. $\mathrm{Na}$ verdade, antes da consolidação dos paradigmas científicos modernos nos domínios da química e da fisiologia experimental, verifica-se a existência de um diálogo estreito entre a culinária e a medicina. Para essa proximidade e inter-relação dos conhecimentos do cozinheiro e do médico chamaram já a atenção vários estudiosos, cobrindo os grandes períodos da Idade Média ${ }^{103}$, do Renascimento ${ }^{104}$

100 No tratado hipocrático Da medicina antiga (5.2) afirma-se que o que caracteriza o regime de vida das pessoas com saúde é esse ser regido pela satisfação do prazer (o que em termos alimentares implica o predomínio do gosto na arte culinária). Por outro lado, no diálogo de Platão Górgias (521e), a personagem Sócrates, veiculando a opinião comum ao seu tempo, contrapõe os preparados confecionados pelos cozinheiros aos prescritos pelos médicos, apelidando a mesa dos primeiros de mesa "repleta de maldades" e a dos segundos de mesa "repleta de delícias". Sobre o diálogo entre prazer e saúde em textos médicos hipocráticos e filosóficos de Platão, vd. Soares 2018b.

101 Vd. o seguinte trecho do tratado Da medicina antiga (5.2): "Realmente ainda hoje todos quantos não fazem uso da medicina, os Bárbaros e alguns Gregos, vivem o mesmo regime que as pessoas de saúde, em função do prazer, sem se privarem de nada que desejem e sem terem de se conter" (trad. e sublinhado nosso).

102 Dessa correspondência entre "o melhor" (gr. tò béltiston) e "o mais saudável" (gr. tò hygieinóteron) nos dá conta Platão, no diálogo Alcibiades (1.107c).

103 Vd. Montanari 1988; Flandrin 2001; Scully 1995a; 1995b; Laurioux 2006.

104 Vd. Albala (2002), autor que diz não ser possível precisar se foram as teorias humorais 
e da Época Moderna ${ }^{105}$. No entanto, convém ter presente que esta não deixa de ser, como bem alertou Bruno Laurioux (2006: 224), uma "questão espinhosa". Ao contrário de outras vozes, o medievalista francês assume uma posição em que considera mais plausível ter sido o discurso médico a acompanhar as tendências ditadas pela prática culinária e não o inverso (idem: 230) ${ }^{106}$. Sem pôr em causa a evidência apontada pelos seus predecessores nesta área de estudo para a existência, em textos com informações culinárias (além dos livros de receitas, correspondência pessoal e literatura de viagens), de uma "coerência com as teorias dietéticas" (idem: 227), Laurioux sublinha que esse facto não é uma evidência de que a dietética determinou a culinária, mas sim de que constitui um princípio organizador (idem: 230). Não obstante divergências pontuais, é voz consensual entre os especialistas que a rutura entre medicina e culinária se deu apenas nos sécs. XVIII-XIX. Só quando os alimentos deixam de ser analisados pelos efeitos que têm no indivíduo e passam a ser distinguidos pelas suas propriedades físico-químicas e nutricionais é que podemos afirmar que se abandonou plenamente o paradigma clássico de matriz hipocrático-galénica.

Importa, ainda, ter presente que não é necessário os textos de natureza predominantemente culinária conterem referências explícitas a valências medicinais para que se admita que elas lhes subjazem. Não se pode igualmente descurar o papel que teve a transmissão oral na divulgação dos princípios dietéticos, realidade difícil de detetar (por ausência de testemunhos), mas que, sem dúvida, terá contribuído para a popularização dos conhecimentos médicos e sua disseminação fora dos circuitos das elites (primeiras consumi-

dos dietistas a moldar as práticas alimentares ou se aqueles simplesmente se acomodaram às cozinhas da época.

105 Para uma síntese dos estudos marcantes nesta matéria, vd. Asfora (2014: 181-193). $\mathrm{O}$ estudo desta historiadora tem o particular interesse de se debruçar sobre um período da medievalidade que não recebera a atenção dos restantes especialistas, a Alta Idade Média (sécs. V-IX). O propósito da autora reside em explicar o porquê de o "livro de cozinha de Apício" (De re coquinaria) ter sido tão copiado durante os sécs. VIII-IX. A sua investigação permitiu-lhe demonstrar que esse interesse se ficou a dever ao facto de, nessa obra, não só abundarem os ingredientes que integravam os textos sobre "matéria médica" (ou seja, obras em que se descrevem as propriedades medicinais de plantas, animais e minerais), mas também apresentarem numerosíssimas receitas de molhos (usados para "temperar", o mesmo é dizer, para combinar as propriedades naturais de cada ingrediente de forma a obter um certo equilíbrio humoral da comida). Em suma, o texto latino de Apício não deve continuar a ser interpretado somente como um livro de receitas de cozinha, mas como um livro de cozinha com sentido higienista (manter a saúde) ou terapêutico (estabelecer a cura).

106 Os principais argumentos adiantados pelo estudioso para esta visão são os seguintes: médicos medievais escreveram livros inteiramente dedicados a receitas para doentes (a que chama de "cozinha médica"), o que evidencia o seu desígnio de satisfazer os gostos dos doentes, sem descurar as exigências da dietética (idem: 236); há evidências de livros de culinária nas bibliotecas de alguns médicos (idem: 238). 
doras dos serviços dos profissionais de medicina, assim como dos da cozinha elevada ao estatuto de arte culinária ${ }^{107}$ ). Passaremos, de seguida, à análise das fontes culinárias portuguesas, munidos do pressuposto teórico de que até ao séc. XVIII (inclusive) a coabitação no alimento das valências gastronómica e medicinal era uma realidade. A confirmação da veracidade desta "leitura" é-nos dada, como teremos ocasião de assinalar, pela presença em tratados de dietética de referências diretas à existência de pressupostos médicos por detrás dos modos de preparação culinária da castanha.

Antes de procedermos à utilização dos livros de culinária (manuscritos e impressos) como documentos para o rastreio da pegada literária da castanha no discurso culinário português ${ }^{108}$, convém sintetizar as limitações com que se defronta o historiador ao recorrer a esta documentação. Do ponto de vista metodológico, e reportando-se a documentação medieval (mas cuja problemática é válida para algumas obras de períodos posteriores), Allen Grieco (1992) levanta os questionamentos mais pertinentes que coloca semelhante documentação: o facto de uma receita ter sido passada a escrito não atesta estarmos perante receitas "reais" (que foram preparadas, servidas e consumidas); até que ponto a literatura culinária reflete a prática culinária; qual o perfil sociológico dos consumidores (admitindo-se que o receituário é "real”); quais os contextos de preparação e consumo (prática do quotidiano, de ocasiões excecionais ou de cura); qual a frequência de preparação (regularmente, pouco ou nunca confecionadas). Em suma, os livros de culinária são, como bem alertou Bruno Laurioux (1997: 464), "fontes lacunares", que só adquirem maior legibilidade quando analisadas em conjunto com outras obras do mesmo tipo e cruzadas com fontes de outra natureza (iconográfica e arqueológica, para o período que tem em conta, a Idade Média).

De interesse para a nossa reflexão é também a mais recente proposta de leitura de Ken Albala (2012) para abordar os livros de culinária como documentos históricos. $\mathrm{O}$ autor considera o universo literário contemporâneo e a sua análise alerta-nos para as "cautelas" a ter perante fontes que - por serem datadas, assinadas e, muitas vezes, com dados explícitos sobre motivações da escrita e público-alvo - têm a aparência de mais fiáveis do que as

107 Usamos o termo culinária na aceção clássica de "conjunto de conhecimentos especializados (tékhne ou epistême)" cuja posse identifica uma categoria profissional específica, genericamente designada de cozinheiro. Sobre a discussão que na Grécia clássica a questão gerou nos circuitos filosóficos (em particular veiculada por Xenofonte, Platão e Aristóteles), vd. Soares 2012. Para as nuances do conceito e sua evolução desde a Antiguidade aos nossos dias, leia-se o estudo de Bruno Laurioux neste livro.

108 Adotamos, nesta análise separada das valências gastronómica e médica do alimento, a metodologia indicada por Laurioux (2006: 225) para distinguir os universos culinário e médico, ou seja, a produção de documentação diversa: os livros de cozinha (valência gastronómica) e as obras de dietética (valência dietética). 
suas antepassadas (no geral mais lacunares). Ao historiador não cabe fazer essa "leitura ingénua" do livro de cozinha, mas sim uma "leitura crítica", de que destacamos as suas recomendações metodológicas mais pertinentes: a existência de autor, lugar e data de publicação não inviabiliza a possibilidade de estarmos perante cópias e adaptações de textos anteriores (pelo que a data de publicação não deve ser tomada por cronologia de criação da receita, nem o local de edição por território do receituário); por se tratar de literatura prescritiva (retrato das aspirações do autor e das suas expetativas quanto ao que o leitor quer saber) não espelha a prática culinária (o que realmente se comia em determinado contexto). Claro que, como bem observa Albala, estas "limitações" não retiram interesse histórico aos livros de culinária. Estamos, sim, perante narrativas de interesse histórico bastante variado, que devem ser complementadas por fontes de outras naturezas. Delas retiramos informações sobre economia (produtos e sua disponibilidade no mercado), cultura material e tecnologia (utensílios, equipamentos e métodos culinários), sociologia, política e cultura.

Conscientes da complexa "ficha de leitura" que o escrutínio da análise histórica aos livros de cozinha impõe, e atendendo ao objetivo da presente pesquisa de traçar o papel da castanha na alimentação portuguesa na longa duração, tivemos de proceder a um estudo não de tipo exaustivo, mas prospetivo. Assim, o que nos propomos fazer não é uma análise descritiva individualizada de cada documento, respondendo, para cada um, ao questionamento amplo que o mesmo coloca. Teremos, no entanto, em conta os dados que ajudem a explicar o lugar que o receituário da castanha ocupa em cada em deles. Procedemos ao levantamento sistemático das receitas num corpus de obras que abrange os sécs. XVI a XXI. Esta recolha, apesar de não ter sido exaustiva para a Época Contemporânea, contempla as obras que marcaram o panorama editorial do séc. XX e que, nas primeiras décadas do séc. XXI, revelam a preocupação de resgate de um produto que procura afirmar-se no mercado, tanto da gastronomia tradicional, como da culinária gourmet e da cozinha saudável.

Assim, o universo da literatura culinária que teremos em conta inclui cinco manuscritos, dez livros impressos e dois periódicos. O recorte efetuado obedeceu aos seguintes critérios: só se consideraram os manuscritos publicados; os livros impressos selecionados, para os sécs. XVII a XIX, são aqueles que incluem referência à castanha (a influência francesa ao longo deste período levou, ainda, ao cotejo com três obras clássicas impressas em França), o que totaliza metade da nossa amostra; para os sécs. XX e XXI, foram consideradas obras que atestam o determinismo exercido por fatores de ordem política, social, económica e ideológica na publicação de coletâneas de receitas de cozinha; no domínio do periodismo culinário analisámos as duas obras pioneiras no panorama português, publicadas com um intervalo 
superior a um século, mas cuja relação de "parentesco editorial" a diretora da segunda delas, a Banquete, faz questão de assinalar ${ }^{109}$.

Porque a análise do corpus estudado pôs em evidência, para a Época Moderna e para a Contemporânea, discursos em que prevalecem tónicas distintas, subdividimos este ponto 2 em alíneas autónomas. $\mathrm{Na}$ primeira, o relevo recai sobre o diálogo entre gastronomia e dietética; na segunda, sobre o resgate da memória gustativa dos antepassados (a chamada "cozinha tradicional") e outras tendências culinárias (que designamos, por contraste, de "novas cozinhas").

\section{I. Consumo de castanha no Portugal moderno: gastronomia E DIETÉTICA}

O levantamento efetuado permitiu-nos identificar um "receituário fundador", estabelecido com base no critério cronológico e na permanência na longa duração ${ }^{110}$. É por este núcleo primordial que iniciaremos a nossa análise. Teremos sempre presentes as conclusões que a documentação anterior permitiu já apurar em termos de produção e de acessibilidade à castanha. Porque os silêncios, em história, têm tanta (ou mais) importância do que as falas (neste caso, em que lidamos com livros, seria mais correto dizer as escritas), impõe-se começar por refletir sobre a ausência do fruto naquele que, até à data, é tido como o mais antigo "livro de cozinha" português.

Trata-se de um manuscrito de autoria anónima, dado como pertencente à Infanta D. Maria (1538-1577), neta do rei D. Manuel I. Publicado por Salvador Dias Arnaut e Giacinto Manuppella em 1967, o codex I. E. 33 da Biblioteca de Nápoles é considerado um repertório da cozinha medieval servida à mesa régia. Confirmada pelas fontes atrás analisadas como fruto de subsistência e de sustento essencialmente dos grupos sociais mais humildes, não é de estranhar que a castanha não tivesse sido escolhida pelas mãos que redigiram um livro destinado a um membro da mais alta hierarquia social. Daqui não se infere, e disso nos deu conta a documentação medieval atrás considerada, que as classes mais altas não comessem castanhas. Infere-se, simplesmente, como bem alertou Jeffrey Pilcher (1997: 208) a propósito da literatura culinária nacional mexicana do séc. XIX, que o receituário popular tendencialmente não figura em obras escritas por ou para as elites.

\footnotetext{
109 No n. 2 (abril 1960: 9) publica-se o frontispício do n. 1 da revista Annona, a que chamou Maria Emilia Cancella de Abreu, no sumário da sua revista: o mais antigo dos "avós" de "Banquete".

110 O nome desta categorização deriva do facto de, do ponto de vista cronológico, essas serem não só as receitas mais antigas, mas também por permanecerem na atualidade, ainda que necessariamente adaptadas.
} 
Ao invés, no manuscrito 142 do Arquivo Distrital de Braga (Barros 2013), de proveniência monástica e, como tal, reproduzindo um quotidiano mais modesto, ainda que aberto às delícias das épocas festivas, deparamos com uma receita (n. ${ }^{\circ}$ 97) que agrega três formas distintas de preparação culinária da castanha. A autoria do manuscrito permanece uma questão sobre a qual não nos debruçaremos111, até porque, o dado de relevo para o nosso estudo não se altera, visto que diz respeito a uma culinária relativa a uma comunidade religiosa masculina. Ou ${ }^{\text {tro }}$ elemento a ter em conta é a data de composição. Por se tratar de um texto que denuncia várias mãos na sua escrita, é mais prudente tomar este manuscrito como um exemplar cuja memória e redação original remontam ao séc. XVI, mas de fixação mais provável no séc. XVII. Considerando, ainda, que os livros de culinária constituem veículos de transmissão oral de um património de origem num passado impossível de determinar, conhecimento esse acomodado pelo respetivo redator à sua circunstância, estas são sempre fontes escritas que, mesmo datadas, refletem um "estado da arte" anterior. Ou seja, a receita do m. $142 \mathrm{ADB}$ fixa práticas que já vinham de trás. Tanto assim é que nela se descrevem os dois métodos de cozedura tradicionais do fruto: cozidas e assadas ${ }^{12}$. Atentaremos nas informações pertinentes para melhor conhecermos o estádio do conhecimento técnico culinário atingido.

Repare-se que o ponto de maturação do fruto determina a preferência por determinado método, uma vez que para as castanhas "verdes" se indica a cozedura simples, em água e sal. Quanto aos métodos de assadura, a que se sujeitam as castanhas amadurecidas ${ }^{113}$, já são aqueles que ainda hoje se praticam:

111 O manuscrito foi alvo de duas publicações em Portugal, divergindo as respetivas editoras-autoras na atribuição de autoria e datação (dados que não constam do manuscrito). Enquanto Anabela Leal Barros (2013: 14-37) argumenta no sentido de se tratar de um frade ligado a um Colégio Universitário de Coimbra, o Real Colégio de Nossa Senhora da Conceição da Ordem de Cristo (por isso vulgarmente conhecido por Colégio de Tomar) e situar a sua escrita inicial no séc. XVI, já Sara Claro (2013: 137-142) considera mais provável tratar-se do prelado de Tomar Luís Álvares de Távora (séc. XVII), retratando o manuscrito a realidade do mosteiro beneditino de São Martinho de Tibães. Mais recentemente, por ocasião do estudo e publicação do caderno II desse mesmo manuscrito 142 do Arquivo Distrital de Braga, A. L. Barros retoma a questão da autoria e datação do texto, propondo que a datação (de grande parte) das receitas é dos finais do séc. XVI, mas que a cópia a limpo, aquela que possuímos, é sim da autoria do referido prelado (Barros 2016: 17-18).

112 As referências a práticas culinárias aparecem dispersas em muita outra tipologia de documentação que não os livros de cozinha. Não a tivemos em consideração no nosso estudo, que, por opção metodológica, se centrou nos documentos técnicos de cozinha e medicina, mas, ainda assim, gostaríamos de, a título ilustrativo, registar, para a castanha, a pertinência de outros textos. Refira-se, para os finais do séc. XVI, a obra do colono português no Brasil Gabriel Soares de Sousa (Notícia do Brasil, 1587), que, na tentativa de, pela analogia, dar a conhecer aos seus conterrâneos o fruto do amendoim, escreve: "comem-se assados e cozidos com casca como as castanhas e são muito saborosos" (Albuquerque-Pericão 1986: 120).

113 Depreende-se ser esse o seu estado de maturação, uma vez que, quando primeiro se mencionou as cozidas, expressamente se declarou a seguinte condição: "se são verdes...”. 
sob o fogo, na cinza (o chamado "borralho"), e no forno. A presença de uma indicação valorativa para a sua preparação na cinza do brasido denota que era intrínseca à preparação culinária a consciência das valências gustativa e medicinal da comida. Dizer "também se fazem de borralho, e são melhores"114 pode significar tanto que "sabem melhor" como que "fazem melhor". Considerar que o duplo sentido está contido nessa adjetivação parece-nos a interpretação mais concordante com aceção medieval (atribuída ao mais popular médico árabe de então, Avicena) de que "o que sabe bem faz bem"115.

Do ponto de vista das indicações técnicas, repare-se no grande detalhe descritivo em relação ao método de assar sob o lume. Nestas indicações, o autor da receita detém-se tanto em informações sobre as matérias-primas usadas para fazer a fogueira ("lenha delgada como silvas, sargaços, carquejas, etc."), nos cuidados a ter para não arruinar a preparação ("revolvendo-as [as castanhas] que se não queimem") e na finalização, indispensável ao sucesso da receita ${ }^{116}$. Ficamos também a saber que já é bastante tradicional a acima evocada prática de pisar (ou "amossegar" ${ }^{117}$, como se lê no manuscrito) os frutos antes de os levar ao forno ${ }^{118}$.

Há nessa receita 97 outras duas menções a preparados culinários em que se percebe o continuum culinário desde a recuada Antiguidade, evidente na cozedura das castanhas com vários temperos. Um preparado é mais simples e de cozedura rápida; o outro mais complexo e demorado. No primeiro caso trata-se de "castanhas engroladas" ${ }_{119}$, que se comeriam de meia cozedura, fervidas em pouca água ("com água quanto as cubra") e apenas temperadas de sal e de uma planta em particular, a erva-doce. $\mathrm{Na}$ outra forma de as comer cozidas, aumentar-se-ia significativamente a quantidade de água, ao que se deduz do nome dado ao preparado: "caldo de castanhas". De facto o substantivo "caldo" indica estarmos perante um preparado de consistência líquida, consumido quente, com a particularidade de se lhe juntar uma grande diversidade de temperos - desde os mais comuns adubos (azeite e sal), às aromáticas autóctones (salsa, cebola e erva-doce) e uma especiaria cara importada (açafrão ${ }^{120}$ ). Verifica-se a presença nas duas receitas da erva-

114 Usamos a grafia modernizada pela autora da publicação do manuscrito (Barros 2013).

115 Laurioux (2006: 238) reproduz em francês essa máxima atribuída a Avicena, que se traduz para português: "o que tem bom gosto alimenta melhor, porque os alimentos que comemos com prazer serão bem recebidos no estômago [ao passo que] os alimentos comidos sem prazer não se digerem bem".

116 "[...] e depois de assadas, no mesmo rescaldo abafadas com sargaços, ou fétãos verdes, ou com terra por um espaço" (Barros 2013: 213).

117 Bluteau I (sub verbum Amocegar) indica que significa ter mossa ou golpe.

118 Cf.: "Assam-se também no forno amossegandoas primeiro".

119 Bluteau III (sub verbum Engrolado) indica significar "Mal cozido, ou meyo crua, \& meyo cozida".

120 Sobre o papel do açafrão na alimentação e medicina durante a Antiguidade, vd. Dalby (2000: 
-doce, coincidência que não deverá apontar, como se poderia pensar, para uma escolha ditada (exclusivamente) por critérios gastronómicos.

$\mathrm{Na}$ verdade, conforme temos insistido, não se deve reduzir a interpretação destas listas de ingredientes a uma mera evidência culinária (que não deixam também de ser). Nem tão pouco interpretá-las simplesmente como testemunho do papel que o prazer (gustativo) desempenhava nas práticas culinárias, dando à cozinha a dimensão gastronómica que ela, a partir do momento em que convoca o gosto, sempre tem. Todos esses ingredientes remetem para a prática de uma técnica, para o gosto e para a saúde. O papel dos temperos na confeção culinária, sob o ponto de vista da dietética até ao séc. XVIII, é o de reguladores do equilíbrio de um prato ${ }^{121}$. É certo que a receita do manuscrito $142 \mathrm{ADB}$ nada refere sobre a determinação que algum princípio médico poderia ter exercido na escolha dos temperos das castanhas cozidas. Mas o cruzamento deste preparado com as informações encontradas no livro do médico de D. João V, Francisco Fonseca Henriques, Ancora medicinal para conservar a vida com saúde (1721), permite confirmar a presença em texto de teor culinário de princípios dietéticos (se não teóricos, pelo menos) empíricos, veiculados por via oral e popular.

Autor da viragem do séc. XVII para o XVIII (n. 1665 - m. 1731), Francisco de Mirandela (cognome da sua naturalidade, pelo qual ficou mais conhecido) dá conta de como os médicos (conhecedores e praticantes da medicina erudita, ou seja, letrada) conheciam a prática culinária, pois a ela se refere expressamente na sua entrada "castanhas" do cap. XVII - Dos frutos lignosos, secção III - Dos alimentos em particular $(1721: 361)^{122}$. Que o médico se refere a um conhecimento dietético de cariz popular, depreende-se do recurso ao sujeito indeterminado, contido na forma verbal com que abre o seguinte trecho:

Dizem que a sua flatulencia se emenda cozendoas com erva doce: mas o certo he, que a ellas nada se lhe communica da erva doce.

Da observação que a seguir tece deduz-se que o médico é sensível ao relevo das questões gastronómicas (isto é, que valorizam o papel do prazer gustativo) nas escolhas alimentares da população comum:

Assadas, ou cosidas sem casca, saõ menos flatuosas, porèm ficão com

138-139). Quanto ao seu uso na culinária da Época Moderna portuguesa, leia-se Gomes (2016: 67-68).

121 Como alerta Asfora (2014: 182) e procurou demonstrar Scully (1995b), posição de que discorda Laurioux (2006: 228-229), só com o séc. XV o verbo latino temperare começa a esvaziar-se do seu sentido dietético de combinar as propriedades dos vários alimentos de forma a harmonizar os humores do prato final, ajustando a "compleição" da comida à "compleição" ou "temperamento" do comensal.

122 Este caso é um bom exemplo a confirmar a justeza da interpretação de Bruno Laurioux (2006) sobre terem sido os médicos a adequar o seu discurso à prática culinária e não o inverso. 
menos gosto.

Este passo tem, para o que ao "receituário fundador" diz respeito, a importância acrescida de sugerir que dois dos métodos consagrados no livro de receitas do m. $142 \mathrm{ADB}$ teriam sido aí incluídos sobretudo por razões dietéticas.

Mirandela ecoa no seu texto ainda a matriz clássica, perpetuada nas épocas medieval ${ }^{123}$ e moderna, que considerava a castanha um alimento indigesto, cujas dificuldades digestivas se traduzem em flatulência, prisão de ventre e sofrimentos estomacais. No entanto, esse é um alimento para o qual o médico continua a reconhecer a virtude de ser altamente nutritivo, quando consumido em fresco, conforme se depreende da confrontação entre o que escreve no início e quase no termo da rubrica sobre as castanhas:

Cozem-se muyto mal no estâmago, saõ indigestas, \& flatulentas, mas nutrem copiosissimamente. [...] As secas saõ mays indigestas, \& nutrem menos.

A confirmação de que o "receituário fundador" da castanha reside em prepará-las assadas ou em comê-las cozidas chega-nos pela permanência, até à atualidade, destas formas de confeção. Porém nos livros de cozinha, em geral, apenas figuram receitas que envolvem preparações que exigem técnicas elaboradas, pelo que deixam de aparecer receitas para assar e cozer castanhas. Esses seriam saberes que, pela sua simplicidade, eram tidos como conhecimentos universais, pelo que dispensavam o registo para memória futura. Já para a preparação de castanhas em caldo ou sopa encontramos a sua pegada escrita até ao séc. XXI. Conforme alertámos acima, o questionamento que o historiador coloca às fontes consultadas é multifacetado, revelando aspetos sociais, políticos, económicos e culturais. A contextualização de cada uma das obras revela-se essencial a esse respeito, pelo que não isolaremos a perceção do desenvolvimento técnico do receituário da castanha desse enquadramento histórico.

Do séc. XVIII é o códice 11390 da Biblioteca Nacional de Portugal, compilado pelo franciscano frei Manuel de Santa Teresa e escrito por várias mãos, segundo Isabel Drumond Braga, autora do seu recente estudo e publicação ${ }^{124}$. Insere-se esta obra destinada aos franciscanos da província dos Algarves, bem como o manuscrito acabado de analisar e o que consideraremos de seguida, o n. 2403 dos Manuscritos da Livraria do Arquivo Nacional da

123 A título exemplificativo, recorde-se o testemunho do médico português Pedro Hispano, que, no Tesouro dos Pobres, as considerava úteis para o excesso do fluxo do ventre (Latim $\mathrm{Me}$ dieval: 184). Já no Livro sobre a Conservação da Saúde, se por um lado as julgava nocivas para os pulmões, pelo outro anotava que faziam bem ao fígado (Latim Medieval: 462, 466).

124 Veja-se o estudo que apresenta deste manuscrito e do manuscrito das freiras da Ordem da Visitação de Santa Maria, ambos publicados e analisados na mesma obra: Braga (2015: 41-84). 
Torre do Tombo (este quase totalmente redigido por uma só mão e pertença das freiras da Ordem da Visitação de Santa Maria, ou Visitandinas), na tradição europeia dos "Livros de Segredos". Neles encontramos quer receitas de culinária, como de cosmética e de saúde e conselhos vários de economia doméstica. Ou seja, são exemplares que confirmam como a "cozinha", lato sensu, era entendida como um espaço de confeção que envolvia manipulação e preparação de alimentos, tanto para fins alimentares, como de tratamentos vários (mezinhas e cosméticos) ${ }^{125}$. As referências internas a figuras e lugares conhecidos na cidade de Lisboa possibilitaram à referida historiadora datar o manuscrito das Visitandinas de finais do séc. XVII e primeira metade do séc. XVIII. No entanto, o que o seu estudo lhe permitiu concluir foi que o receituário teria sido formado pelos contributos que as freiras francesas e portuguesas, que estiveram na sua fundação (em 1784), quiseram dar à nova comunidade, não devendo, por isso, as ditas receitas ser tomadas por criações daquele convento de Lisboa (Braga 2015: 62-63).

Quanto à caracterização sociológica dos potenciais consumidores das receitas destes manuscritos e da origem desses receituários convém lembrar que é impossível estabelecer proveniências exatas (tanto geográficas como sociais). O que o estudo comparativo entre estes dois manuscritos e outras obras manuscritas e impressas levado a cabo por Isabel Drumond Braga permitiu apurar é que há bastantes cópias, dificultando a certeza de catalogar de originais aquelas para as quais (ainda) não se encontrou paralelo escrito. Por outro lado, parte da população das comunidades religiosas, tanto masculinas como femininas, provinha de famílias da aristocracia, donde se pode concluir que a "mesa" mais elaborada e rica de algumas dessas receitas revela os gostos e os hábitos requintados de uma elite social, seja ela leiga ou religiosa.

Estes dois manuscritos de casas religiosas portuguesas contemplam seis receitas que interessam ao nosso estudo: três de pratos salgados e outras tantas de doces. No Livro Arte de Cozinha para se governarem os que curiozamente quizerem guizar, compilado por frei Manuel de Santa Teresa, deparamos com dois preparados que entroncam no "receituário fundador" do caldo de castanhas. O primeiro deles, castanhas cozidas de caldo (fol. 15, Braga 2015: 123), é muito coincidente com a já atrás mencionada r. 97 do m. 142 ADB. Destacamos a permanência da referência à erva-doce, pelo que esta revela do diálogo entre cozinha e medicina. O segundo preparado tem para com este a novidade de ao caldo se acrescentar arroz, diferença patente de imediato no título castanhas com aros levão (fol. 15, Braga 2015: 123). Veremos, em

125 Como observa Braga (2015: 83): "Culinária, cosmética e farmacopeia eram três matérias que tinham como palco as cozinhas das casas e que se produziam a partir das heranças de conhecimentos de alimentação e saúde antigos, elaborados e reelaborados de acordo com as práticas e as integrações de novos produtos". 
livros de culinária publicados nos sécs. XX e XXI, este enriquecimento do caldo pelo acrescento de um cereal perpetuar-se na memória gustativa dos Portugueses, admitindo por variante de substituição o feijão, assunto que retomaremos mais adiante.

Deparamos, ainda neste manuscrito, com outras duas receitas que incluem castanhas: uma salgada (olha podrida) e outra doce (castanhas de outro modo em potagem ${ }^{126}$ ). Ambas são reveladoras de aspetos permanentes da culinária portuguesa. A primeira evidencia a sua permeabilidade a influências estrangeiras; a segunda o aproveitamento que esse fruto, desde logo pela sua natureza doce, irá ter na confeção de preparados de doçaria.

Que as castanhas combinam com carne já o demonstraram as fontes medievais analisadas ${ }^{127}$ e confirma-o a receita de olha podrida (fol. 79v.-80, Braga 2015: 212). Esta receita (de um cozido de carnes e legumes) corresponde à versão descrita por Rafael Bluteau no seu Vocabulário PortuguezLatino (1712-1728). A entrada do dicionário setecentista (vol. VI: 56) é particularmente interessante, quer por confirmar a origem espanhola deste prato em concreto ${ }^{128}$ (pois recorre a um dicionário castelhano para explicar o significado de "podrida"), quer por confirmar estarmos perante um prato da mesa dos ricos.

Em termos de doces, as três receitas registadas, do ponto de vista técnico, correspondem a preparações culinárias recorrentes na doçaria: os doces de colher, a fruta coberta e os "doces miméticos" ${ }^{129}$. Se atentarmos nos procedimentos culinários adotados e os relacionarmos com o contexto social dos respetivos autores, acreditamos poder depreender dessa relação um sentido sociotécnico para cada receita. Explicando melhor: as castanhas em potagem (fol. 16, Braga 2015: 124) afiguram-se uma versão doce do que poderia ser um ensopado em caldo de castanhas, acompanhado de adubos e aromáticas comuns nos pratos salgados (vinagre, perrexil, hortelã e coentros verdes). No fundo estamos perante a variante doce de uma potagem salgada, em que a natureza doce do fruto estimula o seu aproveitamento para um creme de castanhas pisadas com esses condimentos e enriquecidas com mel e especiarias (com particular destaque para a canela) de modo "que fiquem bem doces e

126 Potagem vem do fr. "potage" e do lat. "potare" ("embeber, beber"), segundo Bluteau (vol. VI: 651, sub verbum Potâgem) e aplica-se a preparados em que fatias de pão são embebidas em caldo. De facto, na receita em apreço, um dos ingredientes é pão torrado, embebido em vinagre.

127 Cf. supra ponto 1.2.

128 Que havia outras variedades nacionais de "olhas" confirma-o o manuscrito do frei Manuel Tereso, uma vez que no seu receituário inclui, além de outras, uma olha franceza e uma olha castilhana (Braga 2015: 212-213).

129 Denominação que atribuímos aos doces cuja morfologia imita uma determinada realidade. Neste caso, a receita não tem por ingrediente as castanhas, mas, graças à forma em que é moldada a massa que vai cozer ao forno, recebe o nome de castanhas. 
enxutas não muito e pretas ou pardas”. Seguramente, a consistência proposta e a indicação de que são servidas em pratos apontam para a categoria moderna dos chamados "doces de colher". A inclusão desta receita num manuscrito que retrata a cozinha de uma ordem masculina franciscana, em que são muito pouco expressivos os preparados doces ${ }^{130}$, explica, a nosso ver, a familiaridade deste doce com as técnicas gerais da preparação dos ensopados.

Já as receitas constantes do manuscrito das freiras Visitandinas permitem vislumbrar o esmero das mãos femininas na confeção de mimos doces e uma eventual ligação à origem francesa de algumas das irmãs fundadoras do convento em Lisboa ${ }^{131}$. As iguarias em apreço são Receita de Castanhas (fol. 72, Braga 2015: 349) e Broinhas de Ovos Molles e Castanhas (fol. 11, Braga 2015: 332-333). Sob o primeiro título descreve-se a preparação de castanhas cozidas inteiras em açúcar e posteriormente colocadas a secar em rede, depois de cobertas com açúcar. Embora não possamos determinar com segurança que esta técnica foi introduzida pelas freiras francesas, não deixa de ser interessante notar que a complexificação do procedimento de cozedura e secagem de castanhas cobertas dará lugar na literatura culinária portuguesa posterior à identificação das castanhas cobertas com as "marrons glacés” francesas ${ }^{132}$. Quanto à receita de Broinhas de ovos-moles, ela implica uma técnica apurada de pontos de açúcar e junção de gemas, em etapas sucessivas de preparação a quente e a frio, por forma a obter uma massa moldável. O facto de se dar às pequenas broas a forma de castanhas atesta o apreço que o fruto tinha entre uma população cuja memória gustativa do doce se alicerçava em ingredientes de presença sazonal à mesa. Ou seja, a castanha era a tal ponto um fruto apreciado, que se mimetizou sob a forma de um doce, em receituários posteriores justamente conhecido por "castanhas de ovos".

Tal como sucede com o livro de receitas das freiras Visitandinas, também o manuscrito das freiras Bernardas do convento de Odivelas, datado do séc. XIX mas retratando uma tradição anterior, é dedicado maioritariamente a receitas de $\operatorname{doces}^{133}$. Dessa obra fazem parte dois exemplares que reforçam o requinte a que

130 Como esclarece Braga (2015: 48), neste manuscrito as receitas doces correspondem apenas a $7 \%$ do total, ao passo que no manuscrito das freiras Visitandinas equivalem a $84 \%$ (eadem, ibidem: 65).

131 Casa fundada a 29 de janeiro de 1784 por uma comunidade religiosa franco-portuguesa (Braga 2015: 63).

132 É num livro dos anos 30 do séc. XX - A Doceira Familiar de Clara T. Costa - que surge, pela primeira vez, a denominação "castanhas cristalizadas”, dada como alternativa à designação portuguesa herdada do séc. XIX “castanhas cobertas”, o qual, como a própria esclarece no termo da sua receita, mais não é do que a tradução portuguesa para o afamado doce dos franceses, conhecido por "marrons glacés" (p. 49).

133 O texto é datado de finais do séc. XIX, uma vez que a sua proprietária, a monja D. Carolina Augusta de Castro, o deixou por morte (1886) à afilhada, tendo voltado, mais de um século depois, ao seu espaço original, pelo que se encontra hoje no museu do Instituto de Odivelas. Não 
chegou a doçaria conserveira dentro dos conventos. Sob o nome de castanhas doces (r. 158, Cabral 2000: 125) surge uma receita de castanhas cobertas muito idêntica à das Visitandinas (embora não haja menção à secagem sobre rede). Falamos de requinte e não devemos esquecer que o mesmo decorre também do prazer estético (e não apenas o gustativo) provocado pelo prato. Esse deleite visual parece ter estado na idealização de outra morfologia mimética associada à castanha, conforme se depreende da r. 109, de seu título castanhas em doce (Cabral 2000: 101). Agora é a disposição dos frutos, cobertos de açúcar caramelizado, que evoca outro elemento da natureza, a pinha. Repare-se que, não obstante o efeito visual alcançado, a redação da receita não descura a vantagem prática de se proceder a um preparado de relativa complexidade técnica: aumentar o tempo de conservação do fruto ${ }^{134}$.

Do ponto de vista da receção da cozinha francesa na mesa portuguesa requintada, o manuscrito conventual sob análise reforça a tese de que o ingresso nas comunidades religiosas femininas de jovens da alta sociedade, educadas nesse padrão cultural, terá sido determinante para o desenvolvimento no seu seio de uma cozinha requintada, em particular a doçaria ${ }^{135}$. $\mathrm{O}$ caso da receita acabada de considerar aponta nesse sentido, uma vez que num dos livros de pastelaria franceses do séc. XIX, Grand livre des pâtissiers et des confiseurs (de que consultámos a $4 .^{a}$ ed., 1884), da autoria de Urbain Dubois, deparamos precisamente com uma Croquembouche de marrons (pp. 172-173). Ainda que neste caso se dê indicações de acabamento mais refinado, o princípio das castanhas caramelizadas montadas é exatamente o mesmo. Ou seja, o manuscrito das freiras de Odivelas corresponde a uma obra de transição entre as épocas moderna e contemporânea.

De provável proveniência eclesiástica é um outro, mais breve, receituário oitocentista de doces, encontrado num arquivo particular e publicado por Paulino Mota Tavares (1995), estudioso que faz remontar a tradição culinária aí registada aos sécs. XV-XVI. O manuscrito tem por compilador um eclesiástico, o Pe. Joaquim Brito, o que levou o seu editor a intitulá-lo de

sendo possível datar a origem desse receituário, mas sendo legítimo pressupor que remontaria a uma tradição conventual transmitida por várias gerações, faz sentido o seu enquadramento na literatura culinária moderna. Sobre as problemáticas levantadas por este receituário, vd. Ornellas e Castro-Braga 2014: 447-452. As autoras oferecem um bom resumo do contexto amplo de produção culinária nos conventos, aspetos a ter em conta sempre que se analisa os seus receituários, a saber: cozinha-se tanto para prover à alimentação quotidiana, como a ocasiões festivas; além disso, as especialidades, quer doces quer salgadas, eram produzidas também para venda ou oferta a figuras que se queria agraciar.

134 Como se lê no manuscrito: "Tirão-se com 2 garfos, para sahirem inteiras, e em coalhando se pôem humas sobre as outras, em forma de pinha, para se guardarem" (sublinhado nosso).

135 Ainda que não se possam fazer generalizações, é de admitir, juntamente com Braga (2015: 30), que a cozinha conventual está mais próxima da cozinha rica das elites do que da cozinha pobre do povo. 
Livro do Padre Brito. Aí deparamos com novo "doce mimético": os biscoitos de castanhas ou beijinhos (Tavares 1995: 41). O fruto não entra na confeção da massa que vai a cozer em tabuleiros ao forno. Agora o processo de mimese passa por, retirados os biscoitos, cobri-los com uma pasta de açúcar e levá-los de novo ao forno a tostar. A semelhança do doce com as castanhas, ao que se deduz, decorreria da cor castanha que a cobertura adquiria depois de ir ao forno. O nome alternativo de beijinhos, ainda que por explicar, enquadra-se na tradição de conferir (sobretudo) à doçaria uma carga afetiva.

Considerados os manuscritos conventuais, passemos à literatura culinária portuguesa impressa, que, iniciada em $1680 \mathrm{com}$ a Arte de Cozinha de Domingos Rodrigues, não deixou de ser pontualmente integrada em alguns dos textos acabados de considerar ${ }^{136}$. No que se refere à presença de castanha no receituário impresso, é, no entanto, preciso aguardar pelo séc. XVIII para a encontrarmos. A conotação com uma mesa humilde e campestre terá, certamente, ditado a sua ausência de obras que tinham por público-alvo as mesas régias e aristocráticas do Portugal moderno. Não é de surpreender, por isso, que as parcas aparições nos livros impressos em Oitocentos e Novecentos remetam não para as tradições culinárias autóctones (do "receituário fundador" das castanhas cozidas ou assadas e dos doces de castanha), mas sejam sim a marca da influência da alta cozinha francesa na mesa das elites portuguesas.

Cozinheiro em várias cortes europeias ao longo de trinta anos, Lucas Rigaud fixa residência em Portugal e torna-se um dos cozinheiros reais de D. José e, após a morte deste, de D. Maria I. Publica em 1780 o seu livro Cozinheiro moderno ou nova arte de cozinha, cem anos após a obra pioneira de Domingos Rodrigues. Em comum com o seu antecessor, cuja fama busca suplantar, Rigaud apresenta a dívida para com o padrão cultural gastronómico dominante. Assim, a presença das castanhas dá-se apenas no recheio da ave nobre por excelência (o peru) e na preparação de molhos à base de caldos de carne ${ }^{137}$. A marca da cozinha francesa revela-se, neste caso, mesmo ao nível da própria terminologia técnica, uma vez que o autor adota as denominações ragú (do fr. "ragout") e de culi (do fr. "coulis"), para esses complementos de sopas, cremes e entradas. Como veremos no ponto que se segue da nossa análise, a permanência deste receituário refinado internacional irá prevalecer em obras subsequentes, tanto mais que o predomínio da alta cozinha francesa na literatura culinária portuguesa será uma constante até à primeira metade do séc. XX.

136 Desse trânsito dá conta Isabel Drumond Braga a propósito de algumas das advertências e conselhos constantes do receituário franciscano (Braga 2015: 48).

137 Perú recheado com salsichas, e castanhas para huma entrada, Ragú de castanhas e Culi de castanhas (Rigaud 1780: 107, 357, 363). 


\subsection{Consumo de castanha no Portugal contemporâneo: da “ALTA COZINHA” À COZINHA TRADICIONAL PORTUGUESA}

$\mathrm{Na}$ literatura culinária analisada dos sécs. XIX, XX e XXI assistimos ao consolidar de duas tendências já anunciadas anteriormente: o lugar da castanha em "receituário fundador", na sua maioria originário da cozinha simples das mesas populares; o uso da castanha na "alta cozinha" das mesas ricas.

Comecemos pelo mais antigo periódico português de temática culinária, de que foram publicados 36 folhetos, com periodicidade mensal, entre os anos de 1835 e 1837: Annona ou Mixto-curioso. Esta obra oferece a confirmação clara das duas tendências acabadas de enunciar, quer porque as únicas receitas que apresenta com castanha são os acabados de referir molhos franceses (o ragú ${ }^{138}$ e o culi $^{139}$ ), quer pela conotação do consumo de pão com farinha de castanha com a cozinha pobre, onde tem lugar só em períodos de extrema carência dos alimentos usuais. Transcrevemos as palavras integradas na rubrica "Várias qualidades de massa de pão", atendendo a que reforçam a noção de que a castanha se assumiu como ingrediente de substituição do bom cereal, no fabrico do alimento primordial que era o pão ${ }^{140}$ :

As gentes do campo, e a pobre fazem pão de centeio, de trigo misturado, com cevada, de milho, de arroz, de castanha, e outros fructos, e raizes para se remediarem em tempos famintos, e de pouco interesse.

Por sua vez, no livro de culinária editado por Paul Plantier, O cozinheiro dos cozinheiros (1870), obra emblemática do séc. XIX, o que aparece são vinte e quatro receitas em que a castanha figura como ingrediente de uma cozinha refinada ${ }^{141}$. Catorze são de pratos salgados e dez de doces. O padrão da culinária elitista sobressai dos dois tipos de preparados. Assim, em vez de uma sopa rústica (onde marcariam presença as fatias de pão e/ou as hortaliças), temos um aveludado de castanha, intitulado Sopa de purê de castanhas (p. 33). A receita confirma a comercialização da farinha de castanha, ao admitir a substituição dos frutos pelo transformado, tendo em vista simplificar as técnicas de preparo $^{142}$. Repare-se, ainda, que o autor revela sensibilidade quanto às

138 Vd. Annona, tomo III, n. ${ }^{\circ} 27$, p. 58.

139 Vd. Annona, tomo III, n. ${ }^{\circ} 29$, p. 102.

$140 \mathrm{Vd}$. Annona, tomo II, n. ${ }^{\circ} 13$, p. 7.

141 Sobral (2007: 36-37) alertou já de forma sucinta para a hegemonia da culinária internacional, especialmente a francesa, nesse best seller do séc. XIX.

$142 \mathrm{Na}$ verdade, como se pode deduzir da leitura completa da receita, o uso do fruto inteiro requeria tempo e trabalho, que o autor admite poder dispensar-se: "Escolhem-se setenta ou oitenta castanhas, tira-se-lhes a primeira e a segunda pelle, depois de terem sido levemente assadas em cinzas bastante quentes, mettem-se em seguida numa panella e deixam-se cozer n'um caldo de carne de vacca ou de aves. Quando estiverem cozidas, pisam-se aquellas que se 
valências dietéticas do prato, uma vez que assinala o seu carácter indigesto, quando termina a receita afirmando: "Esta sopa é agradável e nutriente, mas muito pesada". Continuamos a contar com a presença da castanha numa receita espanhola, que já atrás veio registada por frei Manuel de Santa Teresa, a Olha podrida (p. 37). Na linha da também já registada utilização da castanha em recheio de assados, vemos ampliar-se o universo das aves, que deixa de estar circunscrito ao peru ${ }^{143}$, para incluir também o ganso ${ }^{144}$. As castanhas são também elevadas à categoria de guarnição de aves ${ }^{145}$. Ou seja, a mesa da elite dos sécs. XVIII e XIX, retratada nos livros de culinária, combina as castanhas sobretudo com aves, ignorando o porco, sendo esta última a associação mais frequente em tempos medievais ${ }^{146}$.

Também no caso concreto da preparação de aves assadas no espeto, servidas acompanhadas de castanhas ou integradas no seu recheio, os paralelos com o receituário francês contemporâneo do livro de Plantier são fáceis de detetar. Vejam-se as receitas de Canard et caneton à la broche (p. 270) e Dinde à la broche et farci (pp. 287-288), incluídas no maior best seller francês do séc. XIX, o livro de Louis-Eustache Audot La cuisinière de la campagne et de la ville ou la nouvelle cuisine économique (Paris 1900, 78. ${ }^{\mathrm{a}} \mathrm{ed}$. ).

$\mathrm{O}$ fruto pode igualmente servir de complemento a qualquer tipo de carne, cozida apenas para obter um caldo substancial, conforme verificamos pela inclusão, na rubrica "Modos diversos de arranjar carne que serviu para fazer caldo", de uma receita de Picado de carne com castanhas (p. 114). Também pode oferecer-se como alternativa à batata, no preparo da receita de Picado de carneiro assado (pp. 169-170). Finalmente, na rubrica dos salgados, há ainda que ter em conta o Purê de castanhas (p. 440), que também constituiria uma guarnição ou entremeios ${ }^{147}$. Esta literatura culinária era de matriz internacional e não exclusivamente francesa, o que se confirma pela alusão a outro dos modelos de cozinha europeus mais marcantes à época, a culinária italiana. Neste caso, a alusão aparece em Castanhas guisadas à genoveza (p. 95).

acharem esmagadas para fazerem um bom purê, que se passará pela peneira, molhando-o com o mesmo caldo. As castanhas que estiverem inteiras servem para guarnecer a sopa. Para simplificar a preparação d'esta sopa, pôde empregar-se a farinha de castanha" (Plantier 1870: 33).

143 Vd. Perú á chipolata, p. 253; Perú recheiado com castanhas, p. 269.

144 Vd. Ganso estufado, p. 258; Ganso com castanhas, no espeto, pp. 270-271.

145 Vd. Ganso em salmis (p. 261); Frango com castanhas (p. 266); Pato recheiado (p. 268, caso em que as castanhas figuram não no recheio, mas como acompanhamento) e Ancas de perdigoto (pp. 285-286).

146 Como vimos anteriormente no ponto 1.2.

147 "Entremeios", como esclarecem Pereira-Pericão (2015: 225), é a tradução para português do termo francês "entremets", usado para designar, nos sécs. XVIII e XIX, os pratos servidos entre o assado e a sobremesa. Tratava-se de pratos mais leves, como legumes, cremes e pastelinhos. 
Também os doces feitos com castanhas assentam em elaboradas, e no geral demoradas, técnicas de preparação. É possível, no entanto, perceber que três deles retomam ou aparentam-se a receitas presentes em textos anteriormente considerados. É o caso da Potagem de castanhas (p. 49), prato que, por comparação com as castanhas em potagem do manuscrito franciscano do séc. XVIII, já se despojou por completo dos elementos salgados, atingindo agora o estatuto pleno de prato doce. Mantém-se, no entanto, a recomendação de aromatizar o creme com canela "ou qualquer outra essência agradável". Reaparecem igualmente as castanhas cobertas (p. 578), mas, quando comparada esta receita com a do referido manuscrito conventual, é flagrante o grau de complexificação que se atingiu. Os frutos passam a ser depositados em cinco dias sucessivos em calda de açúcar, que vai sendo refervida, para, no termo, serem cobertos de açúcar, que, por formar uma capa dura, não serve para conservar. Os processos que permitem a conservação são outros, entre eles retoma-se a técnica da caramelização do fruto, o que dá à receita o nome de castanhas com caramelo (p. 511). Embora neste caso se não considere a sua composição em pinha (como sucedera atrás na receita castanhas em doce do manuscrito das freiras de Odivelas), a verdade é que há pontos de contacto entre essa técnica e a das castanhas cobertas incluídas na rubrica "Pastelarias altas" do livro de Plantier. Estas, depois de cobertas de caramelo, são dispostas numa forma, encostadas umas às outras, sendo o resultado final uma espécie de "torrão" de castanhas (p. 542).

São ainda contemplados modos novos de confecionar as castanhas em doces finos. As alusões a utensílios próprios para preparar ou servir as iguarias atestam o próprio requinte da culinária. Esse é o caso da compota de castanhas (pp. 510-511) - cujos frutos, depois de cozidos em calda de açúcar, iam à mesa em compoteiras - e do pastellão de castanhas (pp. 483-484), que ia cozer ao forno em torteira untada de manteiga. Outros dois preparados completam a lista de doces de castanha d'O cozinheiro dos cozinheiros: um seco (os fofos de castanha, p. 489) e outro de colher (o creme de castanhas, p. 495). Este último é mais um bom exemplo do frequente recurso à multi-cocção da alta cozinha, uma vez que se prepara um creme ao lume com açúcar, natas, manteiga, ovos e farinha de castanha, para depois se levar ao forno a tostar, sendo que, caso o desejado efeito não se atinja, se recomenda queimar a superfície polvilhada com açúcar com uma pá em brasa. Neste caso, também a substituição (implícita) do fruto pela sua farinha é indiciadora do estatuto social mais elevado dos putativos consumidores deste "creme de castanhas queimado". No meio de toda esta cozinha requintada há, todavia, também lugar para um preparado simples, o das castanhas com açúcar (p. 511). Cozidas sem casca, para facilitar a extração da pele, as castanhas servem-se quentes, envolvidas em açúcar. $O$ toque de requinte, a nosso ver, revela-se na adição, à água de cozedura, de uma aromática erva-doce bem diversa da vulgar e 
apreciada pelo povo, o anis-verde. Note-se, porém, que a disponibilidade (sazonal) do fruto marcava presença à mesa de todas as camadas sociais, como parece depreender-se da sugestão, na receita Soprosinhos (p. 551), de se usar castanhas cozidas e esmagadas em alternativa à fécula de batata.

Em suma, a cozinha tradicional, de origem popular, não tem lugar nos livros de culinária publicados até ao final do séc. XIX. Essa é uma realidade que o setor editorial português reconhece, a ponto de, no início do séc. XX, mais propriamente em 1901, ser dado à estampa um volume que busca responder a semelhante lacuna. A obra em questão dava-se pelo extenso título de $O$ cozinheiro popular dos pobres e ricos ou o moderno tesouro do cozinheiro. $\mathrm{O}$ subtítulo $O$ cozinheiro dos pobres corresponde à I parte, ficando no prólogo anunciada a intenção de se seguir a II parte, consagrada ao Cosinheiro dos ricos, que conteria os "novos progressos da Culinaria Portugueza, Franceza, Ingleza e Allemã” (p. 6). Na medida em que constituem um documento de época sobre a cisão clara entre uma culinária internacional, presente à mesa dos mais abonados, e uma culinária tradicional portuguesa, que assistiria à mesa das gentes de parcos ou modestos recursos, transcrevemos as palavras de abertura dessa "advertencia aos cosinheiros, cosinheiras e donas de casa" (p. 5):

Desde 1850 a esta parte, se tem publicado centenas de tratados de cosinha, mas em que todos eles prodomina a Culinaria estrangeira; isto é, a composição das formulas são todas tiradas da cosinha Franceza, Ingleza e Allemã, sendo esta de paladar exquisito, difficil a sua manipulação e carissimos os alimentos que as compõe - podendo servir só para a cosinha dos ricos - motivo que me levou a pedir á Ex.ma Snr. ${ }^{a}$ D. Michaella, para ella se encarregar de coordenar um Cosinheiro dos Pobres servindo-se de formulas simples, saudaveis e economicas e de facil manipulação, para este cozinheiro ser utilisado na cosinha dos pobres e remediados; $[. .$.$] .$

Este trecho tem ainda o particular interesse de identificar aqueles que são os marcadores distintivos das duas cozinhas coexistentes e contrastantes, contempladas no panorama editorial português: a "cozinha dos ricos" e a "cozinha dos pobres", ou, para usar terminologia cara ao universo dos estudos antropológicos, a "alta cozinha" e a "baixa cozinha” ${ }^{148}$. É, por conseguinte,

148 Sobre a aplicação desta conceção aplicada à cozinha portuguesa, vd. o estudo de Sobral (2014a), justamente intitulado "The high and the low in the making of a Portuguese national cuisine in the nineteenth and twentieth centuries". O autor adota a proposta teorizada pelo antropólogo Jack Goody, no seu livro de referência Cooking, Cuisine and Class: a Study in Comparative Sociology (Cambridge University Press, 1982). Ou seja, enquanto a noção de "alta cozinha", reservada às elites, se caracteriza por maiores quantidade e diversidade de ingredientes empregues, pela presença de alimentos exóticos e complexidade das técnicas de preparo, na "baixa cozinha", praticada pelo comum da população, ao invés, a paleta de ingredientes é menor, 
natural que na obra coordenada por Michaella de Sá Carneiro, graças ao pendor economicista das receitas, não surja nenhuma das receitas requintadas do Cosinheiro dos cozinheiros de Plantier, mas se retome um dos preparados "fundacionais" do uso culinário da castanha, o caldo ou sopa ${ }^{149}$. Aqui encontramos o primeiro registo literário de uma receita de sopa de castanhas piladas (p. 9), preparado que, como veremos em obras posteriores, verá reconhecido o seu estatuto de prato regional e nacional português, de origem popular, como se percebe.

$\mathrm{Na}$ verdade, fruto das ideologias nacionalistas que perpassam os governos e parte da sociedade portuguesa (sobretudo as elites políticas e literárias) durante a Monarquia Constitucional, a República e o Estado Novo, surge um movimento de apologia da portugalidade e concomitante distanciamento da hegemonia cultural estrangeira, em particular do padrão de referência que era a cultura francesa. Não obstante, os livros de culinária, publicados em Portugal em maior número a partir da primeira metade do séc. XX, continuam a ser sobretudo o reflexo desse domínio cultural de uma cozinha internacional. Marcam igualmente lugar no panorama editorial nacional obras especialmente apostadas na defesa da arte culinária nacional ${ }^{150}$. Será nestas que terão registo as receitas de castanha de proveniência ou inspiração na "cozinha dos pobres", a cozinha popular.

A nossa seleção de fontes pretendeu dar conta da diversidade de perfis editoriais das obras publicadas na Época Contemporânea. Assim, considerámos dois livros em que predominam os modelos culinários estrangeiros, cujo sucesso de vendas e sucessivas reedições atestam a influência que tiveram na educação culinária de sucessivas gerações de famílias portuguesas de classe média e alta: Doces e cozinhados (1925) ${ }^{151}$ e O Livro de Pantagruel (1945) ${ }^{152}$.

pois está condicionada às disponibilidades locais e sazonais de produtos, bem como ao baixo poder económico dos consumidores.

149 O que nos demonstram as receitas nomeadas de "caldo" e de "sopa" é que, no segundo caso, comparece sempre na composição do prato pão e/ou hortaliça ou massa. O elemento emblemático é a adição de algum componente que "engrosse" o caldo, sendo que na origem, pelo papel preponderante que tinha na mesa das populações ocidentais, coube exclusivamente ao pão desempenhar essa função. Assim, quando Bluteau regista a entrada Sôpa no seu dicionário, escreve: "Fazem-se com bocados, ou fatias de paõ" (vol. 7, p. 725).

150 Sobre a dívida das obras de finais do séc. XIX e inícios do XX para com modelos culinários importados e a concomitante emergência da dita culinária portuguesa, vd. Sobral 2007; 2014a; 2014b.

151 A edição consultada foi a $25 .^{\mathrm{a}}$ (1977).

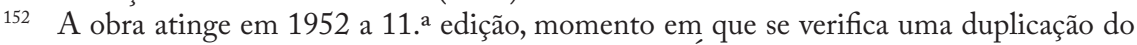
número inicial de receitas, que aumenta de 1500 para 3000. É também nessa altura que se assiste à introdução, num universo exclusivo de cozinha burguesa, de receitas destinadas a extratos sociais menos favorecidos. Introduzem-se, então, rubricas culinárias que denunciam preocupações economicistas e orientadas para um público económica e socialmente mais diversificado. Dessas reorientações dão conta o aparecimento das seguintes novas quatro rubricas: cozidos, bacalhau, 
Para rastrear a presença da cozinha popular, selecionámos obras de marcado pendor nacionalista. Do grupo da literatura culinária nacional, analisámos as obras fundadoras, anteriores à instauração da democracia (Cosinha Portugueza, 1902; Culinária Portuguesa, 1936), e outras duas do último quartel do séc. XX em diante. Efetivamente a bandeira do nacionalismo culinário não é recolhida com a instauração do regime democrático. Apenas se reconfigura. Como bem sublinhou José Manuel Sobral (2007), os ideais socialistas próprios da nova ideologia política, apostados em dar protagonismo ao povo, passavam pela valorização da cultura e tradições populares, entre elas a culinária. Assim, do vasto leque de obras então publicadas, cingimo-nos à recolha de receituário tradicional que mais impacto teve no pós-25 de abril (a Cozinha tradicional portuguesa, de Maria de Lourdes Modesto, 1981) e à magna obra de Maria Odette Cortes Valente, publicada já no séc. XXI (Tesouro da Cozinha Regional Portuguesa, 2008). O universo de obras contempladas no nosso estudo completa-se com uma publicação periódica, a Banquete - Revista Portuguesa de Culinária (1960-1974) ${ }^{153}$, a qual, sobretudo por via das suas rubricas "Petiscos da nossa terra" e "Há convidados", se revela um fértil terreno para apurar a presença da castanha, tanto na "baixa" como na "alta" cozinhas.

Primeiro tenhamos em linha de conta o receituário da castanha incluído nos livros de culinária portugueses de marcado pendor internacional. No caso das duas obras que consideraremos de seguida, a ponderação dos dados biográficos das autoras auxilia numa leitura sociológica das obras, ajudando, em concreto, a explicar a forte presença da "alta cozinha" nessas coletâneas de receitas. Por detrás do pseudónimo Isalita escondem-se as identidades das duas autoras do livro Doces e Cosinhados: Receitas Escolbidas (Lisboa: Livraria Bertrand, 1925154). Na verdade o nome formara-se da junção das duas sílabas

enchidos e alimentação para crianças. Também a aproximação à culinária nacional faz parte das principais renovações desta edição, com uma presença clara de cozinha portuguesa, muito em especial no setor da doçaria. A obra volta a sofrer significativo incremento de receituário (atingindo as 5000 receitas), por ocasião da 49. a ed., revista e aumentada pela atual responsável pelo livro, Maria Manuel Limpo Caetano, filha da autora, Bertha Rosa-Limpo. A edição que consultámos foi a 18. ${ }^{a}$ (1955). Trata-se do livro de culinária mais vendido em Portugal, tendo atingido a $76 .^{\mathrm{a}}$ ed. em 2012.

${ }_{153}$ A publicação é suspensa, na sequência da nacionalização por que passou, no pós-25 de abril, a empresa proprietária da revista, a Gazcidla. Ou seja, a série contínua tem o n ${ }^{\circ}$. 174 como derradeiro (outubro/novembro de 1974). Em dezembro do ano seguinte edita-se um único número, o 175, que é o índice de todas as receitas saídas ao longo dos seus 14 anos de publicação ininterrupta. A revista terá um fugaz renascimento, em 1977, com a publicação de um só número, o 177 (Natal).

${ }^{154}$ À falta da $1 .^{\text {a }}$ edição, optámos por consultar outras duas edições, a 3. ${ }^{\text {a }}$ (1937? ) e a $25 .^{\text {a }}$ (1977). Há uma série de alterações a nível de redação (como a nomenclatura e apresentação das receitas por ordem alfabética) e de conteúdo (com novas receitas), que não iremos aqui discutir na totalidade. Vamos apenas explorar as modificações verificadas entre o receituário da castanha publicado numa e noutra edições. 
iniciais do nome próprio da portuguesa Isabe ${ }^{155}$ e das duas sílabas finais do diminutivo da espanhola Angelita ${ }^{156}$. Ambas pertencentes à elite lisboeta, foram formadas nos gostos refinados da época, berço cultural que vemos plasmado na escolha do receituário que compõe a obra editada a meias ${ }^{157}$, a qual revela, por isso mesmo, preparados anteriormente publicados em livros onde predominava a "cozinha rica", de inspiração estrangeira.

Esse é o caso dos três pratos salgados de castanhas publicados por Isalita, presentes em ambas as edições confrontadas: Peru recheado com castanhas ${ }^{158}$, Castanhas estufadas ${ }^{159}$ e Puré de castanhas ${ }^{160}$. A pegada literária do primeiro, conforme vimos, conseguimos fazê-la recuar ao livro de 1780 de Lucas Rigaud, ainda que, diferentemente desse livro e do de Plantier (de final do XIX), nesta receita se proponha apenas rechear o papo da ave e não toda a cavidade abdominal, como sucedia nas receitas anteriores. Já para as castanhas estufadas e em puré, ainda que com ligeiríssimas variantes, a proximidade ao receituário de Plantier é por demais evidente. No caso das primeiras, é relevante notar que a supressão, no texto de Isalita, da expressão "à genovesa" denuncia um fenómeno de "desterritorialização", que reencontraremos em outras receitas. Ou seja, determinados preparados, objeto de transmissões sucessivas, a que muitas vezes assistem processos (mais ou menos significativos) de reformulação, perdem a ligação a uma determinada origem (cultural ou geográfica). Esta perda de tipicidade significa a vulgarização do prato, que perde uma identidade específica e se torna uma espécie de "universal culinário" (pelo menos na perspetiva do autor/compilador da obra, responsável pela fixação dos títulos das receitas $\left.{ }^{161}\right)$.

Considerando o receituário de doces com castanhas na sua totalidade, verificamos que o predomínio é dos doces finos, elaborados segundo técnicas complexas, cuja origem francesa de alguns se denuncia nos nomes genéricos por que são conhecidos - soufflé (Soufflé de castanhas ${ }^{162}$ ) e Flan de castanhas ${ }^{163}$.

155 De seu nome completo Maria Isabel de Sousa Campos Henriques.

156 Angela Carvajal y Pinto Leite Telles da Silva.

157 Segundo depoimento de Maria Augusta Velhuco, empregada de servir da casa de Maria Isabel de Sousa Rego Campos Henriques, em entrevista à revista Visão Gourmet, a sociedade entre as duas amigas foi sobretudo financeira (para pagamento dos custos das placas de impressão do livro à editora Bertrand). Sobre este assunto, leia-se Belo Luís (2012).

158 Cf. p. 123 (3. ${ }^{\mathrm{a}}$ ed.) e p. 131 (25..$^{\mathrm{a}}$ ed.).

159 Cf. p. 183 (3. ${ }^{\mathrm{a}}$ ed.) e p. 188 (25..$^{\mathrm{a}}$ ed.).

160 Cf. p. 183 (3. ${ }^{\mathrm{a}}$ ed. $)$ e p. 188 (25. ${ }^{\mathrm{a}}$ ed. $)$.

161 Como bem alertou Bower (1997: 31), os títulos desempenham um papel central na hermenêutica narrativa dos livros de culinária coletivos. Porque constituem formas de auto-representação, devem ser "lidos" sempre nessa perspetiva, ou seja, como a orientação de "leitura" do autor para o público.

162 Cf. p. 236 (3. ${ }^{\mathrm{a}}$ ed.) e p. 223 (25. ${ }^{\mathrm{a}}$ ed.).

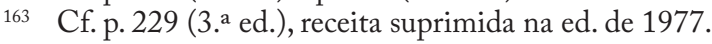


Aliás, a origem/inspiração francesa torna-se mais evidente, se se recorrer ao uso de um topónimo. Esse é o caso evidenciado, quando comparamos o receituário da edição mais antiga com o publicado 40 anos mais tarde. Provavelmente devido à banalização e consequente apropriação do termo técnico flan para a culinária portuguesa, em 1977 já o público leitor do livro de Isalita perdera a consciência de que um Flan de castanhas provinha de França. Terá, em nosso entender, sido essa a causa para se recuperar a aura chic do doce, substituindo o referido nome Flan de castanhas por Doce de castanhas de $\mathrm{Nice}^{164}$. Outras vezes, a filiação de uma receita na culinária francesa confirma-se por outra via, pela presença de receitas idênticas em livros dessa proveniência. É o caso do soufflé, de que o mais editado livro de cozinha francesa do séc. XIX - La cuisinière de la campagne et de la ville ou la nouvelle cuisine économique de Louis-Eustache Audot - publica um Soufflé à la pomme de terre, au café, chocolate, etc. (p. 412), onde se indica a farinha de castanha como uma das alternativas à fécula de batata.

Outras vezes é sobretudo da complexidade técnica exigida e da carestia dos ingredientes usados nas receitas que se depreende pertencerem à "alta cozinha”. Os exemplos mais expressivos desta realidade são duas receitas acrescentadas na $25 .^{\text {a }}$ ed.: um bolo frio de castanhas ${ }^{165}$, coberto de chocolate (Maravilha de castanhas, p. 234), e um bolo de castanhas coberto de natas (Nevado de castanhas, p. 237). Aliás, o luxo de muitos destes pratos de cozinha requintada traduz-se no recurso insistente ao enfeitar dos doces, que, além das já mencionadas coberturas, também podem ser servidos com cremes, como é o caso do supra referido Doce de castanhas de Nice ${ }^{166}$, acompanhado de um creme aromatizado de baunilha. Mais, essas finalizações dos doces têm um fim estético confesso, concordante com o desígnio subjacente a estas mesas ricas de impressionar pelo aparato visual. Para essa realidade nos remetem as últimas palavras da receita do Nevado de castanhas: "Depois de desenformado, cobre-se todo com natas. Fica mais bonito meter as natas num saco de pano com funil e guarnecer o bolo".

Mas o livro de Isalita contempla duas receitas que, embora com os seus toques de requinte, entroncam na longínqua e progressivamente vulgarizada técnica de conservação da fruta pelo doce. Julgamos que o peso da tradição

164 Cf. 25. a ed. (pp. 229-230).

165 A massa batida não vai a cozer ao forno, mas apenas ao frigorífico, donde o preparado é retirado e coberto com chocolate, antes de servir. Seria uma espécie de semi-frio. Repare-se que as castanhas eram cozidas ao lume em leite, aromatizado de baunilha, ingrediente denunciador do requinte do prato, pois a vagem, sendo de uma planta não autóctone (nativa do México), e seus derivados eram uma das especiarias mais caras.

166 Este, verdadeiramente é um pudim. Evitámos, no entanto, usar o nome "pudim" (este de importação inglesa, da palavra pouding), pois a receita não foi incluída na subrubrica do livro "Pudins e souffés". Contudo, o processo de cozedura em banho-maria levar-nos-ia a categorizá-lo como tal. 
terá determinado a manutenção das receitas nas duas edições consultadas. Assim, regista-se, sob o título Doce de castanhas inteiras ${ }^{167}$, uma variante de castanhas cobertas de açúcar, bastante próxima da de Plantier. Na linha das conhecidas marmelada, perada e pessegada, vemos surgir uma Castanhada ${ }^{168}$. A ausência deste aproveitamento do fruto do castanheiro nas obras anteriormente consideradas deverá indicar que, nos contextos de produção de tais receituários, a disponibilidade do fruto era relativamente modesta e/ou que se dava preferência ao seu consumo sob outras formas.

Por que razão no livro de cozinha Doces e cozinhados surge uma receita destas e por que é que, por comparação com os demais receituários da época (décadas de 20 e 30) e anteriores, este é dos livros que mais receitas apresenta com o ingrediente castanha são questões a que não saberemos dar uma resposta segura. No entanto, alguns elementos biográficos fornecidos à revista Visão Gourmet por Maria Augusta Velhuco, criada de servir de Maria Isabel de Sousa Rego Campos Henriques, ajudam a vislumbrar determinadas causas para tais escolhas. Como bem alertou Annie Bower (1997: 30-31), a escrita feminina de livros de culinária tem um carácter autográfico, mais do que biográfico, pois contém um discurso parcelar e fragmentado da vida do "eu" autoral. Em suma, as receitas publicadas emergiram do universo familiar e relacional da autora Isabel, ideia confirmada pelo testemunho de Maria Augusta, que, à pergunta da jornalista "As receitas do livro eram testadas lá em casa?", responde "Tudo o que ia para o livro era experimentado" (Belo Luís 2012: 32). Mais, as fontes inspiradoras para a seleção das receitas foram, ainda nas palavras dessa testemunha vivencial do ambiente de produção do livro, as receitas herdadas da mãe, algumas descobertas pela autora fora de casa e que depois reproduziu, outras aprendidas com cozinheiras da sua casa e mesmo criações pessoais.

Logo muito do que contém o livro Doces e cozinhados corresponde à “cozinha dos afetos” de Maria Isabel Henriques ${ }^{169}$. Parte dessas memórias gustativas evocam, seguramente, os ingredientes comuns à mesa da família. Desse universo gastronómico identitário é possível que tivesse feito parte a castanha, uma vez que, ainda com base no testemunho da sua empregada, o ramo Sousa Rego da família de Maria Isabel era natural de Moledo e o ramo Campos Henriques de Guimarães. A existência de duas propriedades de família na zona de Entre Douro e Minho, uma das regiões de Portugal

167 Cf. p. 222 (3. ${ }^{\text {a }}$ ed.) e p. 229 (25. a ed.).

168 Cf. p. 225 (3. ${ }^{\mathrm{a}}$ ed.) e p. $226\left(25 .^{\mathrm{a}}\right.$ ed. $)$.

169 Designamos por "cozinha dos afetos" aquela que se constrói no seio da família e do círculo de amigos dos sujeitos. Corresponde ao que Hubert (2000: 10), servindo-se de uma expressão importada da linguagem dos antigos escravos negros americanos ("soul food"), apelidou de "nourriture de l'âme". 
com mais tradição no plantio e consumo da castanha, constitui, a nosso ver, um dado biográfico que ajuda a interpretar a expressiva presença de pratos de castanha no livro sob análise.

Como nos é dado perceber por Maria Augusta Velhuco, a sua patroa era dada a criações culinárias. A essa "cozinha de autora" não escapou a castanha, bem como outros ingredientes e iguarias. No entanto, importa notar que a emergência do "eu" autoral, feminino, não aparece na edição mais antiga analisada por nós, mas apenas na da década de 70. Este aspeto é muito relevante em termos de informação sociológica e de evolução das mentalidades, pois atesta a evolução progressiva que na sociedade portuguesa se fez no sentido da emancipação da mulher. Ou seja, se nas décadas de 20 e 30, ainda era a moral conservadora que impunha a discrição e o recato às mulheres no domínio público, mais tarde (nas décadas do pós-II Guerra Mundial e mais intensamente sob os ventos da democracia), elas acabam por ir progressivamente conquistando o direito a projetar-se na esfera pública. Esse progresso traduz-se, ao nível da relação das mulheres-editoras com os seus livros, no aparecimento da "cozinha de autora”. Esta transformação é tão evidente que, ao invés das edições mais antigas, das quais estava ausente o nome Isalita dos títulos das receitas, na ed. de 1977 essa presença torna-se verdadeiramente marcante, com a publicação de oito receitas apelidadas de "Isalita" ${ }^{170}$.

Importa-nos considerar as Castanhas Isalita (p. 287), preparado em que se atinge uma espécie de paroxismo do requinte culinário. Falamos em atingir o patamar máximo da "cozinha mimética", o qual consiste em descascar e desfazer as castanhas para com elas fazer uma pasta doce de castanha da qual se moldam novas castanhas. $\mathrm{O}$ produto final são castanhas revestidas de uma imitação da casca natural, feita com chocolate derretido. Em suma, o paroxismo culinário reside em transformar um fruto natural num fruto artificial, sem se abdicar do uso daquele na confeção deste!

Publicado vinte anos depois da primeira edição dos Doces e cozinhados, o Livro de Pantagruel (1945) consiste numa compilação de receitas levada a cabo por Bertha Rosa Limpo, senhora e dona de casa de boas famílias, com uma carreira de artista de canto e de piano $^{171}$. Na obra, a autora reúne receitas de várias proveniências, como a própria dá a entender nas palavras introdutórias à obra. Além das amigas, a quem reconhece o título de "cozinheiras amadoras" na primeira página do livro, denominada "página de honra”

170 A saber: Ovos Isalita (p. 45), Filetes de linguado Isalita (p. 65), Peru Isalita (p. 71), Crepes Isalita com espargos e Crepes Isalita com fiambre (p. 164), Praliné Isalita (p. 239), Supremo de ananás Isalita (242), Torta Isalita (p. 244) e Bolo-rei Isalita (266).

171 Sobre a importância da obra no contexto do panorama da literatura culinária feminina portuguesa, vd.: Braga 2008: 131; Braga-Ornellas e Castro 2013. Para uma biografia de Bertha Rosa Limpo, vd. Moreau 2005. 
(espécie de tabula gratulatoria), recorreu igualmente aos conhecimentos adquiridos em restaurantes que foi frequentando nas viagens que fez pela Europa, sendo que o seu elevado nível social a colocou em contacto com a alta cozinha estrangeira então mais prestigiada, a francesa e a italiana. Claro que parte importante do seu receituário constituía um verdadeiro património culinário familiar, composto, como a própria escreve, pelas "boas receitas que existiam na família” (p. XI) 172. A todas estas "inspirações”, há que juntar o que modernamente se designa de "cozinha de autor(a)" ${ }^{173}$, vertente que orgulhosamente Bertha Rosa Limpo anuncia nos seguintes termos (p. IX): "Assim, por aí fora, fui enchendo cadernos, cadernos ordenados, com os seus competentes índices, de receitas experimentadas, corrigidas, aperfeiçoadas e também algumas... inventadas".

Considerando o ambiente sociocultural da autora, não é de estranhar, na sua obra, o quase total domínio da cozinha internacional sobre a portuguesa. Essa linha editorial é tanto mais evidente quando se considera um ingrediente regional e da cozinha tradicional, como a castanha, uma vez que o que B. Rosa Limpo publica são apenas receitas da "alta cozinha", todas as quatro exibindo no respetivo título uma expressão adjetival de topografia estrangeira (“à francesa” ou "à italiana”). Estas "importações” gastronómicas poderão ter sido recolhidas em livros de culinária internacional, que seguramente conheceria e usaria, ou então corresponder a "ofertas" que, no decurso das suas digressões pelo estrangeiro enquanto cantora lírica e por ocasião das estadias em vários hotéis, lhe foram feitas por chefes cozinheiros desses estabelecimentos.

É, porém, na descrição técnica do receituário que comprovamos que essas receitas correspondem a preparados sofisticados: na categoria dos salgados, temos os recheios de aves ${ }^{174}$, e no dos doces, os pudins ${ }^{175}$. Relativamente aos dois preparados de recheio, interessa observar o cuidado da autora em indicar, entre parênteses e a fechar cada receita, as espécies de aves a que se destinam. Embora ambos possam ser usados para rechear perus, a primeira ave a que vem ligado esse recheio na literatura culinária anterior, o recheio "à francesa" também se destina a patos e galinhas, ao passo que a versão italiana podia ser usada em gansos, cumulativamente com o peru. Esta generalização do recheio com castanhas a diversas aves de capoeira já surgira anteriormente, como oportunamente assinalámos. Quanto aos pudins, o luxo culinário evidencia-se

172 Dessa "cozinha dos afetos" familiares, refiram-se, a título de exemplo: Argolas da prima Maria (p. 540), Bolo da prima Guiomar (p. 661), Maçãs da Tia Firmina (p. 847) e Arroz doce à moda da minha Mãe (p. 744).

173 Matriz evidente no título da receita Bolo de chocolate à minha moda (p. 662).

174 Vd. r. 301: Recheio de castan has para aves à francesa; $r$. 302: Recheio de castanhas à italiana.

175 Vd. r. 4035: Pudim de castanhas à francesa; r. 4036: Pudim de castanhas à italiana. 
na prática da cobertura com cremes: ou com chantilly (ou em alternativa o creme Saint-Honoré, sendo que em ambos os casos a própria terminologia revela a origem francesa das receitas), caso do Pudim de castanhas à francesa; ou com merengue, como sucede com o Pudim de castanhas à italiana. A presença destes "acabamentos", já o percebemos por várias receitas do livro de Isalita, era um emblema da "cozinha rica" estrangeira.

Passemos, de seguida, a centrar a nossa atenção na literatura em que é possível rastrear a presença de um receituário tradicional da castanha, de origem popular e apresentado como património gastronómico identitário nacional. É chegado o momento de recuperar a noção atrás exposta de "receituário fundador", lembrando que nessa categoria se inclui a "sopa", o preparado que, em textos teorizadores escritos por autores que veiculavam a ideologia nacionalista do Estado Novo, é considerado emblemático da identidade alimentar portuguesa. Papel decisivo, nesses primórdios da afirmação literária da gastronomia nacional, tiveram duas figuras de proa da política e cultura gastronómica portuguesa, António Maria de Oliveira Bello e Albino Forjaz Sampaio ${ }^{176}$.

Vogal da Comissão de Propaganda de Turismo no Estrangeiro e 1. ${ }^{\circ}$ presidente da Sociedade Portuguesa de Gastronomia (SPG), Oliveira Bello escreve a segunda obra portuguesa a exibir no título a bandeira do nacionalismo culinário: Culinária Portuguesa (publicada em 1936, no ano imediato ao seu falecimento). Já Forjaz Sampaio foi jornalista, bibliógrafo e autor de diversas obras, de que ao tema do nosso estudo interessa uma em particular: Volúpia, a Nona Arte: a Gastronomia (1939). As obras atestam bem o perfil diverso dos dois autores: prático, o primeiro (que edita um livro de receitas, finalizado por duas secções especializadas, uma em queijos e outra em vinhos); teórico, o segundo (cuja obra é antes um "tratado de gastronomia"177). No entanto, em comum tinham o desígnio de promover a cozinha portuguesa, entendida como alavanca do turismo emergente e da dinamização económica e do progresso num setor que ia crescendo um pouco por toda a Europa ${ }^{178}$, interesse que certamente explica que tenham estado ambos ligados à fundação, em 1933, da já mencionada Sociedade Portuguesa de Gastronomia.

176 Sobre a biografia das duas figuras, vd. Grande Enciclopédia Portuguesa e Brasileira, sub verba "Forjaz de Sampaio (Albino)" e "Bello (António Maria de Oliveira)".

177 Como vem apelidado no Diário de Lisboa (n. ${ }^{\circ}$ 9439, p. 6), em notícia publicada por ocasião da sua morte, a 11 de março de 1949.

178 Conforme levantamento realizado por Ana Maria Ramalho Proserpio, apresentado em estudo elaborado para a avaliação da disciplina "Identidades e Patrimónios Alimentares" do curso de doutoramento em Patrimónios Alimentares: Culturas e Identidades da FLUC, a referência de que o objetivo da associação residia em "elevar a culinária e o turismo da nossa terra" constava da carta-circular enviada, a 20 de outubro de 1932 (Pasta 88 do Arquivo da $\mathrm{SPG})$, aos futuros sócios da SPG. 
No prefácio do livro de culinária nacional de Olleboma ${ }^{179}$, texto inicialmente composto como conferência ${ }^{180}$, deparamos com a confirmação de se reconhecer à sopa em geral o estatuto de preparado identitário da cozinha portuguesa:

Vejamos agora quais as características da cultura culinária portuguesa. Para os portugueses a refeição sem um caldo ou sopa para começar não é completa: faltar-lhe-ia de entrada qualquer coisa indispensável (Bello 1936: 8).

Poucos anos mais tarde, Forjaz Sampaio (1939: 14) desenvolve a proposta contida nesta caracterização da identidade culinária nacional, elevando a sopa de "entrada" (indispensável!) a "refeição" (completa):

Nisto de sopas, em Portugal há para todos os gostos e tudo pratos so-
berbos. Não há o consommé leve, aguado, límpido ou turvo, mas no fundo
água tépida. Não há. Há a sopa forte, nutritiva, substancial. Em alguns
povos, a sopa é a preparação para o jantar. Em Portugal, a sopa é já
jantar. Entre as melhores pode contar-se a canja de galinha com arroz e
miúdos da ave, com uma fêvera de presunto e um ovo desfeito, queren-
do. Também é óptima a sopa de grelos, a de coentros e é de uso a sopa
de castanha pilada.

Que a valência dietética do preparado primordial que é a sopa, na típica alimentação portuguesa, constitui argumento para o seu elogio depreende-se do uso dos adjetivos que a qualificam de "forte, nutritiva, substancial". Recorde-se que este discurso de que a alimentação tradicional do país é garante de saúde soava particularmente bem aos ouvidos de uma população que vivia as restrições económicas e de abastecimentos decorrentes de uma Guerra Mundial em que não combatia, mas que lhe empobrecia os mercados. Portanto, o encómio de uma alimentação nacional nutritiva revela, sob um prisma de leitura política, o alinhamento do discurso teórico culinário com as diretrizes propagandísticas do Estado Novo de vigor inquebrantável do Homem Português, sadio devido às suas tradições rurais.

É verdade que o primeiro (logo, o mais significativo) exemplo que dá desse cardápio nacional de sopas, a canja de galinha, coincide com a que abre a lista de quatro sopas portuguesas "fundamentais e mais características" de Bello (1936: 8). Já o destaque dado à sopa de castanha pilada decorrerá, a nosso ver, da circunstância concreta para a qual foi redigido esse texto, originalmente publicado em francês para integrar o folheto Le Portugal Gastronomique

179 Pseudónimo formado a partir das iniciais do autor, lidas ao contrário: OLLEB de Bello, O de Oliveira, M de Maria e A de António.

180 Escrita para ser proferida pelo autor no I Congresso Nacional de Turismo, pelo que a intitulara "A culinária portuguesa e o turismo", o que não veio a suceder, devido à sua morte. 
(1937) ${ }^{181}$. O gastrónomo, sensível à previsível maior estranheza que este prato causaria entre o público leitor do seu panegírico ao "receituário fundador" da culinária portuguesa (os visitantes estrangeiros da exposição de Paris e potenciais turistas de Portugal), parece sentir necessidade de justificar essa inclusão de um prato, também para ele, enquanto português, mais pitoresco (leia-se geograficamente mais circunscrito e menos divulgado, mesmo entre os seus compatriotas), pelo que o introduz na sequência de sopas através da expressão "é de uso", sinónima de "é tradicional".

Como vimos, em Portugal a tradição do consumo de castanha circunscrevia-se às regiões produtoras do fruto. Mesmo aí, o seu estatuto na cozinha deve ser sempre equacionado como um recurso alternativo a outros ingredientes ou alimentos mais nobres da alimentação humana, com destaque para o pão. Quer isto dizer que uma sopa à base de castanha, em termos de leitura sociológica da mesa, deve ser tida como uma evidência de uma cozinha básica e "baixa" dos pobres, onde não havia disponibilidade para integrar o alimento primordial da "cozinha civilizada" e que permanecia na "alta cozinha" dos ricos: o pão. Por certo que, o que começara por ser uma necessidade (a substituição do pão de cereais por castanhas na confeção da sopa), em populações onde o fruto abundava, acabou por criar nesses consumidores uma memória gustativa responsável pelo papel determinante do gosto na preservação e transmissão de pratos regionais. Queremos com isto dizer que os autores de receituários ditos nacionais e regionais portugueses por nós analisados, ao incluírem essa sopa nas suas obras, fazem-no não tanto pela consciência desse papel de alimento de sobrevivência (que teve), mas movidos, sobretudo, por leituras regionais e etnográficas. Ainda que sejam muito escassos os indicadores objetivos dessas perspetivas de leitura, não estão de todo ausentes das obras por nós analisadas. É o caso do Caldo de castanhas piladas publicado por Maria de Lurdes Modesto (1981: 13), onde, para além da leitura regional decorrente da sua inclusão no cardápio tradicional de Entre-Douro-e-Minho, vem registado, em nota à receita, que se trata de comida tradicional em duas épocas específicas do ano: dia de São Bartolomeu e Quaresma. Provavelmente por o santo ter tido uma morte violenta (esfolado vivo e decapitado) às mãos dos infiéis, criou-se a crença popular de que, no dia da sua morte (24 de agosto), andando o demo à solta, as pessoas deviam ficar recolhidas em casa, o que as impedia de ir às hortas colher alimentos. Assim, valiam-se, ao que se depreende, de produtos de conserva, como é o caso das castanhas secas. Já o seu consumo na Quaresma e em especial na

181 Folheto desdobrável ilustrado por Carlos Botelho (1899-1982) e editado pelo Secretariado da Propaganda de Portugal para a Exposition internationale des Arts et Techniques appliqués à la vie moderne (Paris, 4-27 de novembro de 1937). O texto foi posteriormente publicado em tradução portuguesa, que consultámos e para a qual remetemos (Sampaio 1939: 13-19). 
Quinta-Feira Santa, segundo a recolha de informações orais publicada por Modesto, correspondia a uma forma de os cristãos se privarem de consumir os bens das hortas, deixando-os assim intactos para que Cristo os pudesse contemplar antes de ser crucificado.

Nos outros dois livros de culinária portuguesa estudados, a leitura prevalecente é a territorial, que, no caso da receita de Olleboma, vem exibida no próprio título (Sopa de castanha pilada à minhota, p. 50), enquanto no receituário de Maria Odette Cortes Valente é a inclusão em regiões que denuncia esse sentido ${ }^{182}$. Mas se atentarmos na descrição técnica do prato publicado pelo presidente da SPG, constatamos que o detalhe colocado na apresentação das formas de secagem do fruto e da remoção da pele para ser cozinhado é uma clara evidência de que, nesses anos 30 , estas eram já práticas arredadas do conhecimento e do quotidiano dos potenciais leitores da obra. À mesa dessa população de classe média-alta, maioritariamente urbana, a castanha aparecia como um fruto pitoresco, cujos métodos de preparação culinária se afiguravam redutos técnicos etnográficos. Ciente dessa realidade, Oliveira Bello começa por explicar que existem dois métodos de secagem da castanha, dando indicações precisas sobre o processo de secagem ao fumeiro, à partida o menos conhecido ${ }^{183}$. Ensina a remover a pele interior, depois de as castanhas estarem já secas, recorrendo à esfrega com sal, bem como a demolhá-las e limpá-las de gérmenes e de partes escurecidas.

Mantendo-nos na rubrica dos salgados, continuamos a encontrar no receituário de Olleboma o recheio de aves (perus, frangos, perdizes e patos) com a presença de castanhas (Castanhas para recheio de aves, p. 247), técnica culinária que conseguimos fazer recuar na literatura culinária portuguesa ao séc. XVIII (à obra de Lucas Rigaud). O interessante é observar que, publicando Bello um livro que, pelo título (Culinária portuguesa), pretende fixar o receituário da arte de cozinhar nacional, esta seja concebida não como domínio de uma culinária exclusivamente tradicional, de origem (real ou inventada) sobretudo rural (como virá a suceder com as recolhas de Modesto e Cortes Valente), mas como lugar de encontro e fusão (que efetivamente era e continua a ser) de várias influências. Ressalvamos esta aceção dialogante e interativa da arte culinária nacional - aberta às categorizações contrastivas, mas coexistentes, de "alta cozinha"/"baixa cozinha”, "cozinha nacional"/“cozinha estrangeira”

182 Entre Douro e Minho: Sopa de castanhas piladas (p. 420); Trás-os-Montes: Caldo de castanhas (p. 712), Sopa transmontana (p. 717); Mesão Frio (em Trás-os-Montes): Sopa de castanha pica (p. 715); Lousã (nas Beiras): Sopa de castanhas (p. 309); Tavira (no Algarve): Sopa de feijão com castanha (p. 224).

183 "As castanhas piladas são castanhas secas ao sol ou num caniço que se põe nas lareiras de um a um metro e meio pouco mais ou menos dos fogareiros ou fogões. Têm melhor sabor quando secas ao sol". 
- no momento em que tratamos do preparado de castanhas para recheio de aves, precisamente porque essa será uma técnica considerada de inspiração internacional, como enfatizaria uma década mais tarde Bertha Rosa Limpo, com as suas receitas de Recheio de castanhas para aves à francesa e Recheio de castanhas à italiana. Oliveira Bello, ao invés de acentuar, como Rosa Limpo, a inspiração estrangeira do preparado, enfatiza a incorporação do mesmo na "cozinha [portuguesa] dos territórios", uma vez que as suas castanhas para recheio de aves (p. 242) é que permitem completar a execução do Peru assado à lisboeta (pp. 209-210).

Repare-se, ainda, que o facto de na Culinária Portuguesa aparecerem pratos de clara importação estrangeira não deve ser interpretado como uma contradição, pois está em consonância com os princípios dos estatutos da Sociedade Portuguesa de Gastronomia ${ }^{184}$. Concordamos, por isso, com Philippe Meyzie (2010: 182), quando propõe que se aborde o tema das relações de outras cozinhas nacionais com a cozinha francesa sob o prisma não da "influência" (que coloca a tónica na transferência de elementos de uma cultura a outra, que se limitaria a recebê-los como tal), mas dos "trânsitos culturais", conceito em que se tem em conta as condições de receção e de apropriação ${ }^{185}$. Em suma, não há uma cozinha nacional portuguesa "pura", incólume ao diálogo transformador com as cozinhas de outros países.

Se passarmos agora à rubrica de doces da obra de Olleboma, a escassez de receituário com castanha torna-se evidente. $\mathrm{Na}$ Culinária portuguesa apenas figuram duas receitas em que o fruto é usado: Castanhas com ovos- moles de Aveiro (pp. 276-277) e Croquetes de castanhas (p. 321). Uma e outra são exemplares da "alta cozinha", ainda que a primeira vise, claramente, a promoção da "cozinha dos territórios", o que se obtém pelo uso de um doce regional (já então afamado) na confeção das conhecidas castanhas de ovos ${ }^{186}$, ao passo que, na segunda, o que sobressai é a apropriação da culinária francesa pelo receituário nacional. Além do termo técnico do preparado ser de origem francesa (croquette), pudemos encontrar no já mencionado livro de pastelaria de Urbain Dubois (Grand livre des pâtissiers et des confiseurs, 1884) a provável receita inspiradora dos (portugueses) Croquetes de castanhas: Croquettes de marrons à la vanille (p. 76). Não se trata, no entanto, de uma importação

184 Cf. Pasta 86 da SPG, consultada por Ana Proserpio. Vd. alínea f) do art. 4. ${ }^{\circ}$ dos referidos estatutos, onde se lê que o projeto da associação reside em "coligir elementos para a história da alimentação portuguesa nas suas características e nas suas influências estrangeiras" (sublinhado nosso).

185 Seguimos a definição de Ruggiu (2007: 386), segundo a qual os processos de apropriação devem ser entendidos como "formes par lesquelles la civilisation ou les groupes récepteurs transforment et déforment les apports pour les adapter à leur propre contexte culturel et à leurs propres besoins sociaux".

186 Sobre a história dos ovos moles de Aveiro, vd. Associação Cultural Confraria Gastronómica de S. Gonçalo de Aveiro (2002) e Serôdio et al. (2013). 
(influência direta) técnica, mas mais de um processo de apropriação, uma vez que, tanto a massa dos croquetes é diversa, como o acabamento final ${ }^{187}$.

Se quisermos indagar a expressividade do receituário da castanha naquele que é, no panorama português, o primeiro livro com o título consagrado à culinária nacional, teremos, no entanto, de recuar até o início do séc. XX, mais precisamente a 1902 , ano da $2 .^{\text {a }}$ edição da Cosinha portugueza ou Arte Culinária Nacional e preliminares annexos (Imprensa Académica, Coimbra) ${ }^{188}$. Obra coligida por um editor provavelmente pertencente à instituição religiosa promotora do livro, o Instituto do Pão de Santo António, reúne um conjunto de preparados oferecidos por senhoras que, à luz do código comportamental feminino da época, "preferiram" manter o anonimato. Do total de 795 receitas, apenas dois doces têm por ingrediente principal a castanha. Um deles entronca na tradicional e ancestral conserva de fruta em calda (Compota de castanhas, p. 186). O outro corresponde a uma categoria bastante abundante em diversos receituários, os biscoitos. Contudo, ao invés da receita apresentada atrás num manuscrito culinário do séc. XIX atribuído ao Pe. Joaquim Brito, os Biscoitos de castanhas (p. 238) da Cosinha portugueza não são um produto da culinária mimética, uma vez que incluem castanhas na massa.

Em suma, a presença muito pontual de receitas de castanha nestas duas obras fundadoras da literatura culinária nacional portuguesa (Cosinha portugueza e Culinária portuguesa) deve ser encarada, antes de mais, como uma evidência do uso muito residual do fruto na culinária das famílias das Senhoras que ofertaram aos editores/compiladores dos respetivos livros alguns exemplares do cardápio que tinham na conta de representativo da mesa do seu país. Nessa mesa, a castanha figura como um produto regional, acompanhamento de alta cozinha e mimo culinário doce.

Antes de finalizarmos a análise da marca literária da castanha em livros de cozinha nacional, vejamos como a primeira revista portuguesa de culinária confirma, durante os anos finais da ditadura do Estado Novo, a permanência do fruto tanto na cozinha popular, como na mesa refinada das elites. Num total de 175 números com receitas, a Banquete - Revista portuguesa de culinária publica 48 modos de preparar e servir castanhas. $\mathrm{O}$ entendimento geral do fruto como ingrediente típico da cozinha tradicional portuguesa confirma-

187 Nos croquetes de castanha, o fruto entra tanto na composição da massa (feita de puré de castanha cozida, açúcar pilé, gemas e manteiga fresca), como no recheio de cada unidade, que leva no meio uma castanha cozida inteira. O toque final de requinte está em comerem-se acompanhados por um molho de alperces. A receita francesa incorpora as castanhas apenas na massa, mas sob a forma de farinha de castanha, tendo por acabamento uma cobertura de pasta de açúcar aromatizado de baunilha.

188 Não foi possível, até à data encontrar nenhum exemplar da $1 .^{\mathrm{a}}$ ed. para um estudo detalhado daquela que é, também, a primeira (e das poucas) obras coletivas de culinária com fins caritativos publicadas em Portugal, vd. Soares (2018a). 
-se, sobretudo, através da sua inclusão na rubrica "Petiscos da nossa terra". Também a valência de fruto aproveitado para receitas mais elaboradas, servidas em momentos de maior cerimónia, vem patenteada através da presença de receitas à base de castanhas na rubrica "Há convidados". Por se tratar de um ingrediente de marcada sazonalidade, consideraremos igualmente como esse condicionalismo ditou o aparecimento de uma secção especializada em "Castanhas", publicada durante cinco anos nas estações de consumo tradicional do fruto, outono e início do inverno ${ }^{189}$.

A nossa análise da revista obedeceu, por conseguinte, a uma seleção de receituário expressivo das três "leituras" acabadas de enunciar do uso culinário da castanha. Começando pelo cardápio tradicional da rubrica "Petiscos da nossa terra", vejamos como do mesmo fazem parte "receitas fundadoras", ligadas aos territórios produtores do fruto. $\mathrm{Na}$ Banquete 9, deparamos com uma versão do caldo de castanhas, publicado com a designação que se torna mais generalizada no séc. XX: Sopa de castanhas $^{190}$. A diretora da revista, Maria Emília Cancella de Abreu, esclarece estarmos perante a "cozinha dos territórios", conforme se depreende da observação apresentada no comentário em que diz: "a sopa de castanhas - tão apreciada pelos beirões" (p. 16).

Nesse mesmo número, confirma-se o estatuto de fruto sazonal, cuja longevidade se prolonga através da conservação. Daí que figurem, na rubrica "Conserve para amanhã as frutas colhidas hoje" (p. 15), duas receitas doces cuja tradição de fabrico já vimos anteriormente mencionada em manuscritos e livros impressos: Castanhada e Doce de castanhas inteiras (guardadas em calda, dentro de boiões).

Só a análise desses cinco fascículos temáticos da castanha permite confirmar a saída do fruto do quotidiano da cozinha e a sua utilização sobretudo na culinária destinada a assinalar o extra-ordinário, rubrica de que fazem parte os doces (a que justamente se chamaram desde muito cedo "mimos"). Ou seja, do total de 29 receitas publicadas nesse grupo de revistas, apenas uma não é um preparado doce ${ }^{191}$. O desconhecimento deste fruto, decorrente da redução da castanha a alimento etnográfico, é outra leitura que se retira das entrelinhas das explicações que acompanham as receitas quanto à tipologia dos frutos, formas de conservação em cru e derivados disponíveis no mercado.

189 Vd. dezembro de 1967 (n. ${ }^{\circ}$ 94); dezembro de 1968 (n. $\left.{ }^{\circ} 106\right)$; dezembro de 1970 (n.o 130); novembro de 1971 (n. $\left.{ }^{\circ} 141\right)$; novembro de 1972 (n. ${ }^{\circ} 153$ ).

190 Vd. Banquete 9, nov. 1960, pp. 16-17. Voltamos a encontrar, na Banquete 83 (jan. 1967), outra receita da categoria das "sopas”, numa rubrica cujo título (“Sopa quente!!! Tempo frio!!!") remete para o consumo do fruto na estação imediatamente seguinte à sua colheita. Note-se que a consistência aveludada do preparado terá levado à preferência pela denominação "puré" em vez de "sopa" ou "caldo": Puré de castanhas (p. 8).

191 Na verdade, a exceção corresponde a uma sugestão sobre como conservar a fruta em cru sem se deteriorar ("conserva de castanhas" em barricas com areia, Banquete 130, p. 10). 
De facto, nas pp. 10-11 da Banquete 130, prestam-se esclarecimentos gerais sobre calibre e variedades do produto, indicando existirem duas categorias de castanhas: as maiores, que ocupam por inteiro um ouriço, "conhecidas em França por «marrons»"; as menores, à razão de duas a três por ouriço, “designadas por «chataignes»". Repare-se que a própria remissão para o universo cultural francês é reveladora do perfil sociocultural do público-alvo da revista. Tratar-se-iam de mulheres burguesas, residentes em cidades e seguidoras das modas ditadas por França ${ }^{192}$.

Importa ainda ter presente que, em pleno séc. XX, permanece a associação do interesse gastronómico da castanha às vantagens dietéticas do seu consumo, pois a Diretora antecedeu as palavras acabadas de citar da menção de que "as castanhas são muito nutritivas". Escalpelizando o conteúdo informativo do trecho citado, repare-se como aí se evidencia o consumo do fruto em contextos culturais diversos. Além da "receita fundadora", das castanhas assadas - cujo uso generalizado entre a população portuguesa se assinala - há a referência à sua presença marcante na gastronomia doceira (que pode ser nacional ou internacional) e à identidade de cozinhas portuguesas regionais, típicas dos meios rurais, neste caso associadas a outro prato fundador, o da sopa de castanhas ${ }^{193}$. Igualmente nessa matriz fundadora devemos incluir as receitas que ensinam a conservar o fruto para lá da sua duração em fresco, caso de duas receitas de Castanhada ${ }^{194}$ e de uma de Conserva de castanhas ${ }^{195}$. Porém, como a secção "Castanhas" tem um perfil abrangente, nela se reúnem ainda receitas que ilustram a presença do fruto em doçaria ligada a várias geografias europeias - francesa ${ }^{196}$ e húngara ${ }^{197}$ - e a sua presença numa culinária apostada na elaboração técnica ${ }^{198}$. A evidência que o requinte de um prato, por vezes,

192 Ignorantes das valências alimentares do fruto fora do universo da culinária requintada (de proveniência ou inspiração estrangeira), essas leitoras merecem as seguintes palavras da Diretora da revista: "Embora seja muito habitual entre nós comê-las assadas, também se preparam deliciosas sobremesas e tanto em Trás-os-Montes como na Beira, é costume comer no Inverno uma sopa de castanhas que, só por si vale uma refeição completa. Esta sopa é muito gostosa, embora ainda não seja hábito confeccioná-la na cidade, mas sòmente no campo" (Banquete 130, p. 10).

193 Este é um prato que vimos figurar também na secção "Petiscos da nossa terra" (no já mencionado n. ${ }^{9}$ ), mas também na secção "Ementa do mês", no n. ${ }^{\circ}$ 141, p. 24 (precisamente publicado no mês consagrado à colheita do fruto: novembro, de 1971).

194 Banquete 9, p. 15: Castanhada I (justamente incluída na secção intitulada "Conserve para amanhã os frutos colhidos hoje"); Banquete 130, p. 10: Castanhada II.

195 Banquete 130, p. 10.

196 Bolo francês de castanhas (Banquete 153, p. 21); Creme francês de castanha, Creme francês de castanha com caramelo e leite, Creme francês de castanha com chocolate (Banquete 141, p. 12); Pudim de castanhas à lionesa (Banquete 106, p. 9).

197 Bolo huingaro de castanhas (Banquete 153, p. 21).

198 Pudins soufflés de castanha à Magnifico (Banquete 130, p. 11), Tarte chiffon de castanhas (Banquete 153, p. 21), Tronco de castanhas (Banquete 106, p. 9), Bolachas com castanha e nata (Banquete 153, p. 21) e Bolachas suecas com creme de castanhas (Banquete 153, p. 21). 
decorre da junção a uma confeção simples de um preparado conotado com a "alta cozinha" vemo-la, se confrontarmos a inclusão por Cancella de Abreu da Aletria de castanha ${ }^{199}$ na rubrica "Se tem pouco tempo" com a Aletria de castanhas com chantilly ${ }^{200}$, publicada na secção "Ementa de cerimónia".

Bom exemplo da "alta cozinha" doceira à base de castanha é o Pudim de castanhas com ananás (Banquete 20, outubro 1961, p. 13), preparado cujo requinte ressalta da própria inclusão, na receita, de uma especialidade francesa de castanhas, as "marrons glacés". Citamos de seguida a observação final da receita, na medida em que confirma residir na cobertura do bolo a evidência visual do requinte ou caráter "cerimonioso" da receita:

Deita-se um pouco de molho de ananaz sobre o doce, e, à parte, serve-se, querendo, chantilly ou molho de chocolate quente. Mas se se quiser servir tal e qual, embora menos cerimonioso, é óptimo na mesma [...].

A técnica de caramelizar as castanhas e dispô-las em pinha, que já registámos atrás, é mais um dos preparados de doçaria requintada publicado na secção "Há convidados" (Pinha de castanhas e amêndoas ${ }^{201}$ ). Dessa mesma rubrica fazem parte outros doces finos e elaborados, a saber: Pão-de-ló recheado de castanhas ${ }^{202}$, Pudim esplêndido de castanhas e amêndoas ${ }^{203}$, Sonho de chocolate com castanhas ${ }^{204}$, Recheio doce de castanhas com chantilly ${ }^{205}$, Vacherin de marrons glacés. Tanto o uso de termos culinários técnicos franceses como a escolha de vocabulário português a remeter para o "extraordinário" (adj. "esplêndido"; subst. "sonho") estão ao serviço de uma semiótica do requinte culinário. Aliás, a conceção da castanha como ingrediente identitário da "alta cozinha" francesa vem plasmada na inclusão de uma receita de Sorvete de pêra e castanha numa secção precisamente intitulada "Gastronomia francesa" 206 .

Todavia, não é apenas nas sobremesas que a arte decorativa é colocada ao serviço do refinamento da apresentação de uma iguaria. Prova disso encontramo-la numa outra receita da "alta cozinha" da castanha, precisamente incluída na secção "Há convidados": Ganso estufado, com puré de castan ha"207. Recomenda-se que o puré de guarnecimento seja "passado pela seringa", numa nítida aproximação entre as técnicas decorativas dos pratos doces e

\footnotetext{
Banquete 117, p. 11.

Banquete 69, p. 4.

Banquete 118, p. 19.

Banquete 118, p. 19.

Banquete 118, p. 18.

204 Banquete 81, p. 13.

205 Banquete 166, p. 16.

206 Banquete 140, p. 15.

207 Banquete 22, p. 13.
} 
dos salgados. Ainda sem sairmos da tradição da "alta cozinha", deparamos com as aves recheadas com castanhas, que, consoante a sua inclusão em determinada secção, assim a Diretora da revista as "cataloga" de cozinha tradicional portuguesa ou de cozinha de cerimónia (secção onde prevalece a culinária internacional). Se o ganso, menos comum nas capoeiras e mercados portugueses, é remetido para a rubrica "Há convidados" 208 , já o peru, ave com uma presença obrigatória nos receituários portugueses desde a Época Moderna, tanto figura na rubrica enunciada ${ }^{209}$, como nos "Petiscos da nossa terra". A integração do assado de peru na identidade culinária portuguesa fora localizada por Olleboma, em meados dos anos 30, em Lisboa (com a sua receita de Peru recheado à Lisboeta), mas via-se, no final da década de 70, plenamente concretizada, com a promoção na Banquete a prato nacional (Peru assado à Portuguesa ${ }^{210}$ ).

Evidenciando a atenção da Diretora da revista às modas alimentares do seu tempo, não estranhamos a inclusão, na secção Pratos vegetarianos, da receita Castanhas estufadas com couves-de-bruxelas ${ }^{211}$. Note-se a atenção de Maria Emília Cancella de Abreu à necessidade de adequar o receituário proposto à oferta sazonal dos ingredientes, donde publicar esta proposta em outubro, mês em que começaria a haver disponibilidade do fruto fresco no mercado.

Passando, agora, à análise da presença da castanha em obras cujo tema é a cozinha tradicional e regional portuguesa, com que finalizaremos o nosso estudo, impõe-se recordar o retrato que atrás foi feito das regiões produtoras em Portugal ${ }^{212}$. Assim, em sintonia com a sobrevivência mais expressiva do plantio em Trás-os-Montes, a Cozinha Tradicional Portuguesa de Maria de Lourdes Modesto contempla receituário apenas para essa região, a zona limítrofe (de Entre-Douro-e-Minho) e as Beiras. Já o crescimento da cultura, do último quartel desse século em diante, reflete-se no aumento significativo de regiões para as quais Maria Odette Cortes Valente, no seu Tesouro da cozinha regional portuguesa, regista receitas com castanha, num total de oito. Às três anteriores, acrescenta Extremadura, Ribatejo, Alentejo, Algarve e Madeira. Ao nível dos preparados, verificamos que a tendência foi para o "doce fruito" se impor, sobretudo na categoria dos doces (nove contra quatro variedades de salgados). Para facilitar a rápida perceção destes dados, elaborámos duas tabelas similares (uma para pratos doces e outra para pratos salgados), que apresentamos de seguida ${ }^{213}$.

\footnotetext{
208 Banquete 46, p. 18: Ganso recheado com castan has.

209 Banquete 174, p. 13: Peru assado com recheios à escolha.

210 Banquete 106, p. 10.

211 Banquete 152, p. 27.

212 Cf. supra, no termo do ponto 1.1.

213 Repare-se que a leitura das tabelas deve ser feita tanto na horizontal (o que permite
} 
Um doce e nutritivo fruto: a castanha na história da alimentação e da gastronomia portuguesas

\begin{tabular}{|c|c|c|c|c|c|}
\hline \multirow{2}{*}{ Região } & \multirow{2}{*}{ Localidade } & $\begin{array}{l}\text { Categoria } \\
\text { culinária }\end{array}$ & $\begin{array}{l}\text { Categoria } \\
\text { culinária }\end{array}$ & Categoria culinária & \multirow{2}{*}{$\begin{array}{l}\text { TOTAL } \\
\text { por região }\end{array}$} \\
\hline & & Sopas & $\begin{array}{c}\text { Pratos de } \\
\text { carne }\end{array}$ & Acompanhamentos & \\
\hline $\begin{array}{c}\text { Entre Douro } \\
\text { e Minho }\end{array}$ & & $\begin{array}{c}\text { “Caldo de } \\
\text { castanhas } \\
\text { piladas" } \\
\text { (Modesto: } \\
\text { 13); "Sopa } \\
\text { de castanhas } \\
\text { piladas" } \\
\text { (Valente: } 420 \text { ) }\end{array}$ & $\begin{array}{c}\text { "Rojões à } \\
\text { moda do } \\
\text { Minho" } \\
\text { (Modesto: } \\
25)\end{array}$ & & 2 \\
\hline \multirow[t]{5}{*}{$\begin{array}{c}\text { Trás-os- } \\
\text { Montes (e } \\
\text { Alto Douro)1 }\end{array}$} & & $\begin{array}{c}\text { “Caldo de } \\
\text { castanhas" } \\
\text { (Valente: 712) }\end{array}$ & $\begin{array}{c}\text { "Carne de } \\
\text { porco es- } \\
\text { tufada com } \\
\text { castanhas" } \\
\text { (Modesto: } \\
60)\end{array}$ & & \multirow{5}{*}{6} \\
\hline & \multirow{3}{*}{$\begin{array}{l}\text { Mesão } \\
\text { Frio }\end{array}$} & $\begin{array}{c}\text { "Sopa de } \\
\text { castanha pica" } \\
\text { (Valente: 715) }\end{array}$ & & & \\
\hline & & $\begin{array}{c}\text { "Sopa trans- } \\
\text { montana" } \\
\text { (Valente: } 717 \text { ) }\end{array}$ & & & \\
\hline & & & $\begin{array}{c}\text { "Rojões" } \\
\text { (Valente: } \\
748)\end{array}$ & & \\
\hline & Bragança & & $\begin{array}{c}\text { "Rojões } \\
\text { com cas- } \\
\text { tanhas" } \\
\text { (Valente: } \\
749)\end{array}$ & & \\
\hline
\end{tabular}

aferir, para uma mesma região, a identificação das categorias contempladas em cada uma das duas rubricas culinárias - doces e salgados), como na vertical (permitindo perceber a incidência de uma mesma categoria de preparado nas regiões elencadas). A frente de cada nome de receita, colocámos, dentro de parênteses, o apelido da autora da obra, seguido de dois pontos e do(s) número(s) de página(s) em que aquela está publicada na respetiva obra. 
Maria Helena da Cruz Coelho, Carmen Soares

\begin{tabular}{|c|c|c|c|c|c|}
\hline \multirow[t]{2}{*}{ Beiras } & Lousã & $\begin{array}{c}\text { "Sopa de } \\
\text { Castanhas" } \\
\text { (Valente: 309) }\end{array}$ & & \multirow{2}{*}{$\begin{array}{l}\text { "Arroz de cas- } \\
\text { tanhas piladas" } \\
\text { (Valente: } 330 \text { ) }\end{array}$} & \multirow[t]{2}{*}{2} \\
\hline & $\begin{array}{l}\text { Castro } \\
\text { d'Aire }\end{array}$ & & & & \\
\hline \multicolumn{6}{|l|}{ Ribatejo } \\
\hline \multicolumn{6}{|l|}{ Alentejo } \\
\hline \multirow[t]{2}{*}{ Algarve } & Tavira & $\begin{array}{c}\text { "Sopa de } \\
\text { feijão com } \\
\text { castanhas" } \\
\text { (Valente: } 224)\end{array}$ & & & \multirow[t]{2}{*}{2} \\
\hline & Altura & & & $\begin{array}{c}\text { "Arroz de casta- } \\
\text { nhas" (Valente: } \\
237)\end{array}$ & \\
\hline \multicolumn{2}{|c|}{ Total/categoria } & 7 & 4 & 2 & \\
\hline
\end{tabular}

Tabela 1: Receitas salgadas

\begin{tabular}{|c|c|c|c|c|c|c|c|}
\hline Região & Localidade & Bolinhos & $\begin{array}{c}\text { Doces de } \\
\text { Colher }\end{array}$ & $\begin{array}{c}\text { Doces de } \\
\text { fruta }\end{array}$ & $\begin{array}{c}\text { Doces “mi- } \\
\text { méticos" }\end{array}$ & Outros & Total \\
\hline $\begin{array}{c}\text { Entre Douro } \\
\text { e Minho }\end{array}$ & & & & & & \\
\hline
\end{tabular}


Um doce e nutritivo fruto: a castanha na história da alimentação e da gastronomia portuguesas

\begin{tabular}{|c|c|c|c|c|c|}
\hline \multirow{7}{*}{$\begin{array}{l}\text { Trás-os- } \\
\text { Montes } \\
\text { (e Alto } \\
\text { Douro)2 }\end{array}$} & \multirow{2}{*}{ Mesão Frio } & $\begin{array}{c}\text { "Falacha" } \\
\text { (Valente: } \\
762)\end{array}$ & & & \multirow{7}{*}{7} \\
\hline & & $\begin{array}{l}\text { "Bolos de } \\
\text { castanhas" } \\
\text { (Valente: } \\
768)\end{array}$ & & & \\
\hline & \multirow{5}{*}{$\begin{array}{c}\text { Torre de } \\
\text { D. Chama }\end{array}$} & $\begin{array}{c}\text { "Covilhetes" } \\
\text { (Valente: } \\
775)\end{array}$ & & & \\
\hline & & & $\begin{array}{c}\text { "Marmelada } \\
\text { de castanhas } \\
\text { à antiga" } \\
\text { (Valente: } \\
785)\end{array}$ & & \\
\hline & & & & $\begin{array}{c}\text { "Castanhas } \\
\text { assadas" } \\
\text { (Valente: } \\
786)\end{array}$ & \\
\hline & & & & $\begin{array}{c}\text { "Castanhas } \\
\text { assadas } \\
\text { no forno" } \\
\text { (Valente: } \\
786)\end{array}$ & \\
\hline & & & & $\begin{array}{c}\text { "Castanhas } \\
\text { cozidas" } \\
\text { (Valente: } \\
786)\end{array}$ & \\
\hline
\end{tabular}


Maria Helena da Cruz Coelho, Carmen Soares

\begin{tabular}{|c|c|c|c|c|c|c|c|}
\hline \multirow{4}{*}{ Beiras } & Viseu & & & & $\begin{array}{l}\text { "Castanhas } \\
\text { doces de } \\
\text { Viseu" } \\
\text { (Modesto: } \\
\text { 104) }\end{array}$ & & \multirow{4}{*}{4} \\
\hline & Penedono & & $\begin{array}{l}\text { "Doce de } \\
\text { castanhas" } \\
\text { (Valente: } \\
380)\end{array}$ & & & & \\
\hline & Lousã & $\begin{array}{l}\text { "Bolinhos } \\
\text { de cas- } \\
\text { tanhas" } \\
\text { (Valente: } \\
401)\end{array}$ & & & & & \\
\hline & Beira Alta & & & $\begin{array}{c}\text { "Marmelada } \\
\text { de castanha" } \\
\text { (Valente: } \\
415)\end{array}$ & & & \\
\hline Estremadura & Alenquer & & $\begin{array}{c}\text { "Arroz de } \\
\text { castanhas } \\
\text { piladas" } \\
\text { (Valente: } \\
569 \text { ) }\end{array}$ & & & & 1 \\
\hline Ribatejo & Tomar & & & & $\begin{array}{c}\text { "Castanhas } \\
\text { doces" } \\
\text { (Valente: } \\
696)\end{array}$ & & 1 \\
\hline Alentejo & Portalegre & & $\begin{array}{c}\text { “Sopa de } \\
\text { Castanhas } \\
\text { doces" } \\
\text { (Valente: } \\
185)\end{array}$ & & & & 1 \\
\hline Algarve & & & & & & & \\
\hline Madeira & & $\begin{array}{c}\text { Bolinhos de } \\
\text { castanha" } \\
\text { (Valente: } \\
622 \text { ) }\end{array}$ & & & & & 1 \\
\hline Total $/ 1$ & tos & 5 & 3 & 2 & 2 & 3 & \\
\hline
\end{tabular}

Tabela 2: Receitas doces 
Retomando o fio condutor da análise adotada para a literatura culinária anterior, verificamos a confirmação de que o núcleo de "receituário fundador" está presente nas coletâneas de cozinha tradicional portuguesa: castanhas cozidas e assadas; sopas de castanha (mesmo na variante do fruto pilado ${ }^{214}$ ); castanhas a acompanhar carne de porco (também no caso especial dos rojões); castanhas de doce (a chamada "marmelada" de castanhas); castanhas em pão (doce: a falacha). Observa-se, neste universo do tradicional e regional, a esperada ausência de pratos de maior requinte, próprios da cozinha rica das classes mais elevadas, como é o caso do peru (ou outras aves) recheado com castanhas. Notamos que a disponibilidade do fruto terá mesmo levado à sua combinação com o arroz, um cereal de longa tradição na mesa portuguesa, originando receitas de Arroz de castanhas (numa zona de serra da Beira Litoral - Castro d'Aire - e em Altura, na costa algarvia). Já ao nível dos doces, é de assinalar a permanência das seculares castanhas doces "fingidas", chamadas castanhas pela forma (que imita o tão apreciado fruto), bem como a ausência das complexas e refinadas receitas de inspiração/influência estrangeira. Contudo, o uso do fruto na doçaria dá ainda origem a criações a partir de receituário mais tradicional, caso do Arroz doce de castanhas piladas.

\section{Considerações finais}

Terá sido temeridade propor uma leitura sucinta da culinária da castanha ao longo de 26 séculos, da Antiguidade clássica ao Portugal contemporâneo. Assumimola como um abrir de perspetivas futuras de outras reflexões e interpretações.

No que deixámos esboçado, conhecem-se percursos diacrónicos do consumo da castanha, essencialmente como um fruto ou uma farinha, nas civilizações grega e romana, que nos influenciaram, e no emergente Portugal medieval. Mais universalmente poderemos acentuar que se sublimou neste espaço ocidental peninsular o papel e protagonismos deste fruto na faixa mediterrânica helenizada e romanizada, que dos Cárpatos, passando pelo Cáucaso e as áreas alpina e pirenaica, alcança a Península Ibérica.

Acentuaram-se as inter-relações entre a culinária e a dietética, tomando como base sobretudo as receitas deste fruto na época moderna. Avançámos por livros de receitas e revistas da Época Contemporânea que elegiam a castanha como matéria-prima, seguindo grelhas operatórias como "alta cozinha"/"baixa cozinha", "cozinha nacional"/ "cozinha estrangeira", "cozinha dos territórios", "cozinha de autor", "cozinha dos afetos". Conhecemo-la como ingrediente de

214 Repare-se no uso do sinónimo "pica", a par de "pilada" (ambas em Valente). 
pratos salgados (sopas, pratos de carne, recheios de aves, acompanhamento) ou doces (sobremesas de colher, doces de fruta, doces "miméticos", bolos, biscoitos).

A longa permanência de alguns destes pratos deu corpo à identificação de um "receituário fundador" da castanha: assada e cozida, em sopa, no acompanhamento ou recheio de carnes, em conservas doces.

A presença em preparados de inspiração estrangeira permitiu identificar a pertinência de analisar a culinária dos receituários dos livros portugueses à luz do trânsito cultural com outras cozinhas europeias.

Percebemos mesmo como, de um consumo da castanha pela gente simples e humilde da montanha, a castanha passou a estar presente, quase como um fruto excêntrico e pouco conhecido, nas mesas aristocráticas e da alta burguesia.

Cruzando essencialmente fontes escritas de natureza vária ao longo dos séculos, a castanha serviu-nos de mote e foi tema de eleição nesta longa caminhada temporal pela história cultural e civilizacional, rica em desafios de questionamentos múltiplos, que é a história da alimentação.

\section{REFERENCIAS}

Fontes MANUSCRITAS

Lisboa, ANTT, Chancelaria de D. Dinis, liv. 3, fol. 29v.

\section{FonTES IMPRESSAS}

Amigues, S. (1989), Théophraste. Recherches sur les plantes, Tome II, Livres III-IV, Les Belles Lettres, Paris.

Annona ou Mixto Curioso: folheto semanal que ensina o methodo de cosinha e copa, com um artigo de recreação, T. 1, n. ${ }^{\circ} 1$ (1836) - T. 3, n. ${ }^{\circ} 36$ (1837), Lisboa.

Arnaut, S. D., Manupella, G. (1967), O "Livro de Cozinha" da Infanta D. Maria de Portugal, Imprensa Nacional-Casa da Moeda, Coimbra.

Audot, L.-E. (1900, 78. ${ }^{\mathrm{a}}$ ed.), La cuisinière de la campagne et de la ville ou la nouvelle cuisine économique, Librairie Audot, Paris.

Banquete. Revista portuguesa de culinária (1960-1974, 1976), Maria Emília Cancella de Abreu (diretora), Empresa Tipográfica Casa Portuguesa, Lisboa.

Barros, A. L. (2013), As receitas de cozinha de um frade português do séc. XVI, Imprensa da Universidade de Coimbra, Coimbra.

Barros, A. L. (2016), Remédios vários e receitas aprovadas. Segredos vários, Imprensa da Universidade de Coimbra, Coimbra.

Braga, I. D. B. (2015), Sabores É Segredos. Receituários conventuais portugueses da Época Moderna, Imprensa da Universidade de Coimbra, Coimbra, São Paulo.

Bello, A. M. O. (1936), Culinária portuguesa, Assírio e Alvim, Lisboa. 
Cabral, M. I. V. (2000), O Livro de Receitas da Última Freira de Odivelas, Editorial Verbo, Lisboa, São Paulo.

CHDAIII = Ventura, L., Oliveira, A. R. (2006), Chancelaria de D. Afonso III, liv. I, vol. 2, Imprensa da Universidade de Coimbra, Coimbra.

CHDAIV = Marques, A. H. O. (1992), Chancelarias Portuguesas. D. Afonso IV, vol. II (1336-1340), INIC - Centro de Estudos Históricos/Universidade Nova de Lisboa, Lisboa.

CHDJI = Dias, J. J. A. (2004), Chancelarias Portuguesas. D. João I, vol. I, t. 1 (1384-1385), Centro de Estudos Históricos-Universidade Nova de Lisboa, Lisboa.

CHDJI = Dias, J. J. A. (2005), Chancelarias Portuguesas. D. João I, vol. II, t. 1 (1385-1392), Centro de Estudos Históricos-Universidade Nova de Lisboa, Lisboa.

CHDJI = Dias, J. J. A. (2005), Chancelarias Portuguesas. D. João I, vol. II, t. 3 (1391-1407), Centro de Estudos Históricos-Universidade Nova de Lisboa, Lisboa.

CHDJI = Dias, J. J. A. (2006), Chancelarias Portuguesas. D. João I, vol. III, t. 1 (13851410), Centro de Estudos Históricos-Universidade Nova de Lisboa, Lisboa.

CHDJI = Dias, J. J. A. (2006), Chancelarias Portuguesas. D. João I, vol. III, t. 3 (14021418), Centro de Estudos Históricos-Universidade Nova de Lisboa, Lisboa.

Collecção = Serra,J. C. (1816), Colleç̧ão de livro ineditos de historia portugueza dos reinados de D. Dinis, D. Affonso IV, D. Pedro I e D. Fernando, t. IV, Officina da Academia Real das Sciencias de Lisboa, Lisboa.

Cosinha portugueza ou arte culinária nacional e preliminares anexos. Producto aplicado a um fim piedoso (1902, 2. ${ }^{\text {a }}$ ed.), Imprensa Académica, Coimbra.

CPRDAIV = Marques, A. H. O. et al. (1982), Cortes Portuguesas. Reinado de D. Afonso IV (1325-1357), INIC, Lisboa.

CPRDAV = Dias, J.J.A., Pinto, P. (2016), Cortes Portuguesas. Reinado de D. Afonso V (Cortes de 1439), Centro de Estudos Históricos-Universidade Nova de Lisboa, Lisboa.

DP, I; DP, Suplemento = Marques,J.M.S. (1944), Descobrimentos Portugueses. Documentos para a sua história, vol. I; Suplemento ao vol. I, Instituto de Alta Cultura, Lisboa.

Dubois, U. (1884), Grand livre des pâtissiers et des confiseurs, Flammarion, Paris.

HFAC = Neves, C. M. L. B. (1983), História Florestal, Aquícola e Cinegética. Colectânea de documentos existentes no Arquivo Nacional da Torre do Tombo. Chancelarias Reais, vol. IV (1495-1521), Ministério da Agricultura, Florestas e Alimentação, Secretaria de Estado das Florestas, Direcção-Geral das Florestas, Lisboa.

Isalita, pseud. (1925), Doces e cozinhados: receitas escolbidas, Bertrand (5. ${ }^{\mathrm{a}} \mathrm{ed} .1937$ ?), Sá da Costa (25. a ed. 1977), Lisboa.

Latim Medieval = Obras de Maria Helena da Rocha Pereira, Latim Medieval (2014), Fundação Calouste Gulbenkian, Imprensa da Universidade de Coimbra, Coimbra.

Limpo, B. R. (1955, 15. ${ }^{\mathrm{a}}$ ed.), O livro de Pantagruel: cozinha, doçaria, bebidas, Temas e Debates, Lisboa.

LPA = Rodrigues, M. T. C. (1974), Livro das posturas antigas, Câmara Municipal de Lisboa, Lisboa.

Modesto, M. L. (1981), Cozinha tradicional portuguesa, Editorial Verbo, Lisboa. 
Plantier, P. (1870), O cosinheiro dos cozinheiros, collecção de mais de 1500 receitas usuaes, fáceis e económicas, de cozinha, copa, salsicharia, pastellaria e confeitaria com as mais importantes notícias relativas à alimentação e conserva das substâncias alimentícias, obra ornada com 47 gravuras (dedicado) às boas donas de casa, Nova Edição, Lisboa.

PMH, Inquisitiones I = Portugaliae Monumenta Historica, Inquisitiones (1888), vol. I, Olisipone Typis Academicis, Lisboa.

Rodgers, R. H. (1975), Palladius, Opus agriculturae, de veterinaria medicina, de insitione, BSB Teubner, Leipzig.

Tavares, P.M.(1995), Doces e manjares do séc. XIX. O Livro do Padre Brito, Fora de Texto, Coimbra. Valente, M. O. C. (2008), Tesouro da Cozinha Regional Portuguesa, Temas e Debates, Lisboa.

\section{Estudos}

Albala, K. (2002), Eating Right in the Renaissance, University of California Press, Berkeley. Albala, K. (2012), “Cookbooks as Historical Documents”, in J. M. Pilcher (ed.), The Oxford Handbook of Food History, Oxford University Press, Oxford, 227-239.

Albuquerque, L., Pericão, G. (1986), Gabriel Soares de Sousa, Notícia do Brasil, direção e comentário de Luís de Albuquerque, transcrição em português atual de Maria da Graça Pericão, Alfa, Lisboa.

André, J. (1961), L'alimentation et la cuisine à Rome, Les Belles Lettres, Paris.

Associação Cultural Confraria Gastronómica de S. Gonçalo de Aveiro (ed.) (2002), Ovos moles de Aveiro, Câmara Municipal de Aveiro, Aveiro.

Arano, L.C.(1976), The medieval health handbook: Tacuinum Sanitatis, George Braziller, New York.

Asfora, W. (2014), Apício: História e incorporação de um livro de cozinha na Alta Idade Média, Alameda, São Paulo.

Belo Luís, S. (2012), "Recordações de Isalita: As histórias da autora de Doces e cozinhados, contadas na primeira pessoa por quem a serviu”, Visão Gourmet outono/inverno: 30-32.

Bessière,J., Tibère L. (2011), "Editorial: Patrimoines alimentaires”, Anthropology of food 8, s.p.

Barros, H. G. (1945, 2. a ed.), História da Administração Pública em Portugal nos séculos $X I I$ e XV, t. II, dirig. por T. de S. Soares, Sá da Costa, Imprensa Nacional, Lisboa.

Barros, H. G. (1949, 2. a ed.), História da Administração Pública em Portugal nos séculos XII e XV, t. VII, dirig. por T. de S. Soares, Sá da Costa, Imprensa Nacional, Lisboa.

Barros, H. G. (1950, 2. a ed.), História da Administração Pública em Portugal nos séculos XII e XV t. IX, dirig. por T. de S. Soares, Sá da Costa, Imprensa Nacional, Lisboa.

Braga, I. M. R. M. D. (2008), “Culinária no feminino: os primeiros livros de receitas escritos por portuguesas”, Caderno Espaço Feminino 19.1: 117-141.

Braga, I. D., Ornellas e Castro, I. (2013), “Saberes e fazeres de Berta Rosa Limpo. A construção de um êxito: O Livro de Pantagruel', Faces de Eva 29: 45-66.

Braudel, F. (1961), "Alimentation et catégories de 1'histoire", in Annales. Économies, Societés, Civilisations 16.4: 723-728.

997), "Cooking up stories: narrative elements in community cookbooks", in Recipes 
for Reading: Community Cookbooks, Stories, Histories, University of Massachusetts, Amhurst, 29-51.

Brill's New Pauly (2002-...), Hubert Cancik and Helmuth Schneider (Antiquity) and Manfred Landfester (Classical Tradition), English translation edited by Christine F. Salazar (Antiquity) and Francis G. Gentry (Classical Tradition), Brill, Leiden-Boston.

Bower, A. (ed.) (1997), "Cooking up stories: narrative elements in community cookbooks", in Recipes for Reading: Community Cookbooks, Stories, Histories, University of Massachusetts, Amhurst, 29-51.

Bruegel, M., Laurioux, B. (eds.) (2002), Histoire et identités alimentaires en Europe, Hachette Littératures, Paris.

Cardoso, J. F., Pereira, M. P. (2007), “O castanheiro de fruto em Portugal”, in J. GomesLaranjo et al. (eds.), Castanheiros, UTAD, Vila Real, 23-41.

Ceccarelli, G., Grandi, A., Magagnoli, S. (2010), “The 'Taste' of Typicality”, Food E̋ History 8.2: 45-76.

Cherubini, G. (1981) "La civiltà del castagno alla fine del Medioevo", Archeologia Medievale 8: 247-280.

Claro, S. (2013), “II Parte: Arte de cozinha ou methodo de fazer guizados. Um receituário do séc. XVII na Livraria do Mosteiro de Tibães”, in A. Ramos, S. Claro, Alimentar o corpo, saciar a alma: ritmos alimentares dos monges de Tibães, século XVII, Edições Afrontamento, Porto.

Conedera, M., Krebs, P., Tinner,W., Pradella, M., Torriani, D. (2004), “The cultivation of Castanea sativa (Mill.) in Europe, from its origin to its diffusion on a continental scale”, Veg Hist Archaeobot 13: 161-179.

Cortonesi, A. (2001), "Autoconsumo e mercado: a alimentação rural e urbana na Baixa Idade Média”, in J.-L. Flandrin, M. Montanari (eds.), História da Alimentação. 2. Da Idade Média aos tempos actuais, Terramar, Lisboa, 31-41.

Dalby, A. (2000), Dangerous tastes. The story of the spices, University of California Press, Berkeley-Los Angeles.

Dalby, A. (2003), Food in the Ancient world. From A to Z, Routledge, London-New York.

Fischler, C. (1988), "Food, self and identity”, Social Science Information 27.2: 275-292.

Fitch,J. G. (2013), Palladius: The Work of Farming (Opus agriculturae), Prospect Books, Totnes.

Flandrin, J.-L. (2001), “Condimentação, cozinha e dietética nos séculos XIV, XV e XVI”, in J.-L. Flandrin, M. Montanari (eds.), História da Alimentação. 2. Da Idade Média aos tempos actuais, vol. II, trad. para port. de Maria da Graça Pinhão e Catarina Gândara, Terramar, Lisboa, 95-110.

García Soler, M.J. (2001), El arte de comer en la antigua Grecia, Biblioteca Nueva, Madrid.

Gomes, J. P. (2016), "Propriedades e usos do açafrão na Idade Moderna em Portugal”, Revista de História Helikon 3.5: 60-72.

Gonçalves, I. (1965), "Fossadeira”, in J. Serrão (ed.), Dicionário de História de Portugal, vol. II, Iniciativas Editoriais, Porto, 285-286.

Grande Enciclopédia Portuguesa e Brasileira (1940-...), Editorial Enciclopédia, Lisboa-Rio 
de Janeiro.

Greyzen, A. (2014), "Food Studies and the Heritage Turn: a Conceptual Repertoire", Food Eं History 12.2: 67-96.

Grieco, A. J. (1992), "From the Cookbook to the Table: a Florentine Table and Italian Recipes of the Fourteenth and Fifteenth Centuries", in C. Lambert (ed.), Du manuscrit à la table: essais sur la cuisine au Moyen Âge et répertoire des manuscrits médiérvaux contenant des recettes culinaires, Presses de l'Université de Montreal, Montreal, 29-38.

Hubert, A. (2000), “Cuisine et politique: le plat national existe-t-il?”, Révue des sciences sociales. Révolution dans les cuisines 27: 9-11.

Laurioux, B. (1997), "L'histoire de la cuisine: problèmes, sources et méthodes", in S. Cavaciocchi (ed.), Alimentazione e nutrizione, sec. XIII-XVIII (Prato, 22-27 Aprile 1996), Le Monnier, Firenze, 463-487.

Laurioux, B. (2006), “Cuisine et médecine au Moyen Âge: alliées ou ennemies?”, Cabiers de recherches médiévales et humanistes, n. 13 spécial (La Figure de Jules César au Moyen Âge et à la Renaissance): 223-238.

Leroyer, Ch. (2007), La châtaigne en Périgord, fruit des temps et des hommes, La Lauze, Périgueux. Mane, P. (2006), Le travail à la campagne au Moyen Âge. Étude iconographique, Picard, Paris. Marques, A. H. O. (1971), "Inquirições”, in J. Serrão (ed.), Dicionário de História de Portugal, vol. II, Iniciativas Editoriais, Porto, 552-554.

Marques, A. H. O. (1971), “Pesos e Medidas”, in J. Serrão (ed.), Dicionário de História de Portugal, vol. III, Iniciativas Editoriais, Porto, 371-374.

Meyzie, Ph. (2010), "Une cuisine d'Europe centrale à la mode française. Mythes et réalités (XVIe-milieu XIXe siècles)", in O. Chaline, J. Dumanowski, M. Figeac (eds.), Le rayonnement culturel de la France en Europe centrale du XVIe siècle à nos jours, Armand Colin, Paris, 181-196.

Montanari, M. (1988), “Cibo e salute”, in Alimentazione e cultura nel Medioevo, Laterza, Roma, 206-220.

Montanari, M. (2004), Il cibo come cultura, Laterza, Roma-Bari.

Montanari, M. (2012), Gusti del Medioevo. I prodotti, la cucina, la távola, Laterza, Roma-Bari.

Moreau, M. (2005), "Berta Júdice Rosa Limpo", in Z. O. Castro, J. Esteves (ed.), Dicionário no Feminino (séculos $X I X-X X$ ), Livros Horizonte, Lisboa, 177.

Nutton, V. (2004), Ancient Medicine, Routledge, London.

Ornellas e Castro, I. (2015), O Livro de Cozinha de Apício. Um breviário do gosto imperial romano. Introdução, tradução e comentário, Relógio d’Água, Lisboa.

Ornellas e Castro, I., Braga, I. D. (2014), "Una escritura femenina diferente: los manuscritos culinarios conventuales portugueses de la Edad Moderna”, in N. Baranda Leturio, M. C. Marín Pina (eds.), Letras en la Celda. Cultura Escrita de los Conventos Femeninos en la España Moderna, Vervuert, Madrid, 439-455.

Pereira, A. M., Pericão, M. G. (2015), Do comer e do falar... Vocabulário gastronómico, Relógio d'Água, Lisboa.

Pilcher, J. M. (1997), "Recipes for Patria: Cuisine, Gender, and Nation in 
Um doce e nutritivo fruto: a castanha na história da alimentação e da gastronomia portuguesas

Nineteenth-Century Mexico", in A. L. Bower (ed.), Recipes for Reading: Community Cookbooks, Stories, Histories, University of Massachusetts Press, Amherst, 200-215.

Powell, O. (2003), Galen. On the properties of Foodstuffs, foreword by John Wilkins, Cambridge University Press, Cambridge.

Quitério, J. (1987), Livro de bem comer. Crónicas de Gastronomia, Assírio e Alvim, Lisboa.

Rao, R. (2013), "Una civiltà del castagno: uomini e boschi nell'Appennino lígurepiemontese durante l'apogeo del Medioevo (secoli XII-metà XIV)", Archivio storico italiano 171: 207-227.

Ruggiu, F.-J. (2007), “Quelques réflexions sur l'histoire comparée et sur les théories des interactions culturelles”, in J.-P. Genet, F.-J. Ruggiu (eds.), Les idées passent-elles la Manche? Savoirs, représentations, Pratiques (France-Angleterre, $X^{e}-X X^{e}$ siècles), Presses de l'Université de Paris-Sorbonne, Paris, 379-393.

Sampaio, A. F. (1939), Volúpia, a Nona Arte: a Gastronomia, Livraria Simões Lopes, Porto.

Serôdio, C. et al. (eds.) (2013), Ovos molles de Aveiro: 500 anos, Associação de Produtores de Ovos Moles de Aveiro, Aveiro.

Scholliers, P. (2001), "Meals, food narratives and sentiments of belonging in past and present", in P. Scholliers (ed.), Food, drink and identity: cooking, eating and drinking in Europe since the Middle Ages, Berg, Oxford, 3-22.

Scully, T. (1995a), The Art of Cookery in the Middle Ages, Boydell Press, Woodbridge.

Scully, T. (1995b), "Tempering Medieval Food”, in M. W. Adamson (ed.), Food in the Middle Ages: a Book of Essays, Garland, New York, 3-23.

Soares, C. (2012), “Arte culinária em Xenofonte, Platão e Aristóteles”, in C. Soares, P. B. Dias (eds.), Contributos para a História da Alimentação na Antiguidade, Imprensa da Universidade de Coimbra, Coimbra, 35-47.

Soares, C. (2018a), "A Universidade de Coimbra no cardápio da Cosinha Portugueza de 1902: uma história por contar", in C. Soares (ed.), BiblioAlimentaria: alimentação, saúde e Sociabilidade à mesa no acervo bibliográfico da Universidade de Coimbra, Imprensa da Universidade de Coimbra, Coimbra, 158-169.

Soares, C. (2018b), “Mesas terapêuticas e mesas saudáveis: Platão em diálogo com a literatura médica e gastronómica”, Archai 23: 229-264.

Sobral, J. M. (2007), "Nacionalismo culinário, culinária e classe. A cozinha portuguesa da obscuridade à consagração (séculos XIX-XX)”, RURIS 1.2: 13-52.

Sobral, J. M. (2014a), "The high and the low in the making of a Portuguese national cuisine in the nineteenth and twentieth centuries", in J. Klein, A. Murcott (eds.), Food consumption in global perspective: essays in the anthropology of food in honour of Jack Goody, Palgrave Macmillan, Basingstoke, 108-134.

Sobral, J. M. (2014b), "The country, the nation, and the region in representations of Portuguese food and cuisine", in N. Domingos, J. M. Sobral, H. G. West (eds.), Food between the country and the city: ethnographies of a changing global foodscape, Bloomsbury, London, 145-160.

Vasconcelos, C. B. M., Bennett, R. N., Rosa, E. A. S., Ferreira-Cardoso, J. V. (2010), "Composition of European chestnut (Castanea sativa Mill.) and association with 
health effects: fresh and processed products", Journal of the Science of Food and Agriculture 90.10: 1578-1589.

Vaz, F. C., Tereso, J. P. (2012), "Estudo antracológico do compartimento 1, setor A-2008 de Monte Mozinho”, Estudos do Quaternário 8: 38-47.

Vaz, F. C., Tereso, J. P., Lemos, P. P., Abranches, P. B. (2016a), "Estudo arqueobotânico do Castro de Cidadelhe (Mesão Frio): resultados preliminares”, Estudos do Quaternário 15: 59-69.

Vaz, F. C., Martín-Seijo, M., Carneiro, S., Tereso, J. P. (2016b), "Waterlogged plant remains from the Roman healing spa of Aquae Flaviae (Chaves, Portugal): utilitarian objects, timber, fruits and seeds", Quaternary International 404 (A): 86-103.

Viterbo, J. S. R. (1966), Elucidário, ed. crítica de M. Fiúza, vol. II, Livraria Civilização, Porto-Lisboa. 